\title{
Contribuição à Metodologia para Determinação da Pressão de Expansão em Solos e Rochas
}

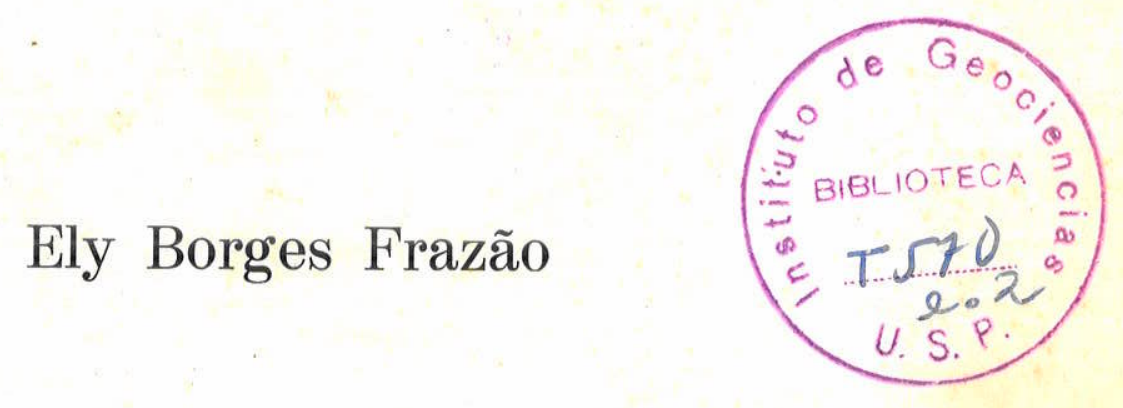

Dissertação de Mestrado apresentada ao Instituto de Geociências da Universidade de São Paulo

Orientador: Prof. Dr. José Eduardo S. Farjallat

São Paulo

1981 
CONTRIBUIÇĀO Ā METODOLOGIA PARA DETERMINAÇĀO

DA PRESSÃO DE EXPANSÃO EM SOLOS E ROCHAS

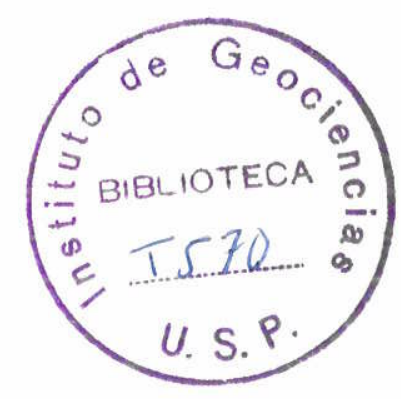

ELY BORGES FRAZAO

\begin{abstract}
Dissertação de Mestrado
apresentada ao Instituto

de Geociências da Unị

versidade de São Paulo
\end{abstract}

Orientador: Prof. Dr. Josē Eduardo S. Farjallat

São Paulo

1981

DEDALUS - Acervo - IGC

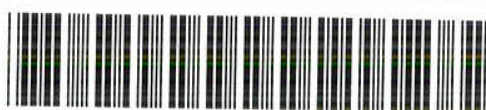

30900004943 


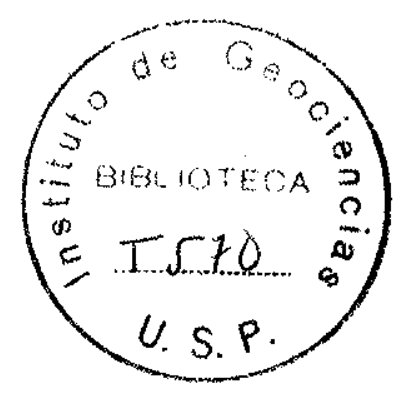

A

Lilian, minha mulher; ao Fabio e à Luciana; meus filhos. 


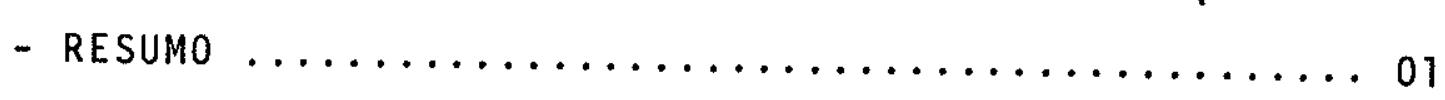

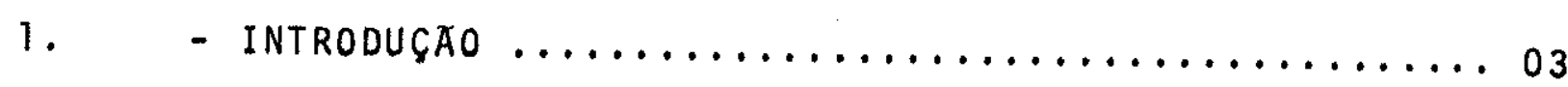

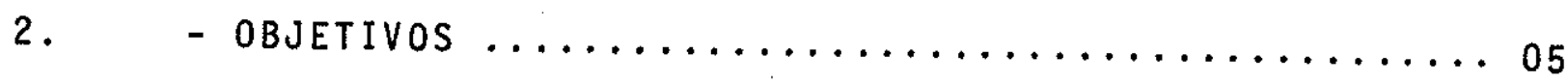

3. - 0 FENOMENO DA EXPANSAO $\ldots \ldots \ldots \ldots \ldots \ldots \ldots \ldots \ldots \ldots$

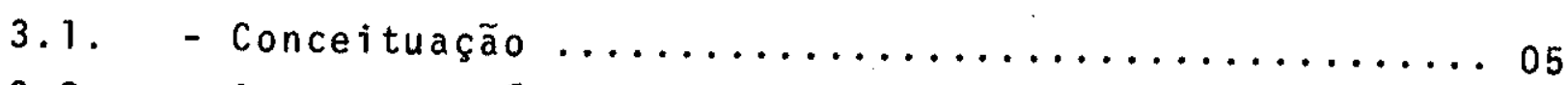

3.2. - Aspectos Teöricos do Fenōmeno .............. 06

3.3. - Fatores que Influenciam a Expansão ............ 08

4. - METODOLOGIAS UTILIZADAS NA AVALIAÇAO DA EXPANSIBILI

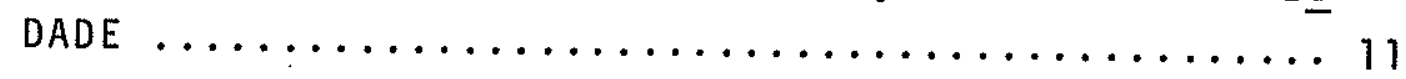

4.1. - Critērio Baseado na Composição Mineralögica ...... 11

4.2. - Critério Baseado nos Limites de Consistência ..... 12

4.3. - Critērios Baseados em Ensaios de Expansão ........ 14

4.4. - Critērios Baseados em Ensaios de Pressão de Expan são .................................... 15

5. - APARELHAGENS UTILIZADAS PARA DETERMINAÇAO DA EXPANSAOO E DA PRESSAOO DE EXPANSAOO CONSTANTES DA LITERATU

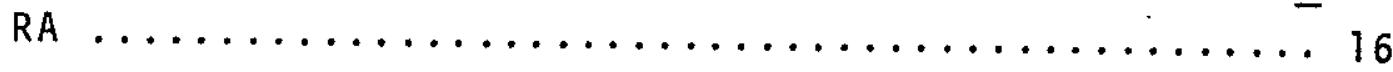

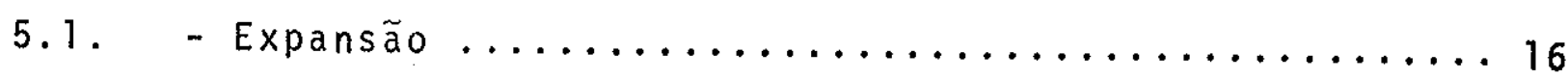

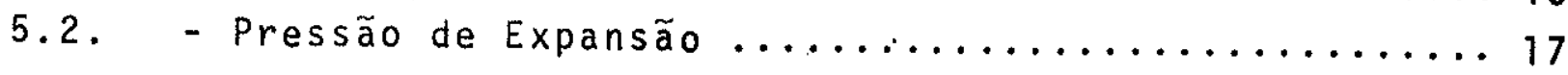

6. - METODOLOGIA E APARELHAGEM ADOTADOS PARA MENSURAÇAO

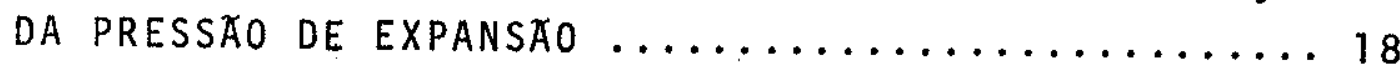

6.1. - Método de Ensaio "A Volume Constante" ......... 18

6.2. - Aparelhagem ...................... 18

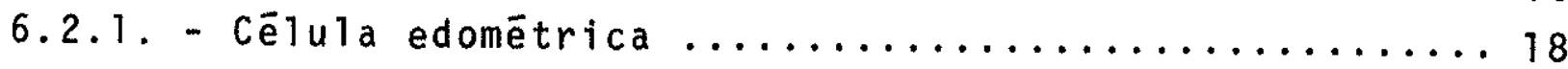

6.2 .2 . Prensa ........................... 19

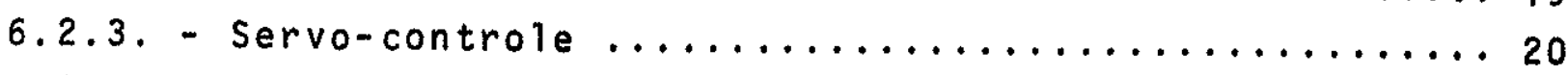

6.2 .4 . Registrador ..................... 23

6.3. - Calibração do sistema prensa/servo-controle/regis -

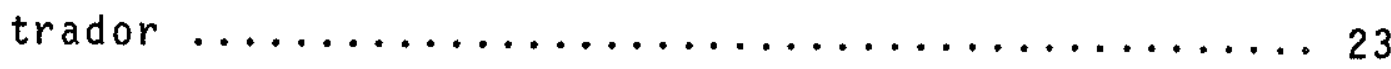

6.3 .1 - Calibração dos transdutores ................ 24 
6.3.2. - Calibração do registrador ................. 24

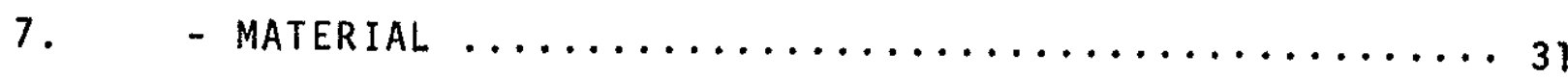

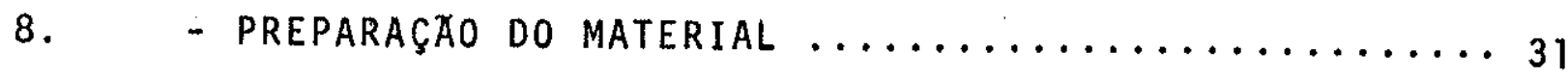

9. - CARACTERIZAÇAO do MATERIAL ................. 31

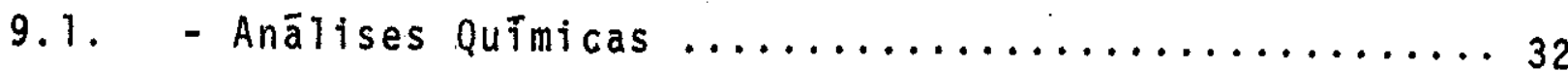

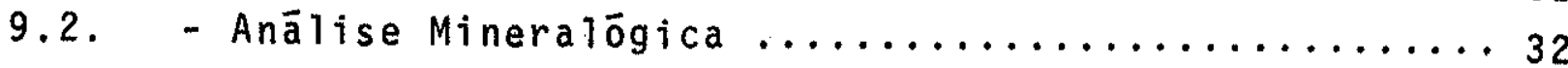

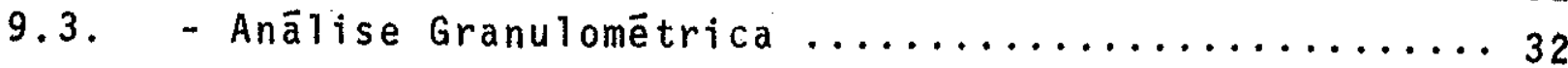

9.4. - Determinação do Peso Especifico Real ............ 33

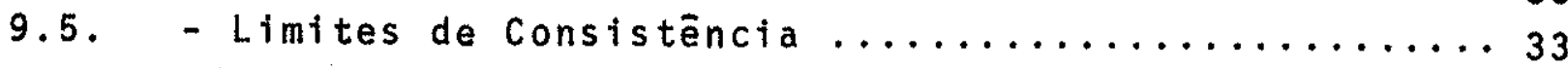

9.6. - Expansão Livre ....................... 33

10. - DISCUSSAO DOS RESULTADOS DA CARACTERIZAÇAO DA AMOSTRA $\ldots \ldots \ldots \ldots \ldots \ldots \ldots \ldots \ldots \ldots \ldots \ldots \ldots \ldots \ldots \ldots \ldots \ldots \ldots \ldots \ldots \ldots \ldots \ldots$

11. DETERMINAÇAO dOS PARAMETROS DE ENSAIO DE PRESSAO

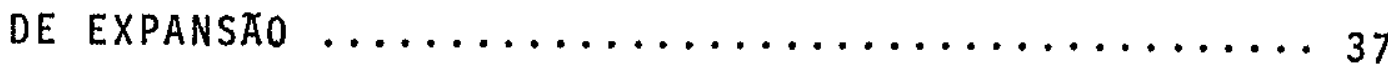

11.1. - Preparação dos Corpos de Prova ................ 37

11.2. - Teor de Umidade ...................... 37

11.2.1. - Procedimento operacional ................ 37

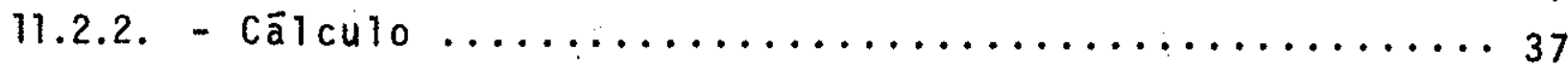

11.3. - Determinação da Densidade do Corpo de Prova ...... 38

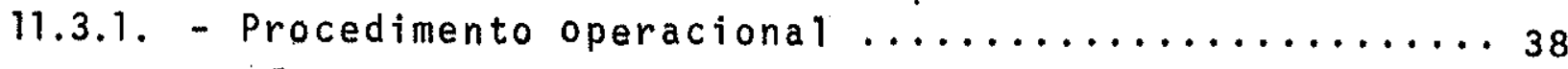

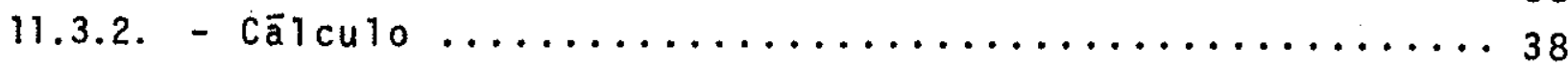

11.4. - Massa .................................. 39

12. - ENSAIO DE PRESSAO DE EXPANSAO $\ldots \ldots \ldots \ldots \ldots \ldots \ldots$

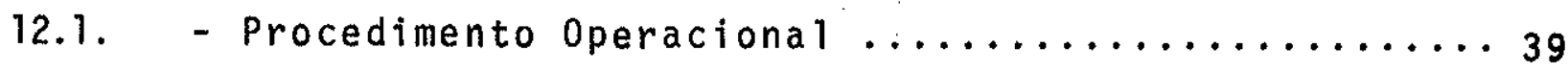

12.2. - Cälculo ............................ 40

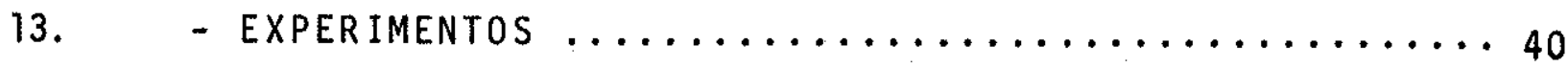

13.1. - Verificação da Influencia da Massa na Pressão de Ex

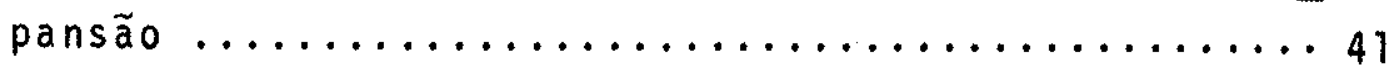

13.1.1. - Procedimentos operacionais $\ldots \ldots \ldots \ldots \ldots \ldots \ldots \ldots 41$

13.1.2. - Resultados ........................... 42

13.1.3. - Correlação e discussão dos resultados $\ldots \ldots \ldots \ldots 42$ 
13.1.4. - Conclusões parciais .................... 44

13.2. - Verificação da Influência da Densidade Seca na Pres

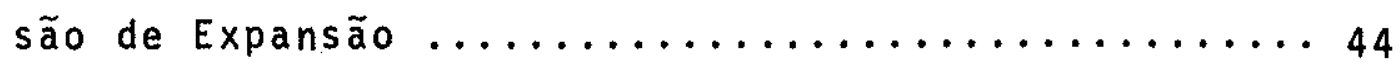

13.2.1. - Procedimentos operacionais $\ldots \ldots \ldots \ldots \ldots \ldots \ldots \ldots 44$

13.2.2. - Resultados ........................ 45

13.2.3. - Correlação e discussão dos resultados ......... 45

13.2.4. - Conclusões parciais ..................... 46

13.3. - Verificação da Influencia do Teor de Umidade Ini -

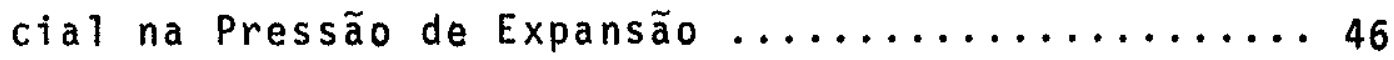

13.3.1. - Procedimentos operacionais $\ldots \ldots \ldots \ldots \ldots \ldots \ldots \ldots \ldots$

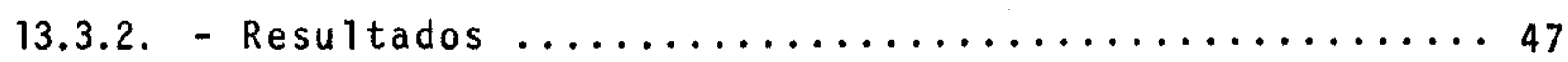

13.3.3. - Correlą̧ão e discussão dos resultados .......... 47

13.3.4. - Conclusões parciais ....................... 48

13.4. - Estudo Comparativo do Desempenho do Sistema Adotado Frente a um Sistema Convencional .............. 49

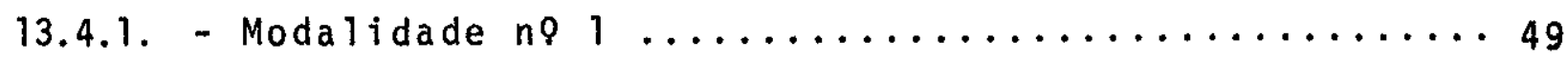

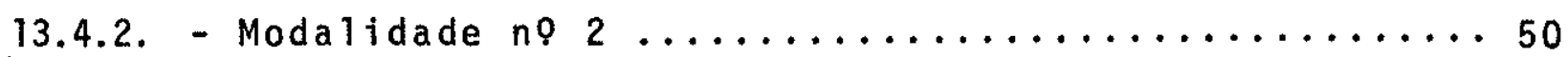

13.4.3. - Ensaios "a volume constante" com as amostras de are nitos silto-argilosos .................... 52

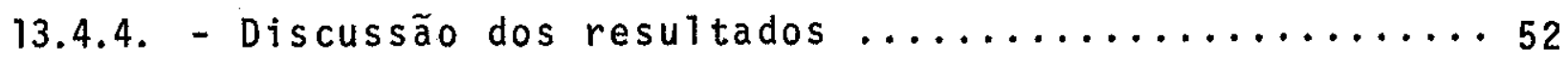

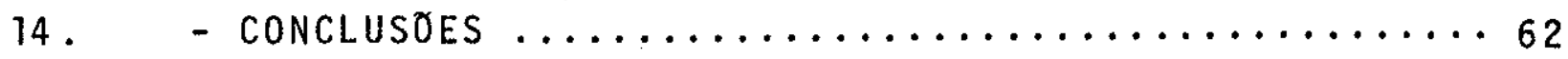

- AgRAdecimentos ........................... 64

- BIBLIOGRAFia ......................... 66 
Figuras

01 - Corte esquemātico da cēlula edomëtrica .......... 26

02 - Vista frontal da prensa utilizada na determinação da

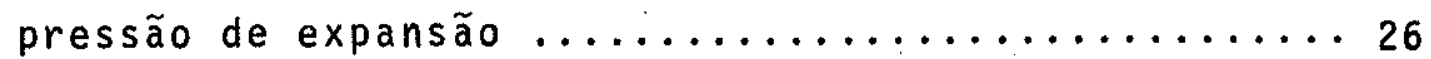

03 - Detalhe da prensa com distribuição dos elementos de

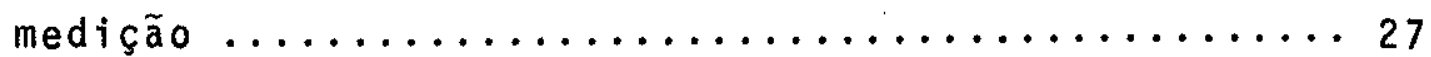

04 - Diagrama de blocos do servo-controle ........... 27

05 - Detalhe do circuito elétrico dos transdutores .....2 28

06 - Distribuição dos valores do transdutor de carga em função do relógio comparador de carga ............ 29

07 - Distribuição dos dados da calibração do registrador em função do relógio comparador de carga ......... 30

08 - Resultados da anālise mineralógica da amostra de ar-

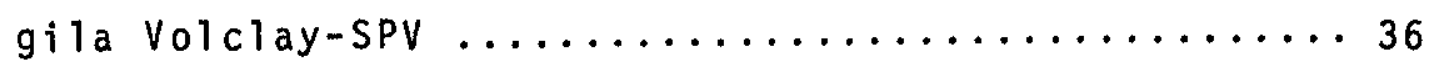

09 - Distribuição dos valores das frequencias em porcenta gem das densidades secas ................... 54

10 - Distribuição dos valores de pressão de expansão em função dos de massa ...................... 56

11 - Distribuição dos valores de pressão de expansão em função dos de umidade final $\ldots \ldots \ldots \ldots \ldots \ldots \ldots . \ldots 6$

12 - Distribuição dos valores de umidade final em função

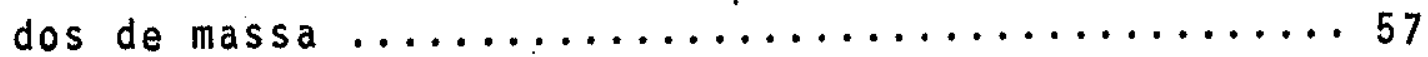

13 - Distribuição dos valores de pressão de expansão em função dos de densidade seca ................. 58

14 - Distribuição dos valores de pressão de expansão em função dos de umidade final $\ldots \ldots \ldots \ldots \ldots \ldots \ldots . \ldots . \ldots$

15 - Distribuição dos valores de umidade final em função dos de densidade seca ..................... 59

16 - Distribuição dos valores de pressão de expansão em função dos de umidade inicial ...............60 60

17 - Distribuição dos resultados do ensaio de pressão de expansão de acordo com a modalidade no $1 \ldots \ldots \ldots .60$

18 - Distribuição dos resultados do ensaio de pressão de expansão segundo a modalidade $n$ $92 \ldots \ldots \ldots \ldots \ldots 61$ 
01 - Resultados da calibração do transdutor de carga em função do relógio comparador de carga ........... 28

02 - Resultados da calibração do registrador em função do

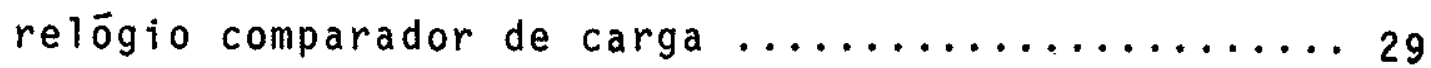

03 - Composição química da amostra de argila Volclay-SPV. 35

04 - Capacidade de troca de cātions e cātions trocāveis da amostra de argila Volclay-SPV ................ 35

05 - Algumas propriedades físicas da amostra de argila

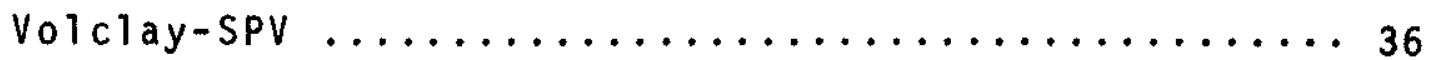

06 - Frequências em nümero e em porcentagem das densida des secas .............................. 54

07 - Resultados da verificação da influēncia da massa na pressão de expansão ...................... 55

08 - Resultados da verificação da influência da densidade seca na pressão de expansão ............... 57

09 - Resultados da verificação da influência da umidade nicial na pressão de expansão ............... 59

10 - Resultados dos ensaios de pressão de expansão nos a-

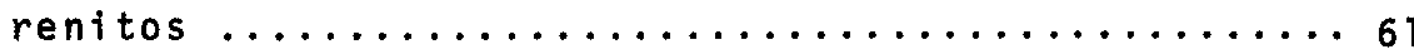


A expansão de solos e de rochas, por absorção de āgua, e a pressão manifestada no curso da expansão têm causado danos a obras civis em vārias regiões do Globo e, por esta razão, têm si do objeto de atenção de geōlogos e engenheiros que lidam na construção civil.

Existem diversos meios para avaliação e determinação da ex pansão e da pressão de expansão, sendo que esta é de maior im portāncia na prätica da Engenharia Civil.

Para a determinação do valor da pressão de expansão de um solo, ou de uma rocha, é desejāvel um método e um processo de ensaio que sejam o mais simples, räpido e exato possivel e que melhor reflitam as situações pelas quais passarā o material com - qual, ou sobre o qual, se edificarā uma obra civil.

Escolneu-se, neste estudo, o mëtodo "a volume constante", com monitoração automätica dos ensaios, por ser o que mais atende aos requisitos acima citados.

A manutenção da constāncia de volume das amostras foi al cançada atravēs da utilização de um transdutor que, colocado en tre os pratos de uma prensa motorizada, envia sinais a um circuito eletrónico que aciona o motor da prensa para aplicar ou retirar carga quando a amostra, entre os pratos, tende a expandir ou a contrair, respectivamente. Os valores das cargas são lidos em um relögio comparador ou num registrador, onde, a partir de sinais enviados por outro transdutor, tem-se os registros convertidos diretamente para valores de pressão.

Utilizando-se de uma amostra de uma argila denominada Volclay-SPV, executaram-se ensaios visando conhecer a influência da massa, da densidade seca e da umidade inicial, de corpos de prova, na pressão de expansão.

Para comparar o desempenho desse sistema realizaram-se ensaios, tambëm com a argila Volclay-SPV, de acordo com um método em que se permitiu a expansão dos corpos de prova sob trés valo res prē-fixados de pressão, os quais foram aplicados através de uma prensa de alavancas. Realizaram-se, tambëm, ensaios sobre 
quatro amostras de arenitos "a volume constante" e com monitora ção automática e, de acordo com o mesmo mētodo em que se permite a expansão dos corpos de prova, mas sob pressões com valores que obedecem a escala de uma progressão geomētrica, como nos en saios rotineiros de adensamento. sões:

Este estudo permitiu chegar às seguintes principais conclu

1) quanto maior a massa dos corpos de prova, maior foi a pressão de expansão; a influência foi maior na faixa de 3 a $15 \mathrm{~g}$ e decresceu a partir desta;

2) quanto maior a densidade seca dos corpos de prova, maior foi a pressão de expansão;

3) quanto maior a umidade inicial dos corpos de prova, menor foì a pressão de expansão;

4) o sistema de monitoração automätica de acordo com o mëtodo "a volume constante" foi mais exato e mais räpido que o sistema convencional escolhido para comparação. 


\section{INTRODUÇAO}

0 fenōmeno da variação volumētrica em solos e em rochas, devido a modificações em seu teor em āgua, tem merecido atenção de pesquisadores no mundo inteiro. Is to é demostrado por inūmeros trabalhos sobre o assunto.

Por variação volumētrica entendem-se a expansão e a contra ção devido ao ganho e à perda de āgua, respectivamente. Pode ma nifestar-se macroscopica ou microscopicamente e ser, em alguns casos, mensurāvel direta e, em outros, indiretamente.

Se por um lado a variação de volume pela variação de umida de é desejāvel, como, por exemplo, em argilas empregadas como fluỉdo de perfuração de poços de petrōleo, por outro, ē nociva, quando se trata de materiais com os quais ou sobre os quais se edifica uma obra civil.

Apesar de o fenōmeno ser bem conhecido, os mecanismos que - regem não foram ainda bem compreendidos, malgrado o empenho de pesquisadores de diferentes especialidades na sua elucidação. Isto ē constatado pela diversidade de enfoques e pelos diferentes niveis de tratamento dados ao assunto. Chen (1975) ressalta, contudo, que grandes progressos foram alcançados nos ūitimos 20 anos, apesar de certos danos a obras civis, nos EUA, terem sido admitidos como consequência do fenömeno da expansão, jā em fins da dëcada de 30.

A previsão da variação volumētrica de um substrato geolōg co assume, em algumas āreas do Globo, importāncia relevante para a Engenharia Civil. E o caso de certas regiões da Austrālia, Canadā. India, Israel, Mēxico, Africa do Sul, Espanha e Venezue la, dentre outros paises, onde o comportamento dos solos expansivos tem causado sērios prejuízos econômicos, decorrentes das danificações causadas nas obras civis, pela instabilização provocada em suas fundações (Chen, 1975 e Horta da Silva, 1971 e 1975 ). 
Sobre problemas causados em galerias, destacam-se os traba Thos de Bjerrum, Brekke, Moum e Selmer-01sen (1964) e Brekke (1965). Relatam desabamentos provocados pela presença de montmo rilonita, durante e apōs a perfuração de tūneis, cortando zonas cisalhadas de maciços rochosos prē-cambrianos e paleozóicos da Noruega. Thenoz, Farran e Capdecomme (1966) citam acidentes o corridos em tūneis perfurados em granitos e gnaisses, na França, onde alēm de ocorrer desabamentos apōs perfuraçōes dos tūneis. houve rompimento do revestimento de concreto, pela expansão de montmorilonitas, em certos trechos.

No Brasil, contudo, poucos são os relatos sobre materiais naturais expansivos, se comparado com os países citados, e ra ros são os estudos mais detalhados sobre o processo da expansão. Isto se deve, talvez, $\bar{a}$, ainda, relativamente pequena ocupação urbana nas āreas onde ocorrem solos jā conhecidos como expansivos e à distribuição relativamente restrita dos mesmos em nosso País. Apesar disso, a tgumas consequéncias danosas, devido à pre sença de minerais expansivos em solos e rochas, jā foram experi mentadas pela Engenharia Civil brasileira, em algumas obras. Ruiz (1963), Farjallat (1969), e Farjallat, Montezzo e Ratti (1972), abordaram a influência da expansibilidade no processo de desagregação de rochas basāiticas, contendo esmectitas, com vistas ao seu desempenho como material de construção. Fleury (1978), estudou a expansibilidade de alguns arenitos silto-argi losos do Grupo Tubarão a partir do desempenho insatisfatörio apresentado por estes materiais nas fundações de uma obra civil em Sumarē, Estado de São Paulo.

Do ponto de vista prático, tão importante quanto o entendi mento do fenōmeno, è existirem metodologias e instrumentações a dequadas à sua quantificação.

Este trabalho pretende ser uma contribuição à metodologia e ao processo de mensuração da pressão de expansão de solos e de rochas em contato com āgua, atravēs da proposição de um sistema que permite medir a pressão de expansão, a volume constante. Este sistema consiste, basicamente, de uma prensa, de um servo-controle e de um registrador; permite a monitoração automätica dos ensaios e registro continuo dos resultados. 


\section{OBJETIVOS}

0 presente trabatho foi estruturado para atingir dois obje tivos bāsicos:

a) investigar a influência de alguns parāmetros físicos e quīmicos na pressão de expansão, atravēs de comparação dos re sultados obtidos com os constantes da literatura, fornecidos por equipamentos e métodos convencionais ou não, e

b) testar o desempenho do sistema "prensa/servo-controle", de acordo com o método a volume constante, frente a metodolo gias e equipamentos convencionais.

\section{FENOMENO DA EXPANSAO}

0 fenômeno da expansão em um material natural depende de diversos fatores que serão abordados a seguir.

\subsection{CONCEITUAÇAO}

De um modo geral, denomina-se expansão ou inchamento de um solo ou de uma rocha, toda evolução acompanhada de aumento de volume (De Lamballerie, 1962; Karalis, 1971). A capacidade ou potencjalidade à expansão ē denominada por Brekke (1965), de ex pansibilidade.

Se um corpo de prova de um solo, sujeito a uma determinada carga, é posto em contato com água, quando se suprime esta carga haverā um aumento de volume concomitante ao aumento de seu teor em água. A ägua, por sua vez, pode adentrar o corpo de pro va por absorção e por adsorção (White, 1958).

Todos os solos têm capacidade de aumentar de volume em pre sença de ägua. Dependendo de sua composição mineralógica, entre tanto, a amplitude do fenōmeno variarā amplamente. Se o corpo de prova, nas condições citadas, for de um solo grosseiro constituido, por exemplo, de quartzo e mica, sua expansão será pe quena e serā devida, principalmente, à restituição elāstica das particulas (principalmente das de mica). Se, por outro lado, o corpo de prova for, por exemplo, de um solo fino argiloso con tendo esmectita, a expansão serā considerável. Neste caso alēm da restituição elástica, contribuirā na expansão o aumento pro- 
gressivo das camadas de ägua entre as partículas e dentro das prōprias partículas de argila (De Lamballerie, 1962).

0 fato das esmectitas expandirem em presença de āgua ē relativamente bem conhecido. Dependendo do tipo de esmectita, 0 volume final atingido serā de atē 30 vezes o inicial (Delarue, 1953, in De Lamballerie, 1962). Mielenz e King (1955, in Grim, 1962) apresentam dados ilustrativos quando comparam valores de expansão entre esmectitas e outros tipos de argilo-minerais.

As considerações feitas para os solos, atravēs dos exemplos acima mencionados, são vālidas tambēm para as rochas sedimentares e cristalinas alteradas, contendo esmectitas.

\subsection{ASPECTOS TEORICOS DO FENOMENO}

A expansão em solos e rochas em contato com āgua, tem sido estudada por numerosos pesquisadores, e teorias diversificadas têm evoluido para interpretar o fenōmeno. Pode-se citar a teo ria da capilaridade, a teoria osmötica, dentre outras (De Lamballerie, 1962).

Devido a controvērsias ainda existentes sobre quais os reais mecanismos da expansão e tambēm por fugir do escopo desse traba iho, passaremos em revista apenas algumas idéias a respeito do assunto.

As teorias existentes caminham para uma explicação quase satisfatōria da expansão; nenhuma delas, porēm, isoladamente, explica as diferentes constatações do fenōmeno.

A teoria da capilaridade, que $\bar{e}$ a mais utilizada, admite que no curso da dessecação de um solo um estado de tensões se desenvolve na àgua intersticial, onde a intensidade aumenta ä medida que o teor em água diminui. Para o solo tudo se passa co mo se houvesse uma tensão externa, de valor absoluto igual ä tensão interna, que nasce no seio do líquido, mas de sentido conträrio. Disso resulta uma contração do material. Se, por outro lado, o teor de āgua aumentar, tenderā a haver uma anulação da tensão intersticial, com consequente separação das partĩcu las, manifestando-se num aumento de volume que é a expansão. Se essa expansão for impedida, haverá o desenvolvimento, por parte do solo, de uma pressão que é denominada de pressão de expansão. 
A teoria da capilaridade fornece uma abordagem quantitativa do fenömeno, pois permite conhecer os parāmetros físicos colocados em jogo, sendo que a pressão capilar pode ser determina da em experimentos de laboratōrio (De Lamballerie, 1962).

Kulchitskij (1962), por sua vez, considera a teoria da capilaridade insuficiente para explicar o fenömeno da expansão, apesar de largamente utilizada. Menciona que a resolução de pro blemas complexos de construção civil sobre solos argilosos satú rados, exige um modelo que leve em conta as caracteristicas físico-quimicas das fases do sistema "argila-ägua-ions", assim co mo das soluções eletroliticas em contato com as lamelas dos argilo-minerais. Admite que durante a interação "āgua-minerais ar gilosos", apōs a dissociação iōnica na superfície da partīcula, hä o aparecimento de um certo nümero de centros de adsorção não equilibrados, do ponto de vista eletrostätico, que criam um campo elētrico. A intensidade de movimentos de cātions dissocia dos na sentido desse campo excederia a intensidade de movimento em sentido conträrio. Então, em torno da particula argilosa for mar-se-ia uma atmosfera de cātions que favoreceria a migração de molēculas de ägua na direção da partícula, como num processo osmōtico, criando uma pressão osmōtica na camada difusa, hidratada e ionizada da particula. Verwey e Overbeek (1948, in Didier, 1972), defendem tambëm esta concepção e enfatizam que a pressão osmōtica ē função da concentração de ĩons no plano interlamelar do argilo-mineral.

Kulchitskij sustenta esta concepção a partir de experimentos com osmōmetros com os quais simulou as situações vigentes num solo argiloso saturado. Conclui que para amostras remolda das, a pressão de expansão, ou seja, a pressão necessāria para que não haja expansão, ë igual à pressão osmōtica, e que para argilas naturalmente compactadas a pressão de expansão é igual a $40 \%$ da pressão osmötica.

Delarue (1953, in De Lamballerie, 1962), admitiu que a pressão de expansão de um material é iguàl à pressão de consoli dação que este suportou no curso de sua histöria geolögica e que seria, em valor absoluto, igual à pressão capilar desenvolvida no solo. Esta conclusão foi baseada em medidas de pressão 
de expansão, e pressão de consolidação, determinadas em laboratōrios, sobre argilas naturais, onde na maioria dos casos as pressões de expansão não diferiam em mais que $10 \%$ das pressões de consolidação.

A maioria dos trabalhos que tratam da expansão em solos e rochas ressaltam, contudo, a preponderāncia da influência mineralögica no processo.

\subsection{FATORES QUE INFLUENCIAM A EXPANSAOO}

Brekke (1965) agrupa os fatores intervenientes na expansão em fatores internos e externos. São internos aqueles ligados à natureza do solo, ou da rocha, e que definirão a possibilidade de haver expansão. São externos aqueles que definirão se aconte cerā a expansão e que características terā esse processo quando se efetivar.

os fatores internos são: tipo de argilo-mineral presente, quantidade de fração argila, tipo de cātion trocāvel do argilomineral, concentração de ions na fração argila, dimensões das particulas de argila, estrutura do argilo-mineral, teor de umidade e densidade seca no início do processo de expansão e existência, ou não, de cimentação diagenētica.

A esses fatores Holtz e Gibbs (1956, in Chen, 1974) acrescentam a constante dielëtrica da argila, a "atividade" da argi1a, o Indice de plasticidade e o limịte de contração.

os fatores externos, segundo Brekke (1965), são: possibili dade de acesso de ägua aos argilo-minerais, concentração e natu reza dos Tons dissolvidos na ägua e possibilidade de aumento de volume pela existência, ou não, de "contra-pressão" externa sobre a argila.

Holtz e Gibbs (1956, in Chen, 1975) e Seed, Woodward e Lundgren (1962) denominam esses fatores de "condições in situ", enumerando-os em: pressão de sobrecarga, duração da saturação ou grau de saturação, teor de umidade inicial, espessura do estrato expansivo e densidade seca.

os fatores internos podem ser analisados ao nível da parti cula e das relações entre as particulas. Se o argilo-mineral ē esmectitico, este traz consigo uma dada capacidade de troca de 
cātions (elevada) que permitirā uma dada concentração de cātions ao redor e dentro da particula. Se o cātion presente for, p.ex., - sōdio ou o lítio, a expansão será maior do que se, p.ex., for - cālcio ou o magnēsio, porque o sōdio e o tîtio atraem uma maior quantidade de molēculas de ägua que o cālcio ou o magnē sio.

Mielenz e King (1955, in Grim, 1962) apresentam resultados de expansão em diferentes tipos de argilo-minerais, em que uma montmorflontta, contendo sōdio como cätion trocāvel, mostrou a mentos relativos de volume da ordem de 1.400 a $1.600 \%$. Entre os diferentes tipos de argilo-minerais, os menores valores foram apresentados pelas caulinitas.

White (1958) efetuou ensaios de adsorção de āgua em dife rentes tipos de minerais, encontrando os maiores valores $(1.100$ a $1.200 \%$ de ägua adsorvida) para as montmorilonitas com alta capacidade de troca de cátions (CTC) e que tinham Na e Li como cātions trocāveis (CT). As caulinitas apresentaram valores cerca de 10 vezes menores.

Quanto ao teor em argila, Graft-Johnson, Bhatia e Yeboah (1974), estudando folhelhos argilosos, siltosos e arenosos, encontraram maiores valores de expansão para os argilosos ( $\approx 6 \%)$, médios para os siltosos $(\approx 3 \%)$ e menores para os arenosos $(\simeq 0,5 \%)$. A dimensão das partīculas estā, por sua vez, ligada à prōpria natureza dos argilo-minerais. Quanto menor a sua dimensão, maior serā a superficie específica, maior serä a capacidade de adsorção e, portanto, maior serä.:a expansão (Didier, 1972). No caso das esmectitas as dimensões das particulas encontram-se abaixo de 0,1 micron e a superfĩcie específica teörica $\bar{e}$ de $8 \times 10^{6} \mathrm{~cm}^{2} / \mathrm{g}$ (Grim, 1958$)$.

Ao nivel das relações interparticulares resultam as caracterīsticas de estrutura e de densidade seca, que têm um apreciă vel efeito na expansão e pressão de expansão. As partĩculas de argila podem se arranjar em estruturas diversificadas a partir do posicionamento de umas em relação às outras. Daĩ decorrem di ferentes estruturas de acordo com os posicionamentos "face-face", "canto-canto", "canto-face", etc. (Grim, 1958). Essas estrutu ras se formam em consequência da distribuição, ou densidade, de 
cargas na superfície das partículas, que geram atração e repulsão entre elas. Esses efeitos são ainda dependentes da natureza dos eletrölitos do meio. Resultam disso as estruturas ditas flo culadas ou dispersas (Lambe, 1958). Essas associações entre as particulas de argila, e entre estas e outras particulas do solo, são denominadas de microestruturas do solo. Kulkarni e Katti (1974) apontam a influēncia da microestrutura na expansão e pres são de expansão a partir do estabelecimento de modelos físicos baseados na relação espacial entre as partículas de um solo argiloso. Chegam a propor equações que, utilizando valores de cer tos parāmetros físicos do solo (teor em fração argila, indice de vazios, expansão e pressão de expansão), permitem calcular a expansão e a pressão de expansão de uma partícula individual do solo estudado.

As macroestruturas (laminações, estratificações e outras feições macroscōpicas), refletem, por sua vez, as condições de deposição e de compactação e tambēm influenciam a expansibilida de.

Quando se trata de amostras indeformadas, ou intactas, as expansões são mais elevadas quando perpendiculares às estrutu ras (Murayama e Yagi, 1966; Graft-Johnson, Bathia e Yeboah, 1974; Frazão, Mioto e Santos, 1976).

Para amostras remoldadas as estruturas parecem influenciar a expansão de modo diferente. Satyanarayna (1974), trabalhou com solos expansivos da India ("black cotton soils"), compactados estätica e dinamicamente, e ensaiados em diferentes dire ções em relação às direções de compactação. Concluiu que os valores de expansão e de pressão de expansão crescem da direção horizontal atē 45 e em relação a esta, para decrescer à medida que se aproxima da vertical. Cita, ainda, que os maiores valo res foram encontrados para os corpos compactados estaticamente e que, para qualquer dos processos de compactação usados, os maiores valores de expansão e pressão de expansão de deram para maiores densidades secas e menores teores de umidade iniciais.

Viajayvergia e Ghazzaly (1974) chegaram às mesmas conclu sões em relação à influēncia da densidade seca e teor de umidade inicial na expansão para solos expansivos dos EUA.Chen (1974 
e 1975), conclui ser a densidade seca o ünico parâmetro físico realmente significativo na pressão de expansão. Brackley (1974) chegou à mesma conclusão, trabalhando com indice de vazios de solos. Didier (1972) encontrou os maiores valores de pressão de expansão também para maiores densidades secas.

Com relação à cimentação diagenētica, Brekke (1965) e Didier (1972) ressaltam que esta diminui a expansão, pela rigidez que cria na estrutura do solo.

Quanto aos fatores externos, estes são fortemente dependen tes das características geológicas e climáticas e das ativida des antrōpicas. As características geológicas e climáticas respondem pela origem dos solos expansivos, pelo histórico das ten sões sofridas pelo estrato expansivo e pela flutuação do lençol freātico. As atividades antrópicas responderão pelas modifica ções causadas ao meio, principalmente pela implantação de obras civis de diferentes naturezas, que levam a alterações locais do equilibrio tenso-deformacional desse meio.

Dessa forma, a manifestação da expansão, ou o desenvolvi mento de pressões durante o processo, pode ou não acontecer. De penderão essencialmente do grau de conhecimento sobre a natureza dos materiais naturais sobre os quais ou com os quais se pre tende trabalhar, para que o desequilibrio imposto seja eliminado ou mantido sob controle.

4 METODOLOGIAS UTILIZADAS NA AVALIACAO DA EXPANSIBILIDADE CONS TANTES DA LITERATURA

A expansibilidade de um solo, ou de uma rocha, pode se ava liada a partir de diversos critērios. Baseiam-se na composição mineralōgica, no teor em fração argila, nos limites de consis tência e nos ensaios de expansão e de pressão de expansão (De Lamballerie, 1962 e Horta da Silva, 1975).

\subsection{CRITERIO BASEADO NA COMPOSIÇAO MINERALOGICA}

o critērio baseado na composição mineralögica assenta-se na natureza dos argilo-minerais presentes, com atenção especial na queles de rede cristalina expansiva, onde se destacam os do gru po das esmectitas. 
Associadas à natureza dos argilo-minerais, e do seu teor na fração argilosa, ocorrem propriedades que muitas vezes auxiliam na avaliação da expansibilidade, por exemplo, a capacidade de troca de cätios (CTC), a quantidade e os tipos de cätions tro cäveis (CT), etc.

Apesar da CTC apresentar-se com faixas de valores mais ou menos constantes para cada tipo de argilo-mineral (Grim, 1958 e 1962), a mesma pode ser utilizada como parāmetro auxiliar na avaliação da expansibilidade, por promover maior ou menor concen tração de cātions trocāveis na fração argila.

A natureza e o teor em cätions têm influência marcante na expansão, sendo maior, p.ex. para $\mathrm{Na}$ e $\mathrm{Li}$ do que para $\mathrm{Ca}$ e Mg. Fink et al, 1971 (in Horta da Silva, 1975), verificou que a expansão $\vec{e}$ função da porcentagem de sōdio trocāvel, que denominou de ESP (exchange sodium percentage). Foi determinada pela relação södio trocāvel/CTC, chegando a uma escala de valores em que ESP $>50 \%$ definem solos muito expansivos, $10 \%<$ ESP $<50 \%$, moderadamente expansivos e ESP>10\%, pouco expansivos.

Basu e Arulanandan (1974), tendo em conta que os solos a presentam constantes dielëtricas capazes de serem mensurāveis, propuseram um mētodo para determinação da dispersão dielétrica de solos. Compararam os valores da dispersão dielëtrica obtidos, com o äbaco de "atividade" de Skempton (1953) e de Seed, Woodward e Lundgren (1962), concluindo que dois dos principais fatores que controlam as propriedades dos solos (natureza e teor de argila) são os que mais afetam a quantidade da disper são dielëtrica. Considera esse processo como mais conveniente, porque não afeta os parämetros ligados à estrutura dos solos.

\subsection{CRITERIO BASEADO NOS LIMITES DE CONSISTENCIA}

No critērio baseado nos limites de consistência analisa-se a expansibilidade a partir dos valores dos limites da plasticidade (LP), de liquidez (LL), de contração (LC) e o îndice de plasticidade (IP).

A composição mineralögica serve como propriedade îndice, permitindo inferir se um solo $\vec{e}$ passivel ou não de apresentar ex panção apreciāvel, enquanto os valores de limites de consistên- 
cia permitem uma avaliação quantitativa de potencialidade de ex pansão.

Jantey e Brink (1952, in Horta da Silva, 1975) preconiza ram serem expansivos solos com $L L>30 \%$, IP $>12 \%$ e $L C>8 \%$.

Skempton (1953, in Grim, 1962) propōs o conceito de "ativi dade" (A) que consiste em relacionar o IP com o teor em particu las <2um classificando os solos em inativos, normais e ativos para classes de valores entre 0,5 e 2 .

Van der Merwe (1964, in Horta da Silva, 1975) compartimentou os solos em graus de potencialidade à expansão, relacionando valores de "atividade" de Skempton, para substratos geologicos divididos em camadas de propriedades idēnticas e a diferentes profundidades. Obteve um ābaco onde são definidas äreas 1 imitadas por valores de atividade de $0,5,1$ e 2 , para graus de potencialidade à expansão baixo, mëdio, elevado e muito elevado, nesta ordem.

Holtz e Gibbs (1956) afirmaram que IP e LL são üteis para determinar caracteristicas de expansibilidade de argilas.

Segundo Seed, Woodward e Lundgren (1962) apenas o IP, isoladamente, pode ser usado como indicação da expansibilidade.

Altmeyer (1955, in Chen, 1975) sugere o limite de contra ção e a contração linear para determinação do potencial de ex pansão, em que, de acordo com escala de valores desses dois indices, classifica os solos em graus de expansão denominados de crîtico, moderado e não crîtico.

Seed, Woodward e Lundgren (1962) estabeleceram experimen talmente correlações entre potencial de expansão (S), teor em fração argila (C) e indice de "atividade" (A), a partir de amos tras preparadas artificialmente, chegando a classificar os graus de expansão em: baixo, mëdio, alto e muito alto, para diferentes classes de valores de $S$.

Viajayvergia e Ghazzaly (1974), propõem a relação entre o teor de umidade inicial e limite de liquidez para avaliação da expansão, denominando essa relação de indice de expansão $\left(I_{S}=W / L L\right)$. 


\subsection{CRITERIOS BASEADOS EM ENSAIOS DE EXPANSAO}

Nos ensaios de expansão, procura-se medir as variações de volume do material, com ou sem sobrecarga imposta a ele.

Dentre estes o mais simples è o proposto por Foster ( in Zandonadi e Santos, 1972) denominado de teste de inchamento ou de expansão livre. Consiste em mergulhar $1 \mathrm{~g}$ do material, na forma de pō, em uma proveta graduada com capacidade de $100 \mathrm{ml}$, com ägua destilada, e ler o volume apresentado, apōs $24 \mathrm{~h}$. Thenoz, Farran e Capdecomme (1966) e Chen (1975) citam um processo seme Thante ao descrito acima, em que os resultados são apresentados em porcentagem a partir da diferença entre o volume inicial, se co, e o volume final, apōs a imersão em āgua.

Chen (1975) cita um procedimento para a determinação do po tencial de expansão que consiste em medir a variação de volume de um corpo de prova, confinado lateralmente, com densidade māxima obtida por compactação ao ōtimo de umidade, apōs embebição em àgua.

Lambe (1960, in Chen, 1975), desenvolveu um processo para medir o potencial da mudança de volume. Neste processo, uma a mostra, confinada lateralmente, prê-compactada, com sobrecarga, e à qual é fornecida ägua, è impedida de expandir por duas ho ras, pela ação de um anel dinamomētrico. A leitura da deforma ção é convertida em pressão e o valor ē denominado indice de expansão (IE). Estabelece categorias de muito crîtica e não crĩ tica para diferentes valores de IE. Esse processo foi designado pela sigla PVC ("potential volume change").

Para amostras indeformadas de solos e de rochas, a ISRM (1971) sugere a medida da expansão uniaxial, com sobrecarga, e sem sobrecarga, com resultados apresentados em porcentagens. 0 primeiro processo foi utilizado por Nascimento, 01 iveira e Graça (1966) e Ducan, Dunne e Petty (1968) para diferentes tipos de rochas. 0 segundo processo foi utilizado por Murayama e Yagi (1966), para argilitos estratificados, e por Frazão, Mioto e Santos (1976) para argilitos, folhelhos argilosos e arenitos ar gilosos. 


\subsection{CRITERIOS BASEADOS EM ENSAIOS DE PRESSAO DE EXPANSAO}

Para os propósitos da Geologia de Engenharia, muitas vezes, mais importante que determinar, direta ou indiretamente, a ex pansão, $\bar{e}$ conhecer qual a pressão que o material pode manifes tar nesse processo. E, dependendo do tipo de obra civil, adota- se o mëtodo de ensaio que melhor reflita as condições às quais esta submetido o material "in situ".

Assim sendo, a prōpria definição do que seja pressão de ex pansão fica dependendo do mëtodo de ensaio, ou vice-versa.

Jenning (1963, in Agarwal e Sharma, 1974) cita diferentes definições de pressão de expansão, quais sejam:

a) pressão que deve ser aplicada para que não aconteça nem expansão, nem contração, quando uma amostra, sob pressão, ē sub metida à inundação;

b) pressão necessäria para manter a amostra em seu volume original quando $\bar{e}$ inundada, sob condições de pressão original;

c) pressão necessāria para manter a amostra no seu volume de campo quando é inundada, isto é, sem modificação de volume sob carga igual aquela de soterramento, e

d) pressão necessāria para comprimir a amostra ao seu volu me original, quando $\bar{e}$ inundada e deixada expandir livremente sob pequena pressão.

A definição a $\bar{e}$ a adotada pela ISRM (1971), Brekke (1965), Agarwal e Sharma (1974), Didier (1972 e 1974), em que a amostra, no ensaio, sofre apenas uma pequena pressão de ajuste ou de aco modação do sistema, mas deixa em aberto a questão das condições originais de pressão sobre a amostra; o que não acontece com as definições constantes nos itens $\underline{b}$ e $c$.

A questão da manutenção do volume constante de amostra sob situação de pressões original, ou de campo, reflete melhor as situações que prevalecem em fundações de obras civis. Os mëto dos de ensaio que se baseiam nessas definições são vulgarmente chamadas de métodos "a volume constante".

Horta da Silva (1975) descreve diversos métodos que se baseiam na definição constante do item $\underline{d}$, em que ē permitida a ex 
pansão das amostras e a pressão de expansão é determinada apōs aplicações de pressões crescentes, em estägios, e a intervalos de tempo regulares. Quanto às condições de pressão sobre a amos tra, contudo, baseiam-se nos conceitos contidos nas definições constantes dos itens $\underline{b}$ e $\underline{c}$. Chen (1974 e 1975) tambëm executou ensaios baseados na definição constante do item d. Estes mëto dos, são variantes do mëtodo de ensaio rotineiro de adensamento.

As condições em que as amostras são ensaiadas dependem, por sua vez, do tipo de obra civil. Se se trata de fundações, o ensaio deve, de preferência, ser efetuado com amostras intactas, ou seja, com suas características intrínsecas mantidas inaltera das e, se for a volume constante, que a pressão inicial reflita as condições reinantes "in situ". Quando se trata de solos que se destinam a aterro, ou à regularização de subleito de estra das, de argilas de preenchimento de fendas, principalmente em zonas fraturadas e cisalhadas em tūneis cortados em maciços rochosos, muitas das características originais são fatalmente alteradas. Assim, os parāmetros com os quais as amostras deverão ser ensaiadas serão obtidos a partir de outros ensaios tecnologicos, ditados pelos critērios de projeto.

5 APARELHAGENS UTILIZADAS PARA DETERMINACÃO DA EXPANSÃO E DA PRESSAO DE EXPANSAO CONSTANTES DA LITERATURA

Como a composição mineralögica, o teor da fração argi losa e os limites de consistência são determinados por aparelhagem e mētodos já consagrados, deter-se-ā na descrição das aparelha gens mais difundidas para a determinação da expansão e da pressão de expansão.

\subsection{EXPANSAO}

A aparelhagem usada para medida da expansão, com exceção da do mëtodo de Foster (in Zandonadi e Santos, 1972), não ē padronizada; serä diferente conforme a amostra seja remoldada ou indeformada, e se esta apresenta ou não estratificações.

Amostras remoldadas necessitam de um anel que as confinem lateralmente, pois precisam ser consolidadas previamente. 0 a nel comumente usado $\bar{e}$ um componente normal de uma cēlula edomé- 
trica convencional. A indeformada pode ser ensaiada com confina mento lateral, em cēlula edomētrica, ou sem confinamento, tal como em Nascimento, 01 iveira e Graça (1966).

As variações de volume são rotineiramente medidas com a utilização de relógios comparadores ou defletōmetros. São posi cionados na direção vertical quando se usa cêlula edométrica (Dunncan, Dunne e Petty, 1968 e Nascimento, 01iveira e Graça, 1966), ou colocados em direções triortogonais como em Murayama e Yagi (1966), em Frazão, Mioto e Santos (1976) e em ISRM(1976) e em ISRM (1971), para medidas simultâneas das expansões parale las e perpendiculares às estratificações.

\subsection{PRESSAO DE EXPANSÃO}

A aparelhagem para a determinação da pressão de expansão tam bëm não é padronizada. São utilizadas cēlulas edométricas con vencionais, como em Brekke (1965), Bjerrum, Brekke, Moun e Selmer-01sen (1963), Agarwal e Sharma (1974), ISRM (1971), Horta da Silva (1975) e outros, ou cēlulas modificadas como em Didier (1972 e 1974) Chu e Mou (1974), Aitchinson e Martin (1974) e Es cārio e Saez (1974).

0 suprimento de àgua ao corpo de prova pode ser por inunda ção como em Brekke (1965), Bjerrum; Brekke, Moun e Se1mer-01sen (1964), ISRM (1971), Horta da Silva (1975), ou com controle de sucção como em Alpan (1959), Aitchinson e Martin (1974), Chu e Mou (1974), Escārio e Saez (1974) e Kassif, Baker e Ovadia(1974). A āgua pode ainda ser utilizada na forma de vapor, como Didier (1972 e 1974).

os dispositivos de carga e de medição variam, tal como no caso das cēlulas edomētricas, conforme os objetivos do estudo. os mais largamente usados consistem do sistema tradicional de prensas de alavancas; em alguns casos são utilizadas prensas de outros modelos. Os sistemas de medição baseiam-se preponderante mente no uso de relógios comparadores acoplados a anëis dinamomētricos.

Os ensaios podem tambēm ter monitoração automätica, como em Agarwal e Sharma (1974), Kazda (1957) e Didier (1972 e 1974).

A medição tambēm pode ser efetuada por transdutores e com registro automätico dos resultados, como em Didier (1972 e 1974). 
6 METODOLOGIA E APARELHAGEM ADOTADAS PARA MENSURACAO DA PRESSAO DE EXPANSAO

0 mētodo da medida da pressão de expansão "a volume cons tante" tem sido cada vez mais utilizado. Isto se deve às consta tações de que a expansão é inversamente proporcional à "contrapressão" a que è submetido o material expansivo, e que existe para um dado material uma determinada "contra-pressão" que o im pede de expandir. Tão importante quanto estas constatações $\bar{e}$ a de que a pressão de expansão decai, rapidamente, se uma pequena expansão é permitida (Didier, 1972 e Bjerrum, Brekke, Moun e Selmer-01sen, 1964). Estes são os principais motivos que susten taram a adoção do mētodo "a volume constante" neste estudo.

0 sistema adotado para mensuração da pressão de expansão fol desenvolvido pelo Agrupamento de Petrologia da Divisão de Minas e Geologia Aplicada do Instituto de Pesquisas Tecnológicas do Estado de São Paulo S.A. Frazão, Farjallat e Palm (1978)apresentaram resultados preliminares sobre o desempenho desse sistema na determinação da pressão de expansão de algumas amostras de argila.

6.1. METODO DE ENSAIO "A VOLUME CONSTANTE"

0 mētodo de determinação da pressão de expansão "a volume constante" consiste em não permịtir qualquer variação volumētrí ca de um corpo de prova durante a absorção de āgua; isto é, qual quer tentativa de expansão ou de contração, do corpo de prova, é impedida pela aplicação ou retirada de pressão sobre o mesmo, respectivamente. De acordo com este método, a pressão necessā ria para manter constante o volume do corpo de prova, durante o ensaio, è a sua pressão de expansão.

\subsection{APARELHAGEM}

A aparelhagem adotada é constituĩda por uma cēlula edomé trica, uma prensa de pequeno porte com dois relógios comparadores, um servo controle com dois transdutores, e um registrador potenciométrico multicanal.

\subsubsection{Célula Edométrica}

A célula edomëtrica é do tipo convencional. Seus componen- 
tes podem ser vistos na Figura 1. Foi construĩda em latão e sua geometria obedeceu às sugestões da Sociedade Internacional de Mecānica de Rochas ISRM (1971).

Seus elementos bäsicos são: um anel (A) com diāmetro de $5 \mathrm{~cm}$, ltura de $2 \mathrm{~cm}$ espessura das paredes de $4 \mathrm{~mm}$ que, com bordas biseladas na sua parte inferior, assenta-se sobre a su perficie de uma placa porosa, de $3,5 \mathrm{~cm}$ de diāmetro (B), que jaz na base da cëlula; possui ainda um cabeçote (C) ao qual está fixada outra placa porosa (D), de $5 \mathrm{~cm}$ de diāmetro, na sua superficie inferior. Dentro do anel e entre as placas porosas e acondicionado o corpo de prova.

$\mathrm{Na}$ base do corpo da cëlula existe um orifĩcio ao qual foi introduzido um tubo de latão (E), por onde é feito o suprimento de liquido ao corpo de prova, que $\overline{\mathrm{e}}$ montado dentro do anel entre as placas porosas superior e inferior.

As bordas biseladas do anel permitem talhar corpos de prova de amostras indeformadas.

0 diāmetro do anel permite acondicionar um corpo de prova com a ärea do topo igual a $19,63 \mathrm{~cm}^{2}$.

A transmissão de forças sobre o corpo de prova se faz atra vēs de uma rötula de aço (F), colocada entre o cabeçote e prato superior da prensa.

\subsubsection{Prensa}

\subsubsection{Descrição dos elementos bäsicos}

Os elementos básicos da prensa, conforme a Figura 2, são: uma lämina dinamomētrica de aço (A), capaz de suportar atē $1000 \mathrm{~kg}$; dois pratos de aço (B) e (C), um apoiado por meio de dois cutelos na lāmina de aço, e outro solidārio a um pistão (D); um motor trifásico (E), reversível, com potēncia de 1/6 de HP, e uma chave comutadora (F) que, atravēs de uma alavanca (G) acio nada manualmente para cima ou para baixo, permite acionar o mo tor para movimentar o pistão e, consequentemente, o prato a ele ligado, para cima ou para baixo, respectivamente.

Entre os pratos da prensa é colocada a célula edométrica (H). Para operação automätica, o circuito da chave comutadora e integrado ao do servo-controle, eliminando-se a alternativa 
de acionar o motor atravēs da alavanca.

6.2.2.2 Descrição dos elementos de medição

os elementos de medição são dois relögios comparadores e dois transdutores (vide detalhe na Figura 3 ).

Um dos relógios está instalado no prato inferior, na sua parte anterior (A), tem capacidade para medir atē $30 \mathrm{~mm}$ e divisões de $0,01 \mathrm{~mm}$, e a ponta de sua haste fica em contato com um parafuso regulāvel suportado na placa superior. Nesta forma, o relógio tem condições de medir a altura do corpo de prova. Neste trabalho ele será denominado de relógio comparador de deformação.

o outro relógio comparador (B) estā instalado sob a lämina de aço, tem capacidade para medir atë $30 \mathrm{~mm}$ e divisões de 0,01 $\mathrm{mm}$, e a ponta de sua haste toca a lâmio no seu centro geomētri co. Sua função è acusar as cargas aplicadas sobre a lâmina, e por isso possui um ponteiro de arraste que fixa, a cada momento, o valor máximo de carga atingido. Neste trabalho ele será denominado de relógio comparador de carga.

Quanto aos transdutores, um estä instalado no prato infe rior (C) nas mesmas condições que o relógio comparador de defor mação, mas situado ào lado oposto; o outro (D) estā instalado sob a lâmina de aço.

os transdutores, tal como o relọgio comparador de deformacão, são ajustāveis por meio de parafusos (E) suportados na pla ca superior, no caso do de deformação, e na inferior, no caso do de carga.

As posições ajustadas podem ser fixadas atravēs de contraporcas $(F)$.

Como os transdutores são elementos dependentes do servo controle, a descrição de suas características e funcionamento en contra-se no item a seguir.

\subsubsection{Servo-Controle}

o servo-controle é constituido por um circuito eletrōnico composto de setores com funções específicas que, basicamente, são: um detetor de nível, uma lógica de comutação, uma lögica 
de espera e de "drivers" de relês e de dois transdutores. 0 dia grama de blocos da Figura 4 ilustra integração dos circuitos.

\subsubsection{Transdutores}

o termo transdutor, aqui utilizado, refere-se a um dispos $\underline{i}$ tivo eletro-mecãnico capaz de transformar variações de deslocamento em variações de tensão elëtrica. E do tipo LVDT ( Linear Variable Differential Transformer), tambēm chamado de transformador diferencial.

Os exemplares utilizados foram construídos pela Divisão de Engenharia Mecānica do IPT.

São constituĩdos por um cilindro de aço de $90 \mathrm{~mm}$ de comprí mento por $19 \mathrm{~mm}$ de diāmetro, contendo em seu interior um nūcleo de "permalloy" de $30 \mathrm{~mm}$ de comprimento por $6 \mathrm{~mm}$ de diāmetro, en volvendo o ponto mēdio de uma haste guia, de $120 \mathrm{~mm}$ de compri mento por $2,5 \mathrm{~mm}$ de diämetro, que se movimenta livremente no in terior de trēs enrolamentos. Estes consistem em um primärio, na posição central, e alimentado por tensões senoidais na faixa de 1,5 a $8 \mathrm{khz}$, e em dois secundärios, posicionados um de cada lado do primärio, que geram tensões tambēm senoidais e proporcionais aos deslocamentos do nūcleo. Detalhes dos circuitos eletrô nicos dos transdutores encontram-se na figura 5.

Cada transdutor ē operado em conjunto com um circuito eletrônico que gera tensão senoidal de excitação no enrolamento primārio e analisa as tensões, de fases opostas, fornecidas pelos secundärios, processa-as e fornece um sinal de saída na for ma de tensão contínua.

Quando o nücleo ocupa posição central, em relação ä posição dos enrolamentos, obtëm-se o zero elëtrico, para o qual a tensão de saîda ē nula.

A tensão de saĩda em um ponto, fora do zero elëtrico, è tal que a amplitude e a polaridade representam o valor e a pos ção do ponto em relação ao zero elētrico. Assim, de um lado do zero elëtrico tem-se saĩdas negativas, e do outro positivas.

os transdutores utilizados apresentam faixa linear de utilização de $-3 V a+3 V$, correspondendo $1 V$ para cada $1 \mathrm{~mm}$ deslocado. 
Dentre os transdutores utilizados, o que se situa entre os pratos da prensa cuida de informar sobre variações de altura do corpo de prova durante o ensaio. Seră, aqui, denominado de trans dutor da deformação. O que estā alojado sob a lâmina de aço informa sobre as cargas a ela transmitidas. Serā denominado de transdutor de carga.

Podem operar em 2 condições alternativas, sendo: (a) o trans dutor de deformação emite sinais para manter constante a altura do corpo de prova e o transdutor de carga emite sinais referentes às cargas necessārias para que isto aconteça, ou (b) o transdutor de carga emite sinais para manter carga constante e 0 de deformação emite sinais referentes às variações de altura.

A alternativa (a) è a que se aplica ao método de ensaio adotado. A (b) e usada quando se deseja compactar o corpo de pro va a uma carga constante.

Esse processo, entretanto, sō se realiza com a participa ção do detetor de nîvel.

\subsubsection{Detetor de nîvel}

Este tem a finalidade de analisar os sinais emitidos pelo transdutor de deformação, e comparä-los com o referencial a ele imposto. Este referencial è um minimo intervalo de deformação que se permite ao corpo de prova para que o sistema possa ser acionado. Dentro desse intervalo estā posicionado o zero elëtri co do transdutor de deformação. O ințervalo é ajustāvel e o ado tado foi de $10 \mu \mathrm{m}$.

Qualquer valor de deformação que ultrapasse o citado inter valo é enviado à lögica de comutação.

\subsubsection{Lōgica de comutação}

A lögica de comutação é o setor do servo-controle onde se tem a opção de operar, manual ou automaticamente, pela mudança de posição de uma chave no painel do instrumento.

Se estā posicionado para "automätico", o sinal vindo do de tetor de nīvel è enviado diretamente para a lögica de espera é de "drivers" de relês.

Se estā na posição "manual", o sinal é bloqueado e sō ē 
transmitido por ação do operador ao tocar um dos botões disponi veis.

\subsubsection{Lögica de espera e de "drivers" de relês}

Este setor recebe informações atravēs da lögica de comutação e, por meio de um circuito de potência, gera a corrente necessāria para acionar os relés do motor.

Para evitar que ocorram bruscas reversões, que podem danificar o motor, existe um sistema de espera que aguarda por al guns segundos a confirmação do sinal, para então acionar os re1ès.

os relès têm a função de, quando acionados, fazer o motor girar num ou outro sentido, a partir de inversão de fases que o alimentam.

Uma fonte de alimentação ligada à rede elētrica (110V-CA) fornece tensões estabilizadas para os circuitos lógicos e para os transdutores.

\subsubsection{Registrador}

A função do registrador e gravar os registros referentes às pressões desenvolvidas durante o ensaio, a partir dos sinais re cebidos dos transdutores.

0 registrador utilizado è do tipo potenciométrico, dispondo de 4 canais, modelo KB-48, fabricado pela Rikadenki Kogyo Co. Ltd.

Os registros são efetuados em papel cuja largura $\overline{\mathrm{e}}$ de 10 polegadas $(25,40 \mathrm{~cm})$ com divisões de 0,2 polegadas $(0,52 \mathrm{~mm})$, que se movimenta com velocidades regulāveis de $\mathrm{cm} / \mathrm{s}$ e $\mathrm{cm} / \mathrm{h}$.

Nos ensaios efetuados operou-se com 2 canais, com um trans. dutor conectado em cada um, obtendo-se os registros referentes às pressões e ãs deformações, separada e simultaneamente.

\subsection{CALIBRAÇAO DO SISTEMA PRENSA/SERVO-CONTROLE/REGISTRADOR}

Para operação do sistema prensa/servo-controle procedeu-se a uma prévia calibração dos transdutores em função dos relógios comparadores, e para obtenção dos registros procedeu-se a uma prēvia calibração do registrador em função do relögio compara dor de carga. 


\subsubsection{Calibracão dos Transdutores}

A calibração dos transdutores visou posicionar a faixa de linearidade de um deles dentro da faixa de operação de cargas e a de outro dentro da faixa de operação de deformações.

a) Transdutor de carga

Para o transdutor de carga adotou-se o seguinte procedimen to:

1) colocou-se um cilindro de aço entre os pratos da prensa;

2) aplicou-se uma carga de $450 \mathrm{kgf}$ sobre o cilindro;

3) conectou-se um voltímetro ao transdutor e, atravēs do parafuso, ajustou-se seu zero elétrico à carga imposta ao cilin dro, fixando-se, a seguir, a posição atingida;

4) reduzlu-se a carga aplicada a zero e, em segulda, rein! ciou-se o carregamento, interrompendo-o a cada intervalo de 50 kgf e lendo-se, no voltímetro, o valor da tensão de saĩda apresentada pelo transdutor.

0 carregamento teve sequência atē a carga de $900 \mathrm{kgf}$.

os dados obtidos são apresentados na Tabela 1 e no gräfico da Figura 6 .

b) Transdutor de deformação

0 ajuste do transdutor de deformação è executado antes de se iniciar cada ensaio, devido às diferentes alturas dos corpos de prova ensaiados. 0 ajuste è efetuado pelo deslocamento do pa rafuso atê que o zero elētrico do transdutor coincida com a altura do corpo de prova.

\subsubsection{Calibração do Registrador}

A calibração do registrador visou fazer com que as deforma ções da placa dinamomētrica manifestadas durante os ensaios, fossem convertidas para registro continuo em papel na forma de valores de pressões.

Para tanto, procurou-se compatibilizar a faixa de linearidade do transdutor com a largura do papel utilizāvel para regis tro. 
Assim, optou-se por fazer com que a largura do papel equivalesse a $50 \mathrm{kgf} / \mathrm{cm}^{2} \mathrm{e}$, consequentemente, cada menor divisão tornou-se igual a $0,5 \mathrm{kgf} / \mathrm{cm}^{2}$, para uma ārea do topo do corpo de prova de $19,63 \mathrm{~cm}^{2}$.

Para se chegar à calibração procedeu-se da seguinte maneira:

1) colocou-se um cilindro de aço entre os pratos da prensa;

2) fez-se o prato superior tocar o topo do cllindro aplicando-se $0,25 \mathrm{kgf} / \mathrm{cm}^{2}$, como carga de ajuste;

3) conectou-se o transdutor ao registrador;

4) posicionou-se a pena de registro no ponto correspondente ao zero da escala desejada no papel;

5) escolheu-se a escala de amplificação no registrador que mais se aproximasse da mäxima tensão gerāvel pelo transdutor em sua faixa 1 inear; que foi de $5 \mathrm{~V}$;

6) aplicaram-se cargas, de modo contínuo, atē que o relögio comparador acusasse $441,6 \mathrm{kgf}$, o que equivale a $22,5 \mathrm{kgf} / \mathrm{cm}^{2}$ para a ārea de $19,63 \mathrm{~cm}^{2}$;

7) como 5V não atendia a escala desejada houve defasagenș entre o valor registrado e o acusado no relógio, que foram corrigidas atravës da utilização do "vernier" do registrador;

8) retornou-se à carga a zero e a nova defasagem ocorrida foi corrigida do mesmo modo descrito anteriormente.

Os procedimentos constantes dos intens 6,7 e 8 , foram repetidos atē que não mais houvesse defasagem entre as leituras no relógio e as registradas.

A seguir, para verificar a correlação entre as pressões lidas no relō gio e as registradas, optou-se por proceder a aplicações de pressões em estāgios de $2,5 \mathrm{em} 2,5 \mathrm{kgf} / \mathrm{cm}^{2}$, desde 0,0 atē $42,5 \mathrm{kgf} / \mathrm{cm}^{2}$, fixan do-se os valores pelo relógio e lendo-se os registros.

Apōs atingir-se a pressão māxima desejada, procedeu-se ao des carregamento, nas mesmas condições acima mencionadas, fixando-se, agora, - registro e lendo-se os valores obtidos no relögio.

os resultados encontram-se na Tabela 2 e Figura 7. 


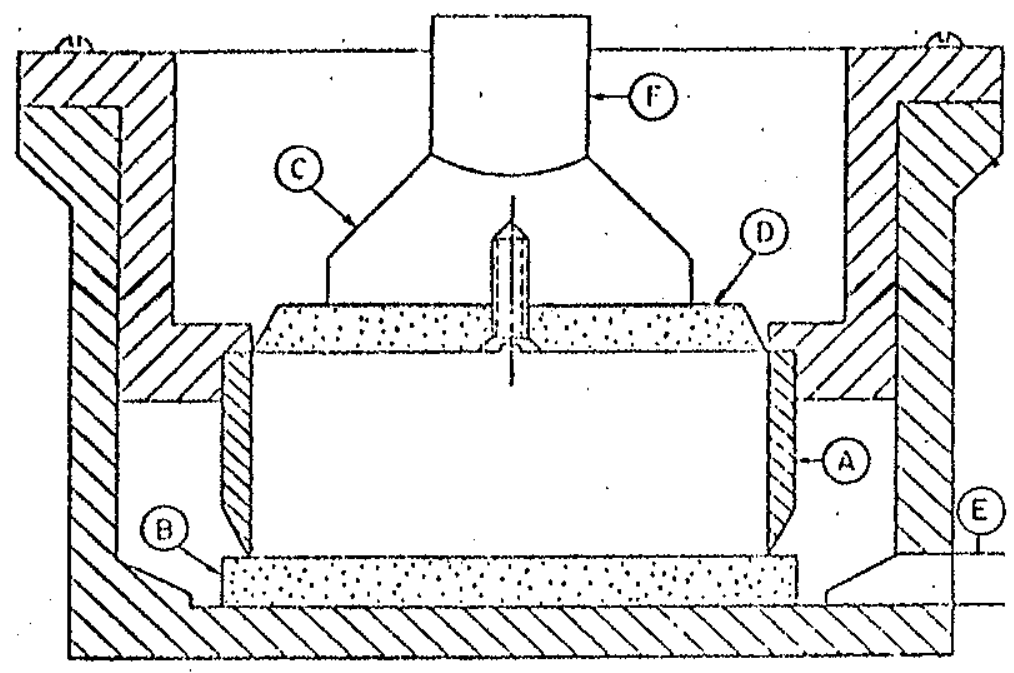

Figura 1 - Corte esquemätico da cēlula edomé trica utilizada na determinação da pressão de expansăo. Principais el ementos: anel (A); placas porosas (B e D); cabeçote (C); tubo (E) e rótula (F). Escala 1:1

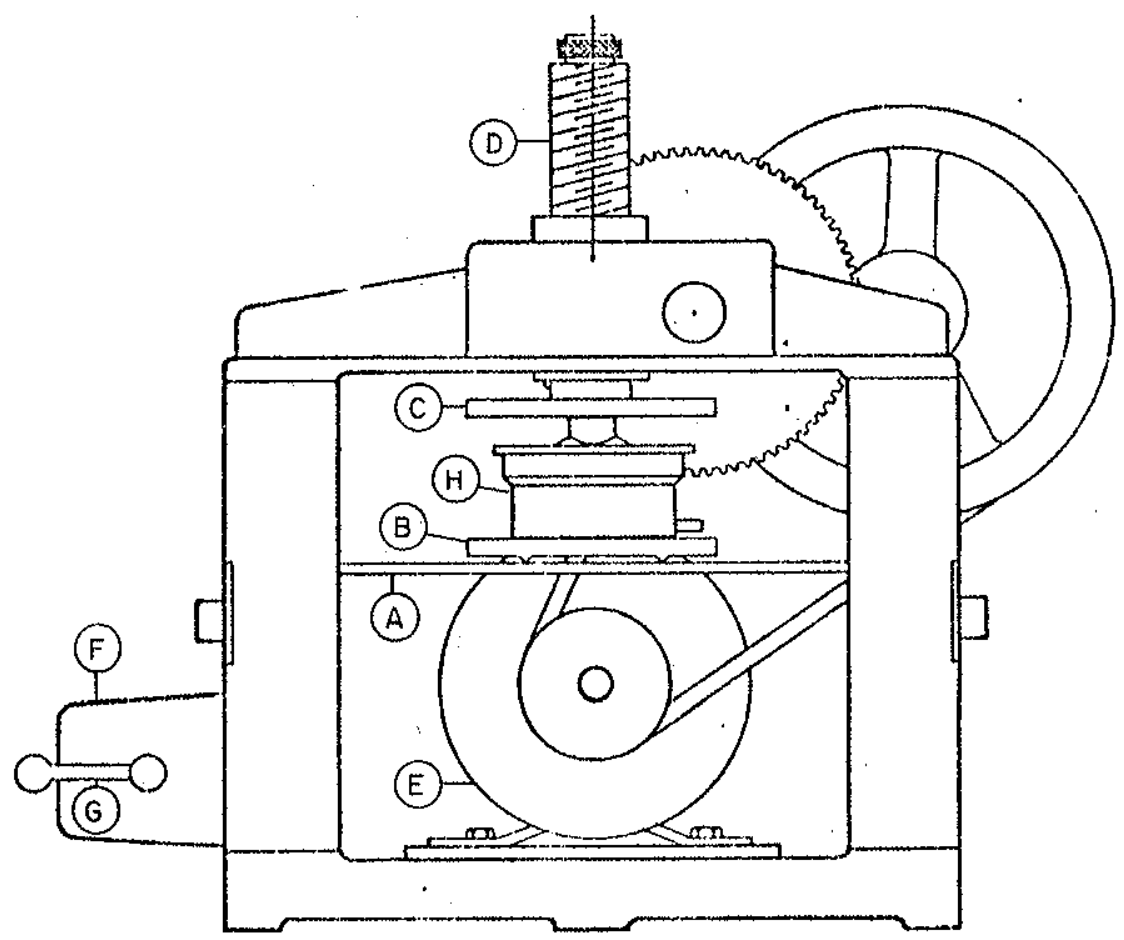

Figura 2 - Vista frontal da prensa utilizada na de terminação da pressão de expansão, com a célula e-dométrica $(H)$. Principais elementos da prensa: 1âmina dinamometrica $(A)$; pratos $(B$ e C); pistão (D); motor (E); chave comutadora $(F)$ e alavanca da chave comutadora (G). Escala 1:5 


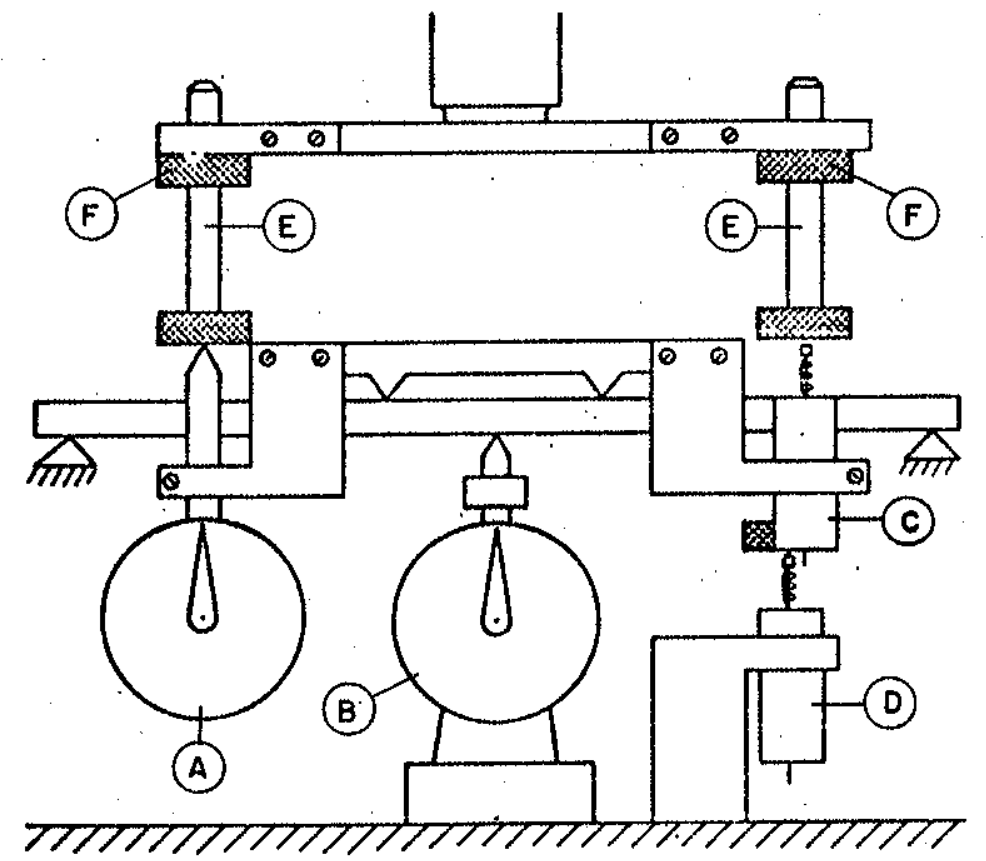

Figura 3 - Detalhe da prensa com a distribuição dos elementos de medição: relögio compara dor de deformação (A); reiōgio comparador de carga (B); transdutor de deformação (C) ; transdutor de carga (D); parafusos (E) e contra-porcas $(F)$. Escala $1: 3$

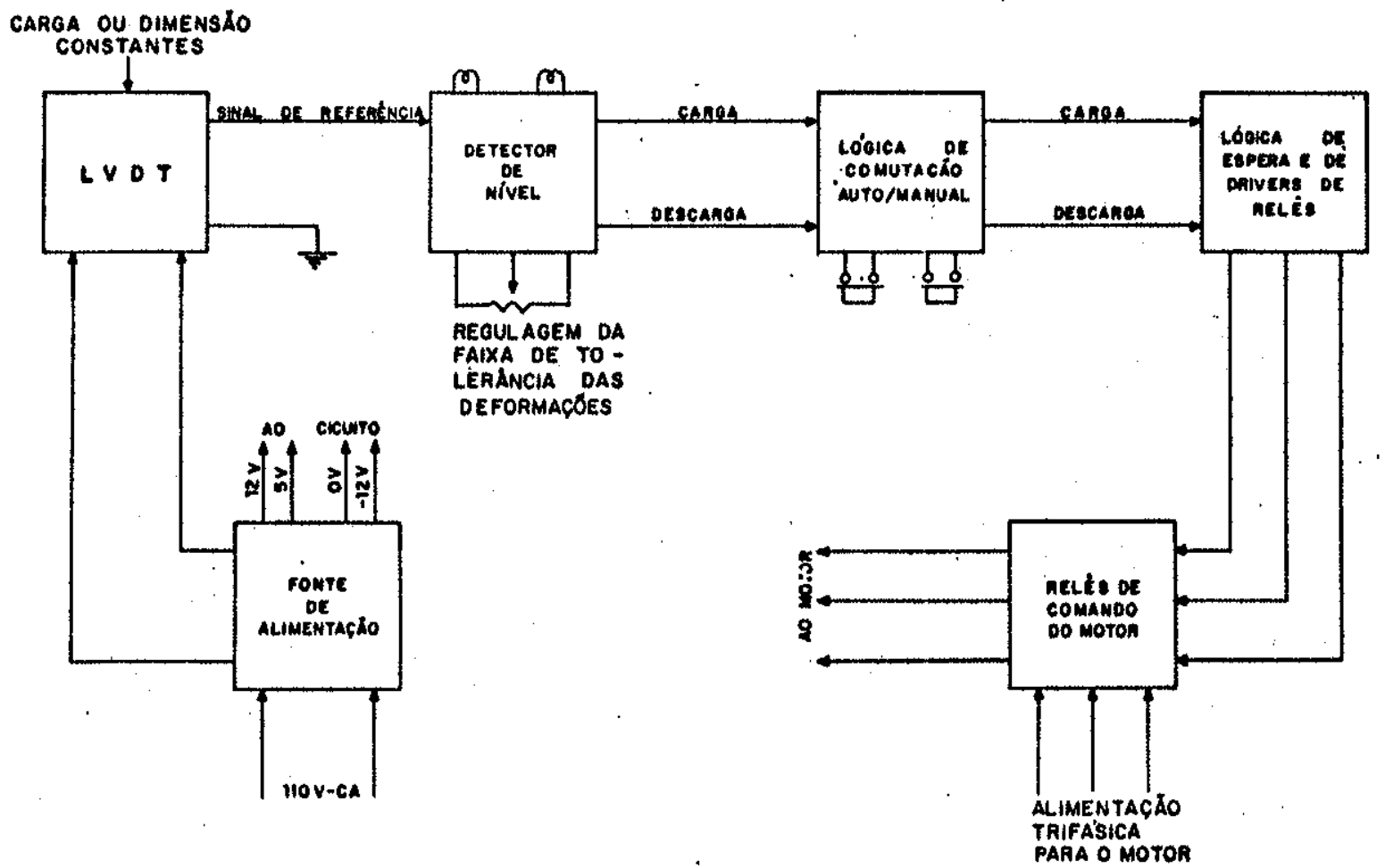

Figura 4 - Diagrama de blocos do servo-controle 


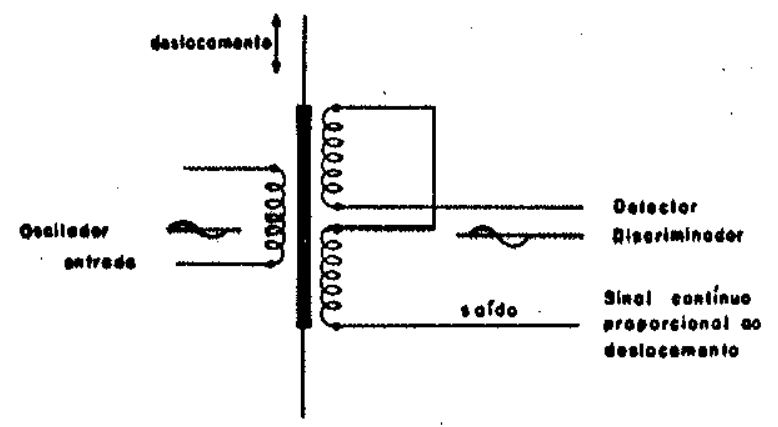

Figura 5 - Detalhes do circuito $\underline{\mathrm{e}}$ létrico dos transdutores.

Tabela I - Resultados da calibração do transdutor de carga em função do relógio comparador de carga.

\begin{tabular}{|c|c|c|}
\hline \multirow{2}{*}{$\begin{array}{l}\text { RELOGIO } \\
\text { (kgf) }\end{array}$} & \multicolumn{2}{|c|}{ TRANSDUTOR } \\
\hline & (V) & $(\Delta V)$ \\
\hline 000 & $-4,00$ & \\
\hline 050 & $-3,54$ & 015 \\
\hline 100 & $-3,09$ & 0,80 \\
\hline 150 & $-2,62$ & 018 \\
\hline 200 & $-2,14$ & 0.40 \\
\hline 250 & $-1,67$ & 046 \\
\hline 300 & $-1,21$. & 0,40 \\
\hline 350 & $-0,73$ & 0,70 \\
\hline 400 & $-0,26$ & ו, \\
\hline 450 & $+0,19$ & 0 \\
\hline 500 & $+0,65$ & \\
\hline 550 & +1.11 & 0,40 \\
\hline 600 & +1.57 & \\
\hline 650 & $+2,05$ & 0.40 \\
\hline 700 & $+2,51$ & 0 \\
\hline 750 & $+2,97$ & \\
\hline 800 & $+3,42$ & 0,40 \\
\hline 850 & $+3,88$ & 015 \\
\hline 900 & $+4,33$ & 0,40 \\
\hline
\end{tabular}




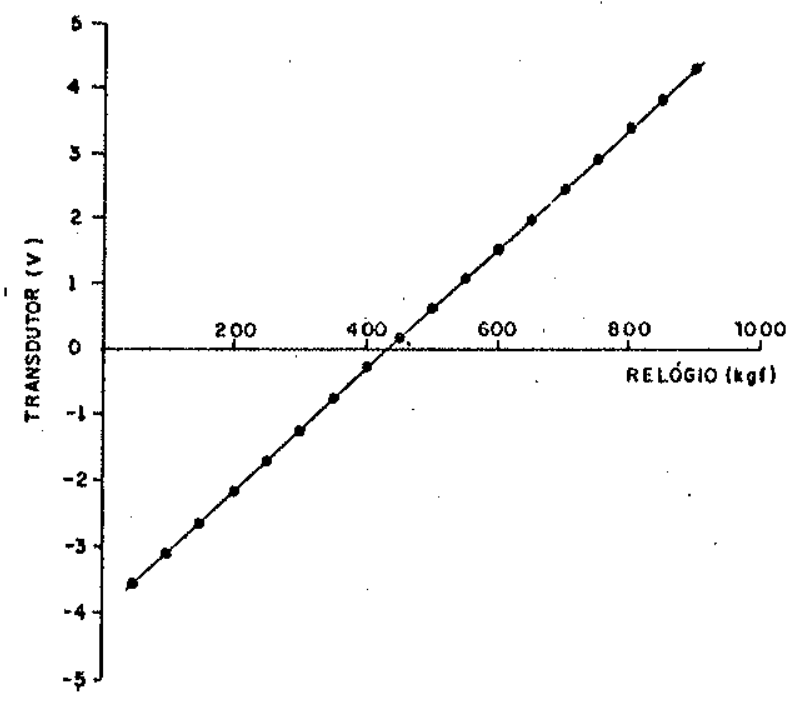

Eigura 6 - Distribuição dos valores apresentados pelo transdutor de carga em função do relógio com parador de carga.

Tabela 2 - Resultados da calibração do registrador em função do relögio comparador de carga.

\begin{tabular}{|c|c|c|c|}
\hline \multirow[t]{2}{*}{$\begin{array}{l}\text { CARGA } \\
\text { (kgf) }\end{array}$} & \multirow[t]{2}{*}{$\begin{array}{l}\text { PRESSAO } \\
\text { CALCULADA } \\
\left(\mathrm{kgf} / \mathrm{cm}^{2}\right)\end{array}$} & \multicolumn{2}{|c|}{$\begin{array}{l}\text { PRESSAO } \\
\text { OBTIDA } \\
\left(\mathrm{kgf} / \mathrm{cm}^{2}\right)\end{array}$} \\
\hline & & (1) & (2) \\
\hline 49,07 & 2,5 & 2,50 & 2,83 \\
\hline 98,15 & 5,0 & 5,00 & 5,22 \\
\hline $1.47,22$ & 7,5 & 7,50 & 7,69 \\
\hline 196,30 & 10,0 & 10,00 & 10,19 \\
\hline 245,37 & 12.5 & 12,60 & 12,59 \\
\hline 294,37 & 15,0 & 15,10 & 15,13 \\
\hline 343.53 & 17,5 & 17,70 & 17,58 \\
\hline 392,60 & 20,0 & 20,10 & $20,12^{\circ}$ \\
\hline 441,60 & 22,5 & 22,70 & 22,61 \\
\hline 490,75 & 25,0 & 25,10 & $25,10^{\circ}$ \\
\hline 539,53 & 27.5 & 27,60 & 27,64 \\
\hline 588,90 & 30,0 & 30,00 & 80,12 \\
\hline 637,97 & 32,5 & 32,60 & 32,65 \\
\hline 687,05 & 35,0 & 35,00 & 35,13 \\
\hline 736,12 & 37,5 & 37,60 & 37,60 \\
\hline 785,20 & 40,0 & 40,20 & 40,07 \\
\hline 834,27 & 42,5 & 42,80 & 42,80 \\
\hline
\end{tabular}

Nota: (1) No carregamento

(2) No descarregamento 


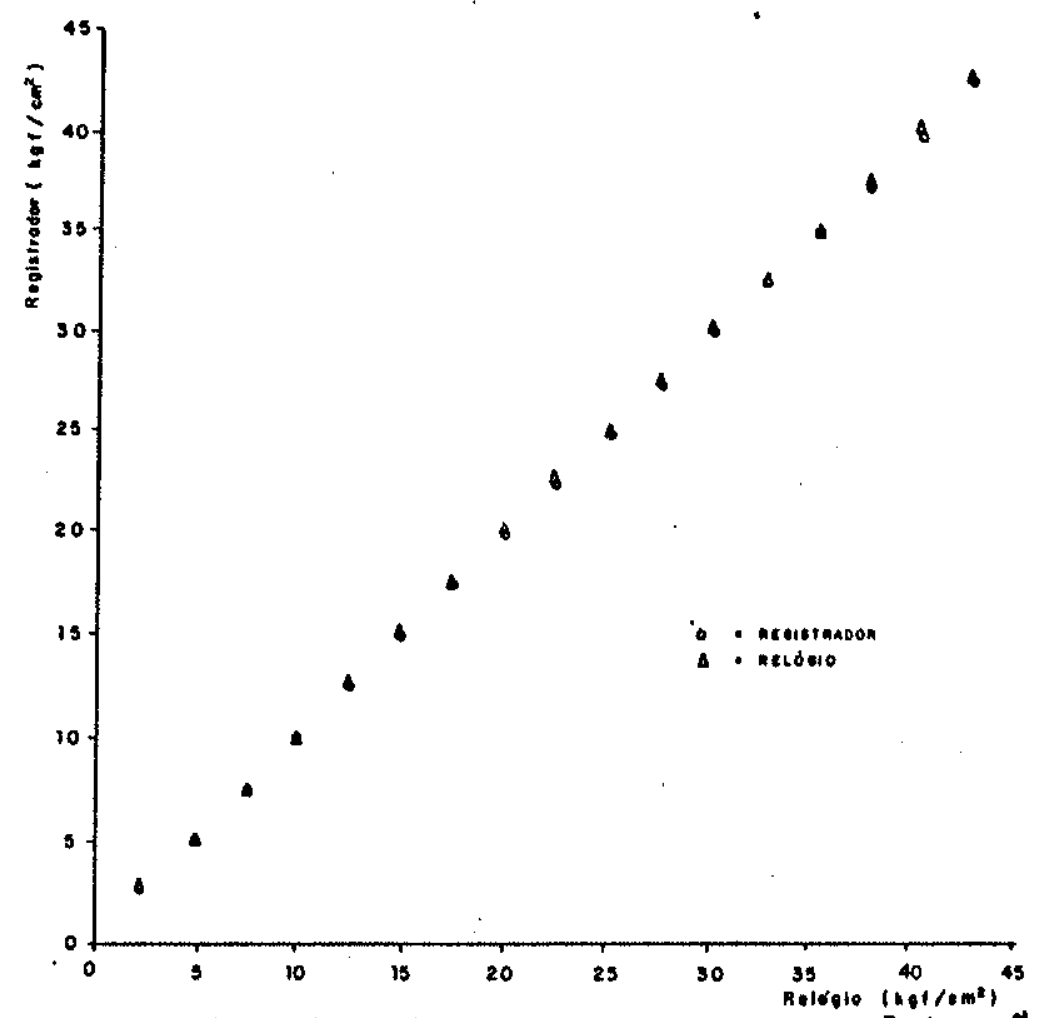

Figura 7 - Distribuiçāo dos dados da calibração do registrador em função do relógio comparador' de carga. 


\section{MATERIAL}

Tendo em conta que são diversos os fatores que influenciam a ex pansão e a pressão de expansão, optou-se, nesse estudo, por man ter constante alguns deles e investigar a influência de outros. Desse modo escolheu-se uma argila que fosse monomineralálica e com predominância de particulas na faixa menor que $2 \mu \mathrm{m}$, para manter sob controle a influência da natureza mineralógica e da granulometria. Outro requisito $\bar{e}$ que a argila tivesse capacidade de expansão acentuada de modo a permitir que, mesmo variando os parámetros dos corpos de prova, a pressão de expansão fosse mensurāvel dentro da faixa de precisão dos instrumentos usados.

Desta forma, optou-se por utilizar uma argila denominada Volclay-SPV, produzida pela American Colloid Co., Illinois,USA, e que foi adquirida da Cosmoquïmica S.A., que a fornece no mercado brasileiro para diversos usos industriais. Essa argila atende aos requisitos anteriormente mencionados, é freqdentemente citada na literatura por diversos pesquisadores que a tēm utilizado, inclusive como material de referēncia em estudos comparativos de propriedades tecnológicas de outras argilas(Zandonadi e Santos 1972, 1978, e Zandonadi 1972; Grim, 1962 e 1968).

\section{PREPARACAO DO MATERIAL}

A amostra Volclay foi inicialmente submetida a um peneiramento na malha no 270, cuja abertura è de $0,53 \mathrm{~mm}$ (ASTM E-11), de modo a eliminar aglomerados de argila constatados e obter-se, assim maior homogeneidade granulométrica.

Do material passante na malha $n 9270$ foram colhidas as porções necessärias para as diversas anālises e ensaios executados.

\section{CARACTERIZAÇAO DO MATERIAL}

A caracterização da amostra Volclay-SPV foi executada atra vēs de anālises quỉmicas, mineralögica e granulomētrica, deter minação do peso especĩfico real, dos limites de consistência e da expansão livre. 


\subsection{ANALISES QUIMICAS}

As anālises quỉmicas visaram conhecer a composição quĩmica, a capacidade de troca de cātions (CTC) e os cātions trocāveis (CT) da amostra de argila Volclay-SPV.

A composição química foi determinada por fluorescencia de raios-x, e por espectrofotometria de absorção atômica, sendo os resultados apresentados na forma de öxidos (vide Tabela 3 ).

A CTC foi determinada por saturação da argila com acetato de amōnio e medindo-se a quantidade de $\mathrm{NH}_{4}{ }^{+}$absorvido por titulação com hidrōxido de sōdio, sendo os resultados apresentados em $m E q / 100 \mathrm{~g}$ de material seco (vide Tabela 4).

os cátions trocāveis foram determinados por espectrofotometria de absorção atômica sobre o líquido extraỉdo da argila,após sua saturação com acetato de amōnio no processo de determinação da CTC, sendo os resultados apresentados em $\mathrm{mEq} / 100 \mathrm{~g}$ ( $v$ ide Tabela 4).

Estas anālises foram executadas pelo Centro de Anālises Qu micas e Instrumentais da Divisão de Quĩmica e Engenharia Quimica do IPT.

\subsection{ANALISE MINERALOGICA}

A anālise mineralögica foi executada por difratometria de raios-X sobre material coletado da suspensão utilizada na anālise granulométrica, concentrado por centrifugação e aplicado orientadamente sobre lāmina de vidro. Foi analisado no estado natural, com adição de etileno-glicol e apös aquecimento a 300 o C (durante $2 \mathrm{~h}$ ). Utilizou-se um difratōmetro Rigaku Denki, operando com voltagem de $35 \mathrm{kV}$, amperagem de $15 \mathrm{~mA}, 2 \theta=19 \mathrm{~min}$, fator de escala de $1 / 500$ e velocidade do papel de $10 \mathrm{~mm} / \mathrm{min}$. Usou-se radiação $K_{\alpha}$ do $\mathrm{Cu}(\lambda=1,540 \AA)$.

0 s resultados encontram-se na figura 8.

\subsection{ANALISE GRANULOMETRICA}

Nesta anālise procedeu-se de acordo com as recomendações feitas por Suguio (1973) para sedimentos inconsolidados.

Adotou-se o processo da pipetagem, dispersando-se, aproxima damente, $25 \mathrm{~g}$ do material em $1000 \mathrm{ml}$ de ägua deionizada, à qual 
se adicionou $1 \mathrm{~g}$ de pirofosfato de södio, coletando-se $20 \mathrm{ml}$ da suspensão a uma profundidade de $20 \mathrm{~cm}$, a intervalos de tempo de decantação que obedeceram à lej de Stokes, calculada para tempe ratura de $20 \% \mathrm{C}$, e utilizando-se a escala granulomētrica de Wentworth. Nesta escala, são consideradas como fração argila as particulas menores do que 4 am.

A distribuição granulomētrica das particulas encontra - se na Tabela 5 .

\subsection{DETERMINAÇAO DO PESO ESPECIFICO REAL}

0 peso específico real foi determinado segundo o mëtodo do picnōmetro, de acordo com a norma ABNT MB-28/76. Devido à alta hidrofilia manifestada pela argila, houve surgimento de intensa aglomeração que impediu a necessāria individualização das partī culas exigidas nessa anāise. Para superar esse incoveniente, substituiu-se a ägua destilada por "xilol", que mostrou desem penho satisfatörio (vide Tabela 5 ).

A determinação do peso específico real foi executada pela Seção de Cerāmica do Agrupamento de Tecnologia Inorgānica da Divisão de Química e Engenharia Química do IPT.

\subsection{LIMITES DE CONSISTENCIA}

Os limites de consistência determinados foram o de liqui dez e o de plasticidade, obedecendo as recomendações das normas ABNT MB-30 e MB-31, respectivamente.

0 s resultados encontram-se na Tabela 5 .

os limites de consistência foram determinados pela Seção de Mecānica de Solos do Agrupamento de Geotecnia da Divisão de Engenharia Civil do IPT.

\subsection{EXPANSAOO LIVRE}

Para obter-se uma previsão da capacidade de expansão, foi executado o ensaio de expansão livre, de acordo com sugestão de Foster (in Zandonadi e Santos, 1972).

os resultados encontram-se na Tabela 5 .

\section{DISCUSSAO DOS RESULTADOS DA CARACTERIZACAO DA AMOSTRA}

$\mathrm{Na}$ Tabela 3 nota-se que a amostra de argila Volclay-SPV u- 
sada neste estudo apresenta uma composição quimica muito semelhan te à usada por Zandonadi (1972), sendo ligeiramente mais silicosa e ligeiramente menos aluminosa. Os outros ōxidos estão em quanti dades muito semelhantes.

$\mathrm{Na}$ Tabela 4 nota-se um valor de CTC inferior ao determinado por Zandonadi (op.cit.), mas os cātions trocāveis mais frequentes, em ambas as amostras, são os mesmo, ou seja, $\mathrm{Na}, \mathrm{Ca}$, e $\mathrm{Mg}$, nesta ordem. A diferença constatada è que a amostra usada neste trabalho ē mais sōdica e menos magnésica do que a usadapor zandonady (op.cit.). o cálcio apresenta-se em teores multo semelhantes.

Na Figura 8 nota-se, que o argilo-mineral predominante $\vec{e}$ uma esmectita, atravēs do comportamento manifestado nos estados natural, com etileno-glicol e com aquecimento, onde as reflexões 001 apresentaram valores de $14,60,17,31$ e $9,60 \AA$, respectivamen te. Ilita ocorre subsidiariamente.

$\mathrm{Na}$ Tabela 5 observa-se predomināncia de partículas menores que $0,004 \mathrm{~mm}(90,79 \%)$.

$\mathrm{Na}$ Tabela 5 nota-se que os valores dos limites de consis tēncia são muito pröximos aos determinados por samuels (1950, in Grim, 1962) para uma montmorilonita sōdica. Digno de nota $\bar{e}$ seu alto indice de plasticidade $(525 \%)$.

0 peso especifico real $\left(2,67 \mathrm{~g} / \mathrm{cm}^{3}\right)$, è de valor igual ao determinado por Zandonadi (1972) e estä na faixa de valores espe rados para uma montmorilonita, segundo Grim (1958) (Tabela 5).

0 valor de expansão livre, mostrou-se major do que o apre sentado por Santos e Zandonadi (1972). O valor de 26,5 m 1 pode ser considerado como extremamente elevado, se comparado com os valores apresentados por Zandonadi (1978) (Tabela 5). 
Tabela 3 - Composição quĩmica da amostra' de argila Volclay-SPV

\begin{tabular}{|l|c|c|}
\hline \multirow{2}{*}{ Compostos } & \multicolumn{2}{|c|}{$\begin{array}{c}\text { Teores } \\
(\%)\end{array}$} \\
\cline { 2 - 3 } & $(1)$ & $(2)$ \\
\hline $\mathrm{SiO}_{2}$ & 63,30 & 60,00 \\
$\mathrm{Al}_{2} \mathrm{O}_{3}$ & 20,60 & 23,30 \\
$\mathrm{Fe}_{2} \mathrm{O}_{3}$ & 3,49 & 3,62 \\
$\mathrm{TiO}_{2}$ & 0,17 & 0,11 \\
$\mathrm{CaO}^{*}$ & 1,16 & 1,43 \\
$\mathrm{MgO}$ & 2,52 & 2,67 \\
$\mathrm{Na}{ }_{2} \mathrm{O}$ & 2,03 & 2,01 \\
$\mathrm{~K}{ }_{2}{ }^{\circ}$ & 0,39 & 0,19 \\
$\mathrm{Perda}$ ao fogo & 6,20 & 6,85 \\
\hline
\end{tabular}

Nota: (1) - Este trabalho

(2) - Zandonadi (7972)

Tabela 4 - Capacidade de troca de cätions e cätions trocāveis da amostra de argila Volclay SPV.

\begin{tabular}{|c|c|c|}
\hline $\begin{array}{c}\text { Capacidade de troca de cätions } \\
(\mathrm{mEq} / \mathrm{lo0g})\end{array}$ & 70,3 & 124,6 \\
\hline Cátions trocäveis $(\mathrm{mEq} / \mathrm{lo0g})$ & $(1)$ & \multicolumn{1}{c|}{$(2)$} \\
\hline $\mathrm{Al}^{3+}$ & 0,78 & 2,78 \\
$\mathrm{Fe}^{3+}$ & 0,16 & 0,49 \\
$\mathrm{Ca}^{2+}$ & 35,43 & 37,80 \\
$\mathrm{Mg}^{2+}$ & 13,98 & 23,46 \\
$\mathrm{Na}^{+}$ & 62,64 & 57,10 \\
$\mathrm{~K}^{+}$ & 1,79 & 2,00 \\
\hline
\end{tabular}

Nota: (1) - Este trabalho

(2) - Zandonadi (1972) 


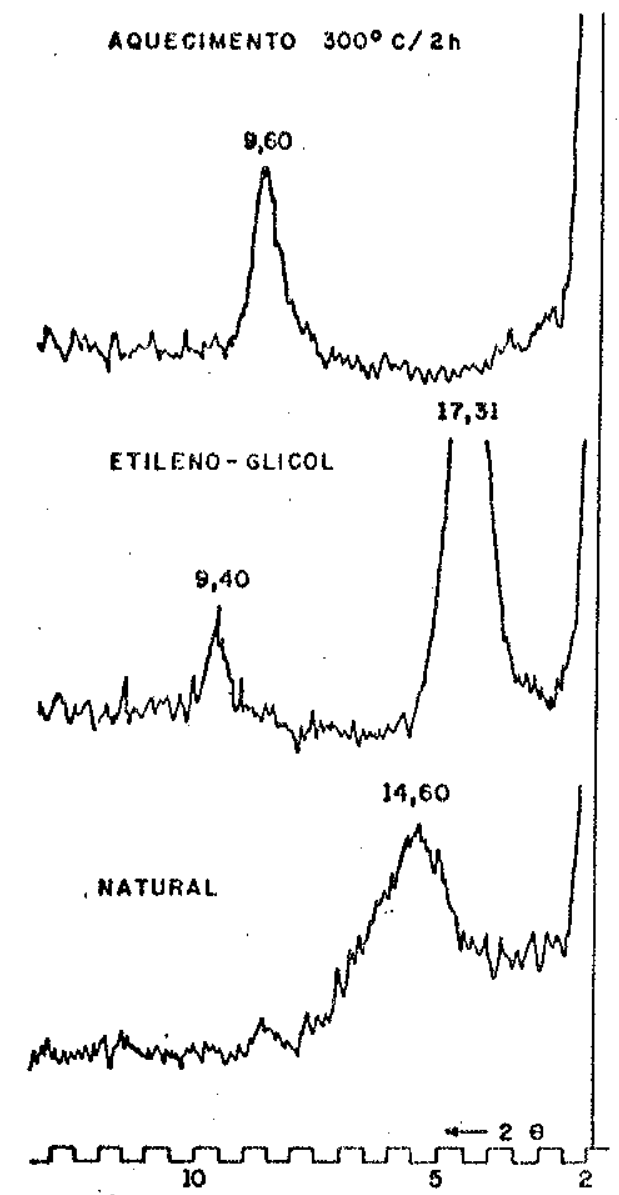

Figura 8 - Resultados da anälise mineralögica, por di fratometria de raios $-X$, da amostra da argila Volclay .. SPV.

Tabela 5 - Algumas propriedades físicas da amostra de argila Volclay-SPV.

\begin{tabular}{|c|c|c|}
\hline Limite de liquidez (\%) & 570 & 623 \\
\hline Linite de plasticidade $(\%)$ & 45 & 41 \\
\hline Indice de plasticidade (\%) & 525 & 582 \\
\hline Peso especifico real $\left(\mathrm{g} / \mathrm{cm}^{3}\right)$ & 2,67 (1) & $2,67 \quad(3)$ \\
\hline Expansão livre (m1) & 26,5 & 18,5 \\
\hline \multirow{2}{*}{ Distribuição granulomëtrica $(\%)$} & Sitte & 9,21 \\
\hline & Argila & 90,79 \\
\hline
\end{tabular}

Nota: (1) - Este trabalho

(2) - Samuels (1950, in Grim, 1962)

(3) - Zandonadi (1972)

(4) - Zandonadi e Santos (1972) 
11 DETERMINACAOO DOS PARĀMETROS DE ENSAIO DE PRESSAO DE EXPANSÄO

os parāmetros de ensajo relativos ao material, considera dos neste trabalho foram umidade inicial e final, densidade ini cial e massa dos corpos de prova.

11.1 PREPARAÇAO DOS CORPOS DE PROVA

Tomou-se a amostra e, dela, pesou-se a quantidade a ser en saiada e tambēm uma alîquota de $5 \mathrm{~g}$ para determinação do teor de umidade inicial de acordo com o descrito no item 11.2, a seguir.

Montou-se a cëlula e o material a ser ensaiado foi lançado, porção por porção, com uma espātula, dentro do anel contendo um papel filtro sobre a placa porosa inferior.

A cada porção lançada, batia-se com a palma da mão na base da cêlula atê que ali se acomodasse todo o material. Introduztu -se, a seguir, o cabeçote da cēlula contendo solidāria a ele a placa porosa e o papel filtro.

\subsection{TEOR DE UMIDADE}

\subsubsection{Procedimento Operacional}

Para determinação do teor de umidade (U) procedeu-se da se guinte maneira (Caputo, 1974): colocou-se o material sobre um vidro de relógio que foi levado à balança, obtendo-se um valor $\left(P_{1}\right)$ que $\bar{e}$ a soma dos pesos do vidro relögio (P), da ägua ( $P_{a}$ ) e das partîculas sölidas $\left(P_{S}\right)$. Em seguida o material foi levado à estufa, com temperatura de $110 \pm 50 \mathrm{C}$, e deixou-se-o secar atē constäncia de peso, quando se obteve um valor $\left(P_{2}\right)$ que é a soma do peso do vidro de relogio (P) e do peso das particulas soli das $\left(P_{S}\right)$.

11.2 .2 Cà1cu1o

$$
\begin{aligned}
& P_{1}=P+P_{a}+P_{s} \\
& P_{2}=P+P_{s} \quad \text { onde: } \\
& U(\%)=\frac{P_{1}-P_{2}}{P_{2}-P}=\frac{P_{a}}{P_{s}} \times 100
\end{aligned}
$$


Apōs o tērmino de cada ensaio determinou-se tambëm o teor de umidade final $\left(U_{f}\right)$ da mesma maneira descrita acima.

\subsection{DETERMINAÇAO DA DENSIDADE DO CORPO DE PROVA}

\subsubsection{Procedimento Operacional}

A cēlula edométrica montada, e sem material, foi levada à prensa movimentou-se o prato supertor até que as piacas porosas superior e inferior se encostassem. Utilizou-se uma pressão de ajus te igual a $0,25 \mathrm{kgf} / \mathrm{cm}^{2}$, a qual, por sua vez, è a mesma utilizáa da no inicio do ensaio. Em seguida colocou-se o relögio compara dor de deformação em zero. Para isto utilizou-se do parafuso su portado na placa superior. Apōs esse ajuste apertou-se a contra -porca, para fixar-se a posição atingida, e movimentou-se o pra to superior da prensa para cima, para liberar a célula.

Apōs a colocação do material dentro da cēlula, como descri to no item 11.1 , levou-se à prensa e procedeu-se ao carregamento ate que o ponteiro do relōgio comparador atingisse a marca correspondente à altura requerida para que o corpo de prova alcançasse a densidade desejada. Ajustou-se o transdutor de defor mação, atravës da movimentaçăo do parafuso apropriado, para man ter constante a altura atingida, e deixou-se o corpo de prova sob pressão atë a estabilização das deformações.

Nos casos em que se desejou manter pressão constante, operou-se impondo-se esse requisito ao transdutor de carga atravēs do ajuste no detector de nivel do servo-controle.

Findando o tempo de permanēncia do corpo de prova sob a pressão imposta, procedeu-se ao descarregamento atē a pressão de $0,25 \mathrm{kgf} / \mathrm{cm}^{2}$, quando, apōs a estabilização das deformações, leu-se a altura obtida.

\section{3 .2 Cālculo}

Calculou-se a densidade atravês da seguinte relação:

$$
\begin{aligned}
& D=\frac{M}{H \times S} \quad \text { onde: } \\
& D=\text { densidade inicial }\left(\mathrm{g} / \mathrm{cm}^{3}\right) \\
& M=\text { massa do corpo de prova }(\mathrm{g})
\end{aligned}
$$




$$
\begin{aligned}
& H=\text { altura do corpo de prova }(\mathrm{cm}) \\
& \mathrm{S}=\text { ärea do topo de corpo de prova }\left(\mathrm{cm}^{2}\right)
\end{aligned}
$$

A densidade, como acima calculada, è tida, a princīpio, co mo densidade ümida $\left(D_{u}\right)$, ou seja, densidade a um certo valor de umidade. De posse do valor de umidade, calculou-se a densida de seca $\left(D_{s}\right)$ pela seguinte relação:

$$
\begin{aligned}
& D_{s}=\frac{D_{u}}{1+U_{i}} \quad \text { onde: } \\
& D_{s}=\text { densidade seca }\left(\mathrm{g} / \mathrm{cm}^{3}\right) \\
& D_{u}=\text { densidade umida }\left(\mathrm{g} / \mathrm{cm}^{3}\right) \\
& U_{i}=\text { teor de umidade inicial }
\end{aligned}
$$

Na relação acima o valor de $U_{i} \vec{e}$ utilizado na forma de pro porção, ou seja, de 0 a 1 .

\subsection{MASSA}

Para a determinação da massa do corpo de prova, tomou-se um vidro de relógio, previamente limpo e seco em estufa a $1109 \mathrm{C}$ ate atingir a constância de peso, o qual foi levado à balança ande foi tarado. Sobre o vidro de relōgio foi lança o o mate rial. Foram pesados com sensibilidade de $0,01 \mathrm{~g}$.

\section{ENSAIO DE PRESSAO DE EXPANSAO}

o procedimento adotado nesse ensaio e o cálculo da pressão de expansão são descritos a seguir.

\subsection{PROCEDIMENTO OPERACIONAL}

Com a cēlula edomētrica entre os pratos da prensa, a estabilização da deformação do corpo de prova jā alcançada e anotada a altura do mesmo sob pressão de $0,25 \mathrm{kgf} / \mathrm{cm}^{2}$, ajustou-se o transdutor de deformação para manter o intervalo de deformação de $\pm 5 \mu \mathrm{m}$ (constante para todos os ensaios). 0 servo-controle, nesse momento, encontrava-se na condição de operação manual. Introduziu-se a mangueira no tubo da base da cēlula edomëtrica, fez-se o nïvel do lîquido, do baläo de suprimento, coincidir com o nivel do topo do corpo de prova, ligou-se o servo-controle para operar automaticamente e, imediatamente, abriu-se a tor 
neira para fornecimento da ägua ao corpo de prova. Apōs $24 \mathrm{~h}$ o ensaio foi interrompido. Procedeu-se à passagem do servo-contro le para a posição manual, ao fechamento da torneira do balão, à retirada da mangueira do tubo da cēlula edomëtrica e ao escoa mento da āgua acumulada dentro da cēlula; leu-se o valor māximo de carga atingida e, a partir daí, impos-se ao servo-controle o descarregamento automātico. Apōs a liberação da cēlula edomētri ca, procedeu-se, imediatamente, a sua desmontagem para libera ção do corpo de prova, de modo a evitar que a ägua remanescente na cēlula pudesse continuar penetrando no corpo de prova, fal seando, assim, seu teor de umidade final. o corpo de prova, e o anel a ele solidārio, tiveram suas superfícies enxugadas e fo ram submetidas ao procedimento para deteminação do teor de umidade final como descrito no item 11.2 .

12.2 CÁLCULO

0 cälculo da pressão de expansão foj executado de acordo com recomendações da ISRM (1971), atravēs da relação:

$$
\begin{aligned}
P E & =\frac{C_{m \bar{a} x}}{S} \quad \text { onde: } \\
P E & =\text { pressão de expansão }\left(\mathrm{kgf} / \mathrm{cm}^{2}\right) \\
C_{m \bar{a} x} & =\text { maior carga registrada }(\mathrm{kgf}) \\
S & =\text { ärea do topo dó corpo de prova }\left(\mathrm{cm}^{2}\right)
\end{aligned}
$$

\section{EXPERIMENTOS}

A parte experimental deste estudo foi subdividida em duas etapas.

Na primeira etapa executaram-se ensaios, com a amostra de argila Volclay-SPV, em corpos de prova:

a) de massas diferentes, quase secas e compactadas estaticamente sob uma pressão constante;

b) de massa constante, quase secos e de densidades secas diferentes, e

c) de mesma massa, de mesma densidade seca e de teores de umidades iniciais diferentes. 
Apesar da expansão e da pressão de expansão de um corpo de prova ser dependente do tempo, dentre outros fatores, adotou-se, 24 h como tempo mäximo de duração dos ensaios. Esta decisão baseou-se em citações de Brekke (1965), o qual verificou que as maiores mobilizações de pressão ocorrem entre as primeiras 2 ou $3 \mathrm{~h}$, e de Chen (1975), o qual afirmou serem $24 \mathrm{~h}$ suficientes pa ra que ocorra $95 \%$ do total da expansão de um corpo de prova.

$\mathrm{Na}$ segunda etapa executaram-se ensaios por um processo con vencional, utilizando-se da amostra de argila Volclay-SPV e de amostras de arenitos argilosos, visando a comparação dos resultados obtidos nas duas etapas. Para se atingir esse propōito, contou-se com a colaboração dos Laboratörios de Mecānica dos So los do Departamento de Engenharia Civil da Escola Politécnica da USP e da Divisão de Engenharia Civil do IPT.

13.1 VERIFICAÇAOO DA INFLUENCIA DA MASSA NA PRESSAOO DE EXPANSAOO 13.1.1 Procedimentos Operacionais

Foram separadas 42 aliquotas de amostra de argila VolclaySPV, com diferentes volumes avaliados visualmente. Apös seca gem em estufa, a $600 \mathrm{C}$ durante $48 \mathrm{~h}$, suas massas e seus teores de umidade foram determinados de acordo com o descrito nos itens 11.4 e 11.2 , respectivamente.

os corpos de prova, preparados de acordo com o descrito no item 11.1, foram levados à prensa., onde foram submetidos a uma compactação estätica sob pressão de $20 \mathrm{kgf} / \mathrm{cm}^{2}$, mantida constante, pelo ajuste do transdutor de carga (item 11.3.1), durante $24 \mathrm{~h}$,

0 procedimento de se aplicar uma determinada pressão de consolidação constante, seguıu recomendações de Brekke (1965) que assim o fez nos ensaios executados sobre corpos de prova de argilas remoldadas colhidas em tūneis na Noruega, onde preenchiam fraturas de um maciço rochoso.

Apōs $24 \mathrm{~h}$ reduziu-se a pressão para $0,25 \mathrm{kgf} / \mathrm{cm}^{2}$ e, apōs a estabilização das deformações, o ensaio foi executado de a.cordo com o procedimento descrito no item 12. 


\subsubsection{Resultados}

Os resultados encontram-se na Tabela 6 e Figura 9, onde se nota que os valores de densidade seca variaram de 1,14 a $1,25 \mathrm{~g} / \mathrm{cm}^{3}$. 0 valor mëdio foi $1,19 \mathrm{~g} / \mathrm{cm}^{3}$, o desvio padrão $0,02 \mathrm{~g} / \mathrm{cm}^{3}$ e 0 coeficiente de variação $1,68 \%$.

Para evitar que houvesse interferéncia da densidade seca na anälise da influência da massa na pressão de expansão, selecionou-se o intervalo em torno da média $\left(1,18\right.$ a $\left.1,20 \mathrm{~g} / \mathrm{cm}^{3}\right)$, on de se situaram $64,29 \%$ dos valores de densidade obtidos. Admitiu - se que as variações de densidade no citado intervalo não afeta ram os resultados de pressão de expansão.

os resultados obtidos no intervalo selecionado encontram - se na Tabela 7 , onde se nota que os valores de massa e de umidade inicial adotados variaram de 3,00 a $40,80 \mathrm{~g}$ e de 0,63 a $0,90 \%$, respectivamente. Não foram utilizadas massas maiores, porque traziam dificuldades na manutenção da padronização dos procedimentos de preparação dos corpos de prova como descrito no item 11.1. Os valores de expansão oscilaram entre 3,11 e $6,19 \mathrm{kgf} / \mathrm{cm}^{2}$ e as umidades finais entre 35,80 e $105,34 \%$. 0 valor médio da $P E$ foi de $4,68 \mathrm{kgf} / \mathrm{cm}^{2}$, desvio padrão de $0,78 \mathrm{kgf} / \mathrm{cm}^{2}$ e coeficiente de variação de $16,67 \%$.

\subsubsection{Correlação e Discussão dos Resultados}

A dispersão dos resultados das densidades não era esperada e deve ter tido como causa uma heterogeneidade na microestrutura do corpo de prova. Não se pôde, contudo, comprovar essa hipoo tese.

Procurando-se correlacionar os valores de pressão de expan são com os de massa, lançaram-se os dados em um gräfico da forma $P E=f(M)$, como $i$ lustra a Figura 10.

Utilizou-se da função $y=a x /(1+b x)$ adotada por Caprariis, Lindelmann e Collins (1976) para determinar a volume ótimo de amostras em estudos litológicos e paleontológicos. Ajustou-se a curva e verificou-se que os valores de pressão de expansão au mentam à medida que aumentam os valores de massa. A influéncia da massa na pressão de expansão é maior no intervalo de 3 a a proximadamente $15 \mathrm{~g}$; a partir daĩ a influência começa a decres- 
cer, pois os valores de pressão de expansão tendem à estabiliza ção.

Não constaram, via de regra, da literatura consultada, investigações sobre influência da massa na pressão de expansão. Duas exceções foram constatadas. Chen (1974 e 1975), a partir de diversas determinações sobre corpos de prova de argilito, com densidade seca e teores de umidade iniciais constantes, mas com diferentes espessuras, afirmou que a variação destas, não in fluencia a pressão de expansão. Em outras palavras: a massa não influi na pressão de expansão. Ruiz (1963), por outro lado, a partir de ensaios com uma argila de preenchimento de fenda de basalto, afirma que a melhor reprodutibilidade dos ensaios de pressão de expansão acontecia quando a massa era igual a 1, 5 ve zes a ārea do topo do corpo de prova, ou, o que equlivale dizer que a pressão de expansão é influenciada pela massa quando essa proporção não é obedecida. Na presente investigação seria uma massa de cerca de $30 \mathrm{~g}$, uma vez que a ārea do topo dos corpos de prova foi de $19,63 \mathrm{~cm}^{2}$. Deve-se ressaltar que estes autores não utilizaram o método a volume constante nas suas investiga ções, o que impede a comparação com os resultados obtidos neste estudo.

A seguir, para verificar qual a correlação entre umidade final e pressão de expansão, lançaram-se os dados em gráficos do tipo $P E=f\left(U_{f}\right)$, como ilustra a Figura 11. Admitia-se que a relativa dispersão dos valores de pressão de expansão, em função dos de massa, era devido a diferentes teores de água absorvida. Is to não põde ser constatado devido, novamente, a uma relativa dispersão dos resultados. Chen (1975) afirmou não haver relação entre $P E$ e $U_{F}$.

Finalmente lançou-se $U_{f}=f(M)$ (vide Figura 12). Calcularam-se as regressões obtendo-se melhor ajuste para a regressão potencial, cuja equação é do tipo $y=a \cdot x^{b}$, onde: $a=0,400$ e $b=191,232$. 0 valor do coeficiente de correlação foi de $-0,791$.

Verifica-se na figura 12 que corpos de prova de massas menores, que, por sua vez, estão diretamente relacionadas a alturas menores, atingem maiores teores de umidade ao final dos en saios. Tendo em conta que se fixou um gradiente hidrāulico cons 
tante, quando do suprimento de àgua ao corpo de prova, e que se fixou uma duração constante para o ensaio (24 h), os corpos de prova de massas menores devem ter sido favorecidos por uma me nor distância para percolação da āgua, resultando num umedeci mento mais eficiente. A distribuição dos dados, que permitiu o ajuste de uma função do tipo potencial, indica, teoricamente, que por mais que se aumentasse a massa, ou a altura do corpo de prova, mantidos inalterados gradiente hidrāulico e a duração do ensaio, sempre haverā uma dada taxa de absorção d'āgua e que, ao diminuir progressivamente a massa, a umidade final tende ao infinito.

\subsubsection{Conclusões Parciais}

As constatações aqui efetuadas permitem as seguintes con clusões parciais:

1) apesar de mantidas constantes as condições de compactação (consolidação), para diferentes valores de massa, os corpos de prova devem ter assumido microestruturas diferentes, e isto pode ter influído nos valores de densidade seca obtidos;

2) à medida que aumentaram os valores de massa, aumentaram os de pressão de expansão; a influência da massa foi maior para valores menores que $15 \mathrm{~g}$;

3) a afirmação de Ruiz (1963) de que a massa deveria ser igual ou maior que 1,5 vezes a àrea do topo do corpo de prova, para que houvesse a reprodutibilidade desejāvel nos valores de pressão de expansão, não foi confirmada nesta etapa do estudo;

4) o fato de Chen (1974 e 1975) afirmar que a massa não in flui na pressão de expansão tambēm não foi confirmado;

5 ) para corpos de prova de uma mesma densidade e massa diferentes deve haver um dado gradiente hidrāulico ou uma dada du ração dos ensaios que compatibilize esses parāmetros.

13.2 VERIFICAÇÃO DA INFLUENCIA DA DENSIDADE SECA NA PRESSÃO DE EXPANSAOO

\subsubsection{Procedimentos Operacionais}

Nessa investigação adotou-se manter constante a massa e os 
teores de umidade inicial pröximos de zero e variar as densidades secias.

A determinação dos valores de massa e de umidade inicial para cada corpo de prova obedeceu os procedimentos descritos an teriormente.

Escolheu-se a massa de $30 \mathrm{~g}$ por situar-se no intervalo em que decresce a influência da massa na pressão de expansão.

Para se obterem as diferentes densidades submeteu-se um corpo de prova à pressão de $0,25 \mathrm{kgf} / \mathrm{cm}^{2}$ e outro a $45 \mathrm{kgf} / \mathrm{cm}^{2}$. os outros valores de densidade foram obtidos com pressões escoIhidas entre esses limites.

\subsubsection{Resultados}

Os resultados obtidos encontram-se na Tabela 8 , onde se ve rifica que os teores de umidade inicial variaram de 0,3 a $0,8 \%$ e as densidades secas obtidas se situaram entre 0,98 e $1,34 \mathrm{~g} / \mathrm{cm}^{3}$. As pressões de expansão variaram de 1,63 a $7,71 \mathrm{kgf} / \mathrm{cm}^{2}$, e as umidades finais de 36,80 a $79,80 \%$.

\subsubsection{Correlação e Discussão dos Resultados}

Nota-se, na Tabela 8 , que não houve uma desejāvel gradua ção para as densidades secas; crē-se que os motivos sejam os mesmos que foram considerados quando da compactação dos corpos de prova na investigação da influência da massa na pressão de expansão.

A fim de verificar a correlação entre pressão de expansão e densidade seca lançaram-se os resultados em gräfico da forma $P E=f\left(D_{s}\right)$ (Figura 13). Calcularam-se as regressões e a que melhor se ajustou foi a potencial, cuja equação $\bar{e}$ do tipo $y=a \cdot x^{b}$, com: $a=5,246$ e $b=1,969$. 0 valor do coeficiente de correla ção foi de 0,973. A linear e a exponencial, contudo, apresentaram valores, desse coeficiente, extremamente pröximos ao da potencial: 0,970 e 0,966 , respectivamente.

Nota-se que existe uma boa correlação entre a densidade se ca e pressão de expansão. Apesar da função que melhor se ajusta ser a potencial, pode-se considerar a correlação como linear da faixa estudada. Chen (1974 e 1975) chegou a resultados semelhan tes, mas concluiu ser a correlação, entre $D_{S}$ e PE, da forma ex - 
ponencia). Didier (1972), Brackley (1974), Satyanarayana (1974) e Viajayvergia e Ghazzaly (1974) encontraram, tambëm, maiores valores de pressão de expansão em corpos de prova com densida des maiores.

Procurou-se, novamente, correlacionar a pressão de expan são com umidade final lançando-se $P E=f\left(U_{f}\right)$ (vide Figura 14). os resultados mostraram, novamente, uma dispersão relativamente grande, indicando não ter havido boa correlação entre estes paràmetros.

A seguir lançaram-se as umidades finais contra as densidades secas em gräfico da forma $U_{f}=f\left(D_{s}\right)$ (vide Figura 15). A correlação mostrou-se fraca, apesar de, inicialmente, crêr-se que os valores de umidade final fossem inversamente proporcio nais aos de densidade seca, por admitir-se, "a priori", que cor pos de prova mais densos fossem menos permeāveis à ägua.

13.2 .4 Conclusões Parciais

os resultados obtidos nesta etapa permitem as seguintes con clusões parciais:

1) a densidade seca è um parāmetro de grande influência na pressão de expansão; sua correlação ē potencial, mas pode ser considerada como linear na faixa estudada;

2) a umidade final não apresentou correlação com a pressão de expansão;

3) a densidade seca näo foi correlacionāvel com a umidade final.

13.3 VERIFICAÇAO DA INFLUENCIA DO TEOR DE UMIDADE INICIAL NA PRESSAO DE EXPANSAOO

\subsubsection{Procedimentos Operacionais}

Nesta investigação mantiveram-se constantes a massa seca e a densidade seca dos corpos de prova, e variaram-se os teores de umidade iniciais.

Adotou-se um valor de massa igual a $30 \mathrm{~g}$ e valores de densidade seca entre 1,18 e $1,20 \mathrm{~g} / \mathrm{cm}^{3}$.

Para obtenção dos diferentes teores de umidade colocou-se 
a amostra em um recipiente aberto e deixou-se-a exposta à umida de atmosférica de uma sala com umidade relativa de cerca de $100 \%$ e temperatura ambiente de $22 \% \mathrm{C}$.

A cada 24 h colhia-se uma nova porção da amostra e determinava - se o seu teor de umidade.

De posse do valor do teor de umidade $\left(U_{j}\right)$ calculou-se o va lor da massa ümida $\left(M_{u}\right)$ que o corpo de prova deveria ter para satisfazer ao valor da massa seca $\left(M_{S}\right)$ estipulado, atravēs da förmula $M_{u}=M_{s}\left(1+U_{i}\right)$.

A seguir calculou-se qual a altura (H) que os corpos de prova deveriam apresentar para se obter a densidade seca especí ficada, atravēs da expressão constante do item 11.3.

os corpos de prova foram preparados de acordo com o procedimento descrito anteriormente e deixados sob pressão na prensa até que se estabilizassem na altura calculada.

\subsubsection{Resultados}

Os resultados encontram-se na Tabela 9 , onde se nota que os teores de umidade iniciais variaram de 6,20 a $28,48 \%$, as pressões de expansão oscilaram entre 2,70 e $6,21 \mathrm{kgf}^{-\mathrm{cm}^{2}}$ e os teores de umidade finais se situaram entre 35,78 e $52,65 \%$.

\subsubsection{Correlação e Discussão dos Resultados}

Para verificar a influência da umidade inicial na pressão de expansão lançaram-se os valores em gräficos do tipo $P E=f\left(U_{j}\right)$ (vide Figura 16). Calcularam-se as regressões e a que melhor se ajustou foi a linear, cuja equação é do tipo y $=a x+b, \quad$ com $a=0,121$ e $b=6,498$. 0 coeficiente de correlação foi de $-0,788$.

0 grāfico mostra que para umidades baixas os valores da pressão de expansão tornam-se mais elevados que para umidades mais altas.

A tendēncia da curva obtida ē intersectar a abcissa em 6,5 $\mathrm{kgf} / \mathrm{cm}^{2}$, valor pouco superior ao māximo obtido nesta investigação $\left(6,21 \mathrm{kgf} / \mathrm{cm}^{2}\right)$ e a ordenada em $57 \%$, que ë pröximo ao mäximo valor de umidade final $(52,65 \%)$. Se a regressão de fato for 11 near, deduz-se que existirā um teor de umidade inicial para o qual não haverā expansão e, portanto, não se manifestaria a 
pressăo de expansão; no caso, poderia ser em torno de $55 \%$. A julgar pelo valor de limite de plasticidade, que foi de $45 \%$, crê-se que a amostra, nas condições de ensaio a volume constante, não apresentaria pressão de expansão apreciāvel, pois com umidade inicial de $57 \%$ encontrar-se-ia adentrando a faixa de plasticidade (525\%), na qual tenderia a se acomodar às "contrapressões" aplicadas para impedir eventuais expansões. Esta hipō tese, contudo, não pôde ser comprovada por razões präticas, ou seja, havia dificuldades para se obterem teores de umidade elevados para a amostra. A grande hidrofilia da amostra não permitia uma homogeneização perfeita da umidade, obtendo-se diversos aglomerados quando a āgua, mesmo vaporizada, tocava a amostra. Haja vista que para a obtenção do teor de umidade de $28,48 \%$ a amostra teve que permanecer durante 10 dias em cāmara ümida, adsorvendo āgua da atmosfera ambiente lentamente.

Chen (1975) obteve resultados que contrariam os alcançados nesta investigação, ou seja, nos seus experimentos a pressão de expansão não foi afetada pela variação da umidade inicial, mantendo-se, os valores, quase iguais para diferentes teores de umidade. Satyanarayana (1974) e Viajayvergia e Ghazzaly (1974), entretanto, obtiveram menores valores de pressão de expansão em corpos de prova com umidades iniciais maiores.

\subsubsection{Conclusöes Parciais}

As constatações aqui efetuadas permitem as seguintes con clusões parciais:

1) umidade inicial influiu na pressão de expansão de modo linear, ou seja, à medida que cresceu a $U_{j}$, decresceu a PE;

2) deve existir um valor de umidade inicial para o qual não hã expansão e, consequentemente, não se manifesta a pressão de expansão;

3) os resultados aqui alcançados não são compativeis com os obtidos por Chen (1975), mas o são com os obtidos por satyanarayana (1974) e Viajayvergia e Ghazzaly (1974). 
13.4 ESTUDO COMPARATIVO DO DESEMPENHO DO SISTEMA ADOTADO FRENTE A UM SISTEMA CONVENCIONAL

Para efeito de comparação do desempenho do equipamento ado tado neste estudo, executaram-se ensaios de pressão de expansão atravēs de um processo no qual é permitida a expansão dos cor pos de prova, sob valores crescentes de pressões. A pressão de expansão $\vec{e}$ definida como aquela que, se fosse aplicada sobre o corpo de prova, impediria a expansão. 0 valor da pressão de expansão ē inferido em um gräfico onde, na ordenada são lançados os valores de expansão e, na abcissa, os valores dos logaritmos das pressões aplicadas.

Este $\vec{e}$ um dos mētodos mais empregados nos laboratörios de Mecānica de Solos do mundo inteiro. Ruiz (1963) utilizou esse mētodo nas suas investigações. Outro mētodo muito empregado è aquele em que se permite a expansão do corpo de prova e a pressão de expansão è definida como sendo a necessāria para recom primir o corpo de prova ao seu volume inicial. Este foi o método empregado por Chen (1974).

$\mathrm{Na}$ presente investigação utilizou-se 2 modalidades do primeiro tipo de ensaio citado. Numa, os corpos de prova foram sub metidos diretamente a pressões com valores prë-fixados, a par tir dos resultados já obtidos pelo processo adotado pelo autor. Noutra, as pressões obedeceram a escala normalmente adotada nos ensaios de adensamento. Denominaremos essas modalidades de no 1 e no 2, respectivamente.

Foram utilizadas cēlulas edomëtricas convencionais e prensas do tipo de alavancas, que são normalmente utilizadas em ensaios de adensamento.

13.4.1 Modalidade no 1

a) Procedimentos operacionais

Este ensaio foi executado à densidade seca de $1,20 \mathrm{~g} / \mathrm{cm}^{3} \mathrm{e}$ teor de umidade inicial de 4,00\%, sobre trēs corpos de prova da amostra de argila Volclay-SPV.

As pressões (p) foram prē-fixadas em $2,00,4,00$ e $8,00 \mathrm{kgf} /$ $\mathrm{cm}^{2}$ e aplicadas, cada uma, a um corpo de prova. Operou-se com a variação do indice de vazios (e) como parāmetro de expansão. 
Determinaram-se o indice de vazios inicial ( $e_{i}$ ) e os indices de vazios apresentados pelos corpos de prova antes e apos a estabilização sob a saturação (ĩndices de vazios finais).

$0 s$ valores dos indices de vazios finais foram lançados em gräficos do tipo $e=f(\log p)$. A ordenada foi fixada no ponto correspondente ao indice de vazios inicial.

A pressão de expansäo foi determinada a partir da intersec çăo da reta, que passa pelos valores de indices de vazios fi. nais, com a ordenada.

Este mëtodo ē conhecido tambëm pela denominação de "mētodo dos três pontos".

b) Resuttados

0 gräfico correspondente a este ensaio encontra-se na figura 17, onde se nota que todos os corpos de prova apresentaram redução nos valores de indices de vazios em relação ao valor ini cial $\left(e_{j}\right)$, quando submetidos a pressões de $2,00,4,00$ e $8,00 \mathrm{kgf} /$ $\mathrm{cm}^{2}$, antes do fornecimento de ägua. Apōs o fornecimento de ägua, apenas o corpo de prova que foi submetido à pressão de $2,00 \mathrm{kgf} /$ $\mathrm{cm}^{2}$ expandiu com valores de indice de vazios final superior ao inicial. 0 que foi submetido a $4,00 \mathrm{kgf} / \mathrm{cm}^{2}$ expandiu, mas apre sentou valor de indice de vazios inferior ao inicial. o que foi submetido a $8,00 \mathrm{kgf} / \mathrm{cm}^{2}$ contraiu, pois apresentou indice de vazios final inferior àquele alcançado antes do fornecimento de ägua.

13.4.2 Modalidade ne 2

a) Procedimentos operacionais

Este ensaio foi executado por Fleury (1978) sobre quatro amostras indeformadas de arenitos silto-argilosos do Grupo Tuba rão, colhidos em fundações de uma obra civit em Sumaré, Estado de São PauTo.

Utilizou-se de um mînimo de três corpos de prova por amos tra. Os teores de umidade iniciais oscilaram entre 25 e $30 \%$ e as densidades secas se situaram em torno de $1,80 \mathrm{~g} / \mathrm{cm}^{3}$ (Fleury, informação verbal).

os corpos de prova foram moldados de modo que seu volume ex 
terno coincidisse com o volume interno do anel da c $\vec{e} l u l a$ edomētrica.

Como não se conhecia, previamente, a faixa de pressões de expansão que as amostras poderiam apresentar, adotaram-se as aplicações de pressões por estāgios, com valores obedecendo a uma progressão geomëtrica de razão dois, a partir de $0,125 \mathrm{kgf} /$ $\mathrm{cm}^{2}$. Esta escala não foi obedecida rigorosamente para todas as amostras, pois dependeu dos valores apresentados pelos primei ros corpos de prova ensaiados.

os corpos de prova permaneceram sob cada uma das pressões durante $24 \mathrm{~h}$. Ao final desse tempo foi fornecida āgua destilada ao corpo de prova que foi deixado expandir atē a estabilização das deformações. A estabilização demorou, na maioria dos casos, sete dias, para cada corpo de prova.

A expansão foi calculada atravēs da relação $\Delta H / H \times 100$, on de: $\Delta H=$ acrēscimo mäximo de altura e $H=$ altura inicial do cor po de prova. Os valores de expansão foram lançados em grä́fico do tipo $\Delta H / H \times 100=f(\log p)$.

A pressão de expansão foi determinada pela intersecção dos segmentos de reta, que unem os valores de expansão, com a orde-nada.

b) Resultados

Os resultados encontram-se no gräfico da Figura 18, onde se nota que:

1) na amostra 1 houve expansão nos corpos de prova submet dos às pressões de atē $0,500 \mathrm{kgf} / \mathrm{cm}^{2}$; o que foi submetido a $1,000 \mathrm{kgf} / \mathrm{cm}^{2}$ contraiu-se; a pressão de expansão foi interpolada em $0,59 \mathrm{kgf} / \mathrm{cm}^{2}$;

2) na amostra 2 houve expansão nos corpos de prova submeti dos a atẽ $0,500 \mathrm{kgf} / \mathrm{cm}^{2}$; a pressão de expansão foi extrapolada em $2,60 \mathrm{kgf} / \mathrm{cm}^{2}$;

3) na amostra 3 houve expansão nos corpos de prova submeti dos a atê $1,000 \mathrm{kgf} / \mathrm{cm}^{2}$; o que foi submetido a $2,000 \mathrm{kgf} / \mathrm{cm}^{2}$ con traiu-se; a pressão de expansão foi interpolada em $1,85 \mathrm{kgf} / \mathrm{cm}^{2}$;

4) na amostra 4 houve expansão nos corpos de prova submet 
dos a até $1,000 \mathrm{kgf} / \mathrm{cm}^{2}$; o que foi submetido a $8,000 \mathrm{kgf} / \mathrm{cm}^{2}$ con traiu-se; a pressão de expansão foi interpolada em $3,10 \mathrm{~kg} / \mathrm{cm}^{2}$.

13.4.3 Ensaios "a Volume Constante" com as Amostras de Arenitos Silto-argilosos

a) Procedimentos Operacionais

0 ensaio "a volume constante" foi executado sobre um corpo de prova, indeformado, de cada uma das amostras de arenitos. Os quatro corpos de prova foram moldados de modo que seus volumes externos coincidissem exatamente com o volume interno do anel da cêlula edométrica. Os teores de umidade inicial e final foram determinados de acordo com os procedimentos descritos anteriormente. Para a determinação da densidade seca, os corpos de prova foram pesados antes do ensaio e, de posse do valor de umi dade inicial, calculou-se a massa seca atravēs da expressão do item 13.3.1. o volume considerado no cálculo da densidade foi o do anel da célula edométrica, cujo valor ē de $39,26 \mathrm{~cm}^{3}$.

0 ensaio foi executado de acordo com os procedimentos já descritos.

b) Resultados

os resultados obtidos constam da Tabela 10 , onde se nota que as umidades iniciais apresentaram-se muito abaixo e as densidades secas próximas aos dos corpos de prova utilizados no ensaio de acordo com a modalidade no 2 . Os valores de pressão de expan são, por sua vez, foram superiores.

\subsubsection{Discussão dos Resultados}

Nota-se nas figuras 17 e 18 e na Tabela 10 que os valores de pressão de expansão obtidos, tanto pela modalidade no 1 , como pela no 2, são inferiores aos obtidos pelo processo a volume constante, tanto para a amostra Volclay-SPV como para as de are nitos.

Is to se deve, provavelmente, ao fato, jä constatado por di versos pesquisadores, de que a pressão de expansão dimimui mesmo que uma pequena expansão seja permitida. Esta observação é vālida, principalmente para o ensaio sobre a amostra Volclay, 
pois o minimo valor apresentado no ensaio a volume constante, com corpos de prova de parämetros semelhantes, foi de $4,33 \mathrm{kgf} /$ $\mathrm{cm}^{2}$ (vide Tabela 6, corpos de prova 10, 80, 90 e HM, e Tabela 9 , corpo de prova $V H-1)$. Nos ensaios sobre os arenitos, além do fato da expansão ser permitida, a umidade inicial deve ter afetado os resultados: no ensaio a volume constante, os teores de umidade iniciais se encontravam cerca de cinco vezes mais bai xos que os teores dos corpos de prova ensaiados segundo a modalidade no 2 (25 a $30 \%)$.

Em ambas as modalidades, nota-se que os valores são inferi dos graficamente, a partir de resultados de expansão, os quais, por sua vez, estão muito dispersos, principalmente os do arenito. Isto leva a que os resultados da pressão de expansão obti dos por esse mëtodo sejam pouco exatos.

Quanto à dificuldade dos ensaios, a modalidade no 2 foi mais trabalhosa e demorada, levando de 7 a 10 dias para determi nação da expansão de um ünico corpo de prova, o que resultou em atë 1 mês para se conhecer a pressão de expansão de uma amostra. A modalidade no 1 levou de 3 a 10 dias para fornecer resultados de expansão dos corpos de prova. o processo a volume constante, por outro 1ado, forneceu o resultado de pressão de expansão em apenas $24 \mathrm{~h}$, com a vantagem adicional de dispensar controle manual dos ensaios, e permitir melhor caracterização da amostra a partir da obtenção de diversos valores de pressão de expansão em curto espaço de tempo. Deve-se ressaltar, contudo, que a quantidade de ensaios executados pelo processo convencional ado tado foi insuficiente para se chegar a uma conclusão definitiva sobre as vantagens do mëtodo a volume constante com monitoração automätica dos ensaios. 
Tabela 6 - Freqüēncias em nümero e em porcentagem das densidades secas.

\begin{tabular}{|c|c|c|}
\hline$D_{S}\left(\mathrm{~g} / \mathrm{cm}^{3}\right)$ & $F(n O)$ & $F(\%)$ \\
\hline 1,14 & 2 & 4,76 \\
1,15 & 2 & 4,76 \\
1,16 & 2 & 4,76 \\
1,17 & 3 & 7,14 \\
1,18 & 8 & 19,05 \\
1,19 & 12 & 28,57 \\
1,20 & 7 & 16,67 \\
1,21 & 4 & 9,52 \\
1,22 & 0 & 0,00 \\
1,23 & 1 & 4,76 \\
1,24 & 0 & 0,00 \\
1,25 & 1 & 4,76 \\
\hline TOTAL & 42 & 99,99 \\
\hline
\end{tabular}

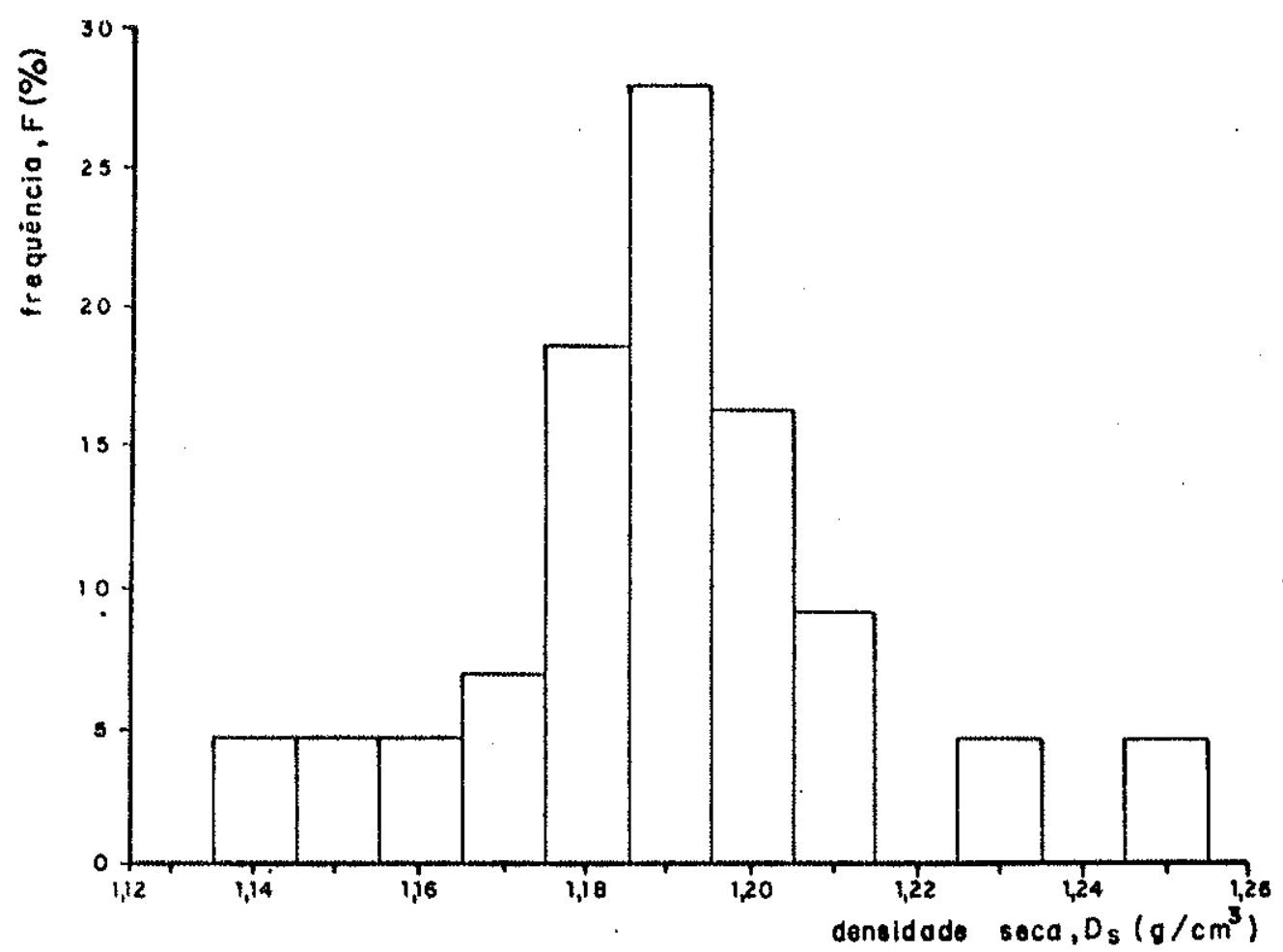

Figura 9 - Distribuição dos valores das freqüēncias em porcentagem das densidades secas. 
labela 7 - Resultados da verificação da influência da massa na pressão de expansao.

\begin{tabular}{|c|c|c|c|c|c|}
\hline $\begin{array}{c}C P \\
(n \varphi)\end{array}$ & $\begin{array}{l}M \\
(g) \\
\end{array}$ & $\begin{array}{r}u_{i} \\
(\%)\end{array}$ & $\begin{array}{c}D_{s} \\
\left(\mathrm{~g} / \mathrm{cm}^{3}\right) \\
\end{array}$ & $\begin{array}{r}u_{f} \\
(\%) \\
\end{array}$ & $\begin{array}{c}P E \\
\left(\mathrm{kgf} / \mathrm{cm}^{2}\right)\end{array}$ \\
\hline 02 & 40.68 & 0,90 & 1,20 & 41,60 & 4,23 \\
\hline 11 & 13,55 & 0,90 & 1,20 & 89,60 & 3,46 \\
\hline 06 & 28,26 & 0,90 & 1,18 & 38,60 & 3,72 \\
\hline 05 & 27,78 & 0,90 & 1,20 & 60,30 & 5,45 \\
\hline 14 & 16,93 & 0,90 & 1,18 & 72,50 & 4,23 \\
\hline 12 & 19,52 & 0,90 & 1,19 & 94,40 & 6,19 \\
\hline 16 & 10,23 & 0,90 & 1,20 & 69,30 & 5,42 \\
\hline 17 & 18,12 & 0,90 . & 1,18 & 72,54 & 4,51 \\
\hline 18 & 24,95 & 0,80 & 1,20 & 43,20 & 4,53 \\
\hline 21 & 37,11 & 0,80 & 1,19 & 51,80 & 4,94 \\
\hline 23 & 13,67 & 0,80 & 1,19 & 74,60 & 4,38 \\
\hline 24 & 12,89 & 0,80 & 1,18 & 65,30 & 4,69 \\
\hline 25 & 19,57 & 0,80 & 1,18 & 55,40 & 4.02 \\
\hline 26 & 16,96 & 0,80 & 1,19 & 55,60 & 5,27 \\
\hline$A-M$ & 20,00 & 0,80 & 1,19 & 56,80 & 5,30 \\
\hline$B-M$ & 15,00 & 0,80 & 1,18 & 60,00 & 3,82 \\
\hline$D-M$ & 25,00 & 0,80 & 1,18 & 35,80 & 4,13 \\
\hline$E-M$ & 23,10 & 0,80 & 1,20 & 43,20 & 5,02 \\
\hline$F-M$ & 35,00 & 0,80 & 1,19 & 51,90 & 4,69 \\
\hline$H-M$ & 30,00 & 0,80 & 1,20 & 47,20 & 5,50 \\
\hline$J-M$ & 35,00 & 0,80 & 1,18 & 45,50 & 5,35 \\
\hline$M-M$ & 25,00 & 0,80 & 1,19 & 54,70 & 5,40 \\
\hline$N-M$ & 30,00 & 0,80 & 1,19 & 46,20 & 5,55 \\
\hline $40-M D$ & 3,00 & 0,63 & 1,19 & 105,34 & 3,57 \\
\hline $41-M D$ & 7,00 & 0,63 & 1,19 & 104,20 & 5,20 \\
\hline $43-M D$ & 7,00 & 0,63 & 1,18 & 80,86 & 3,11 \\
\hline
\end{tabular}




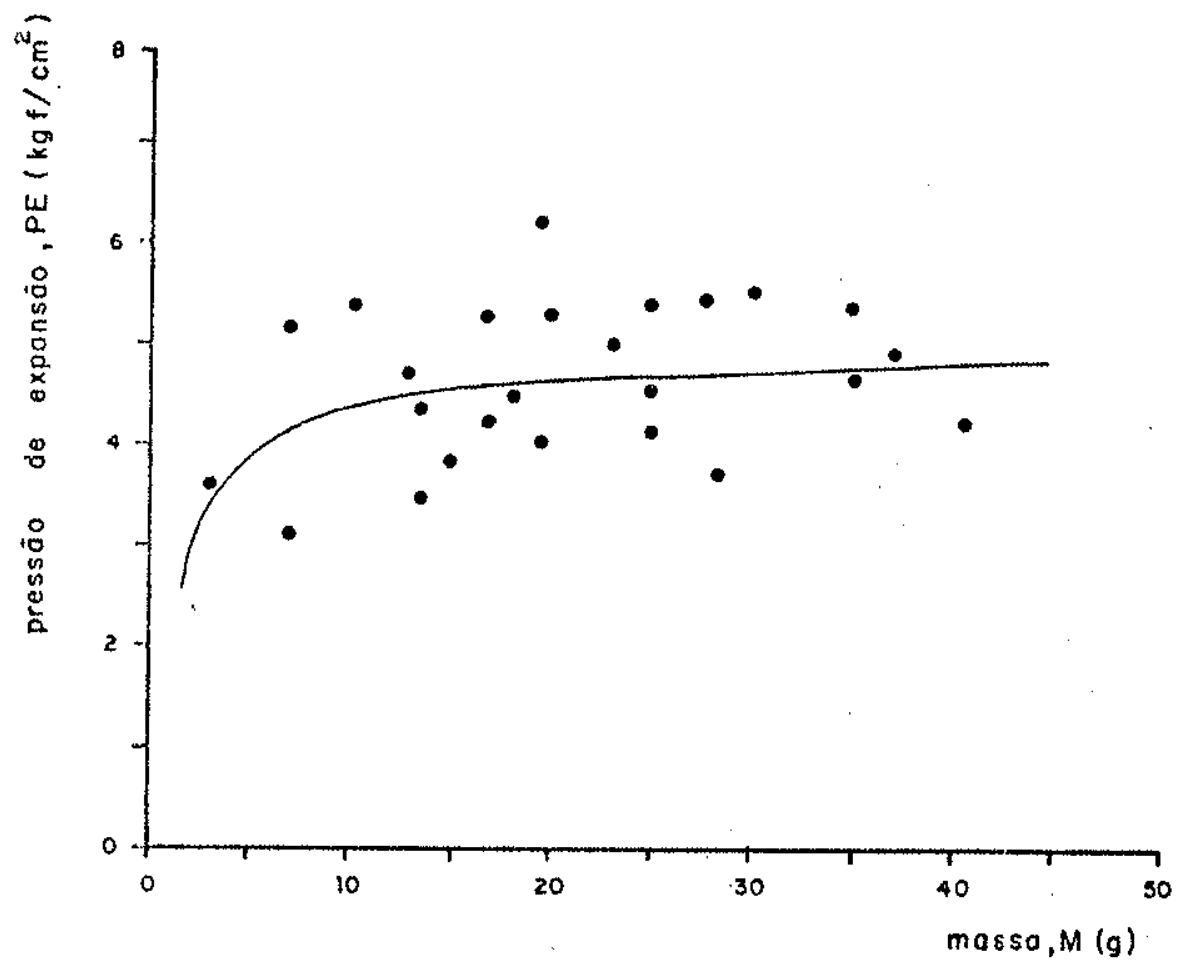

Figura 10 - Distribuição dos valores de pressão de expansão em função dos de massa, para densidades secas entre $1,18 \mathrm{e} 1,20 \mathrm{~g} / \mathrm{cm}^{3}$.

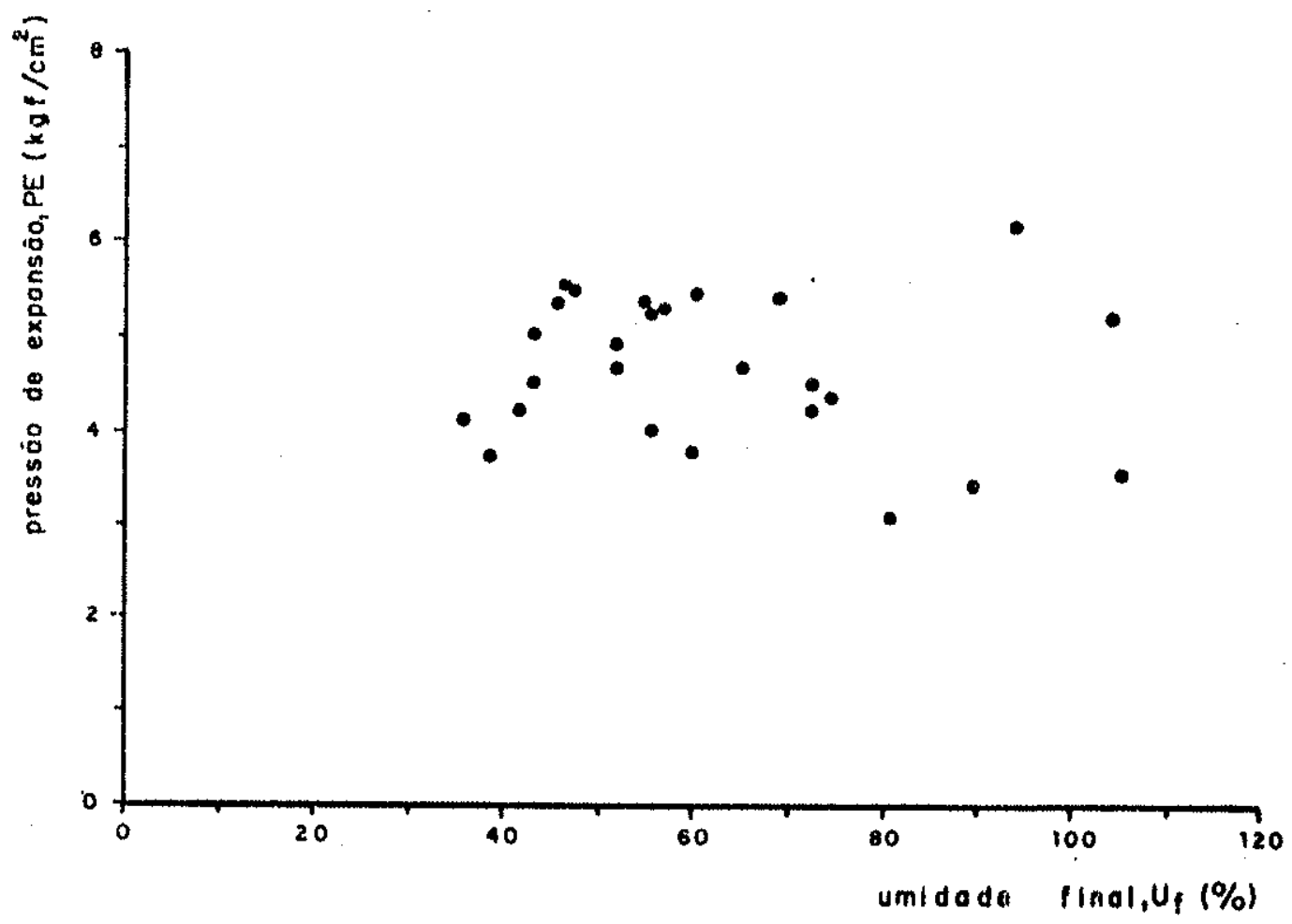

Figura 11 - Distribuição dos valores de pressão de expansão' em função dos de 3 umidade final, para densidades secas entre $1,18 \mathrm{e} 1,20 \mathrm{~g} / \mathrm{cm}^{3}$. 


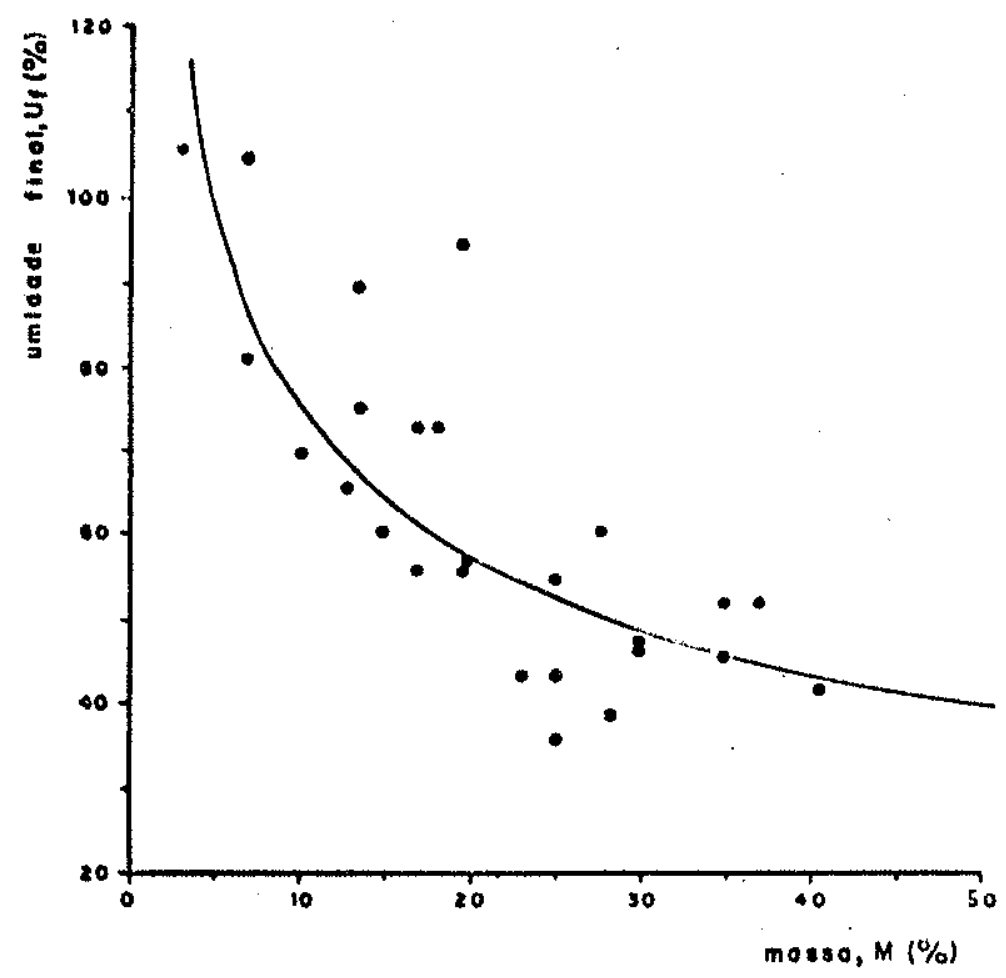

Figura 12 - Distribuição dos valores de umida de final em função dos de massa, ${ }_{3}$ para densidă des secas entre 1,18 e $1,19 \mathrm{~g} / \mathrm{cm}^{3}$.

Tabela 8 - Resultados da verificação da in fluência da densidade seca na pressão de expansão

\begin{tabular}{|c|c|c|c|c|c|}
\hline $\begin{array}{c}C P \\
(n p)\end{array}$ & $\begin{array}{l}10 \\
(9)\end{array}$ & $\begin{array}{l}u_{1} \\
(x)\end{array}$ & $\left(\mathrm{g} / \mathrm{cm}^{3}\right)$ & $\begin{array}{l}u_{f} \\
(x)\end{array}$ & $\begin{array}{c}P E \\
\left(\mathrm{kgf} / \mathrm{cm}^{2}\right)\end{array}$ \\
\hline 30 & 30 & 0,80 & 0,98 & 56,20 & 1,88 \\
\hline 10 & 30 & 0.80 & 0,99 & 48,20 & 1,63 \\
\hline 50 & 30 & 0,80 & 0,99 & 58,00 & 1,67 \\
\hline 20 & 30 & 0.80 & 1,00 & 57,10 & 1,73 \\
\hline LH & 30 & 0.80 & 1,15 & 54,60 & 5,40 \\
\hline NH & 30 & 0,80 & 1,19 & 46,20 & 5,55 \\
\hline 10 & 30 & 0,80 & 1,20 & 79.80 & 5,22 \\
\hline 80 & 30 & 0,80 & 1,20 & 38,10 & 4,33 \\
\hline 90 & 30 & 0,80 & 1,20 & 36,80 & 5.25 \\
\hline HM & 30 & 0,80 & 1,20 & 47,20 & 5,50 \\
\hline GD & 30 & 0,80 & 1,21 & 49,90 & 5,30 \\
\hline 70 & 30 & 0,80 & 1,21 & 38,70 & 6,06 \\
\hline 270 & 30 & 0.80 & 1,26 & 45,62 & 7,44 \\
\hline 220 & 30 & 0,60 & 1,30 & 50,13 & 7,71 \\
\hline 250 & 30 & 0.32 & 1,31 & 45,36 & 7,28 \\
\hline 240 & 30 & 0,30 & 1,34 & 44,14 & 7,28 \\
\hline
\end{tabular}




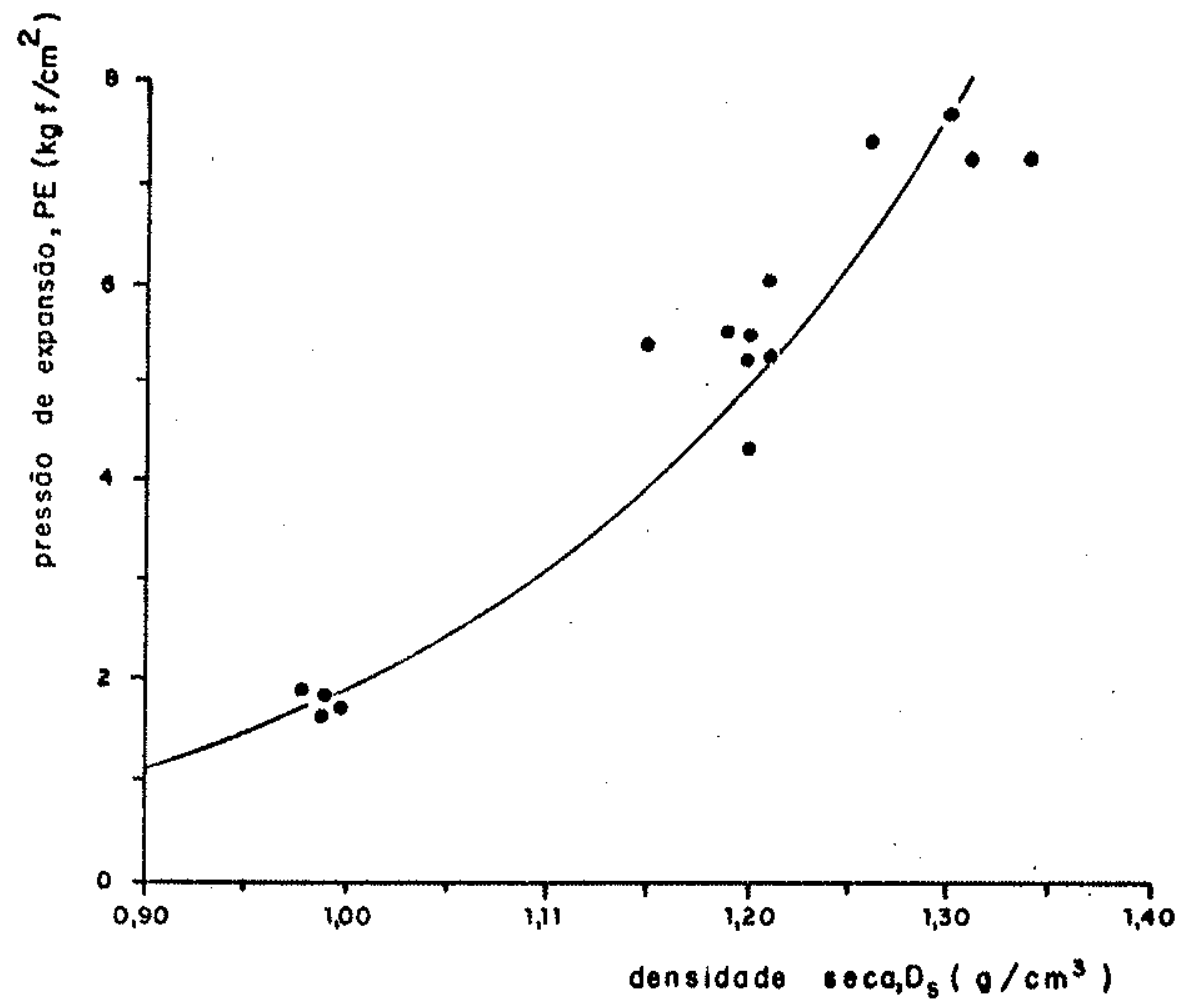

Figura 13 - Diștribuição dos valores de pressão de ex pansão em função dos de densidade seca, para massas ${ }^{\top}$ iguais a $30 \mathrm{~g}$.

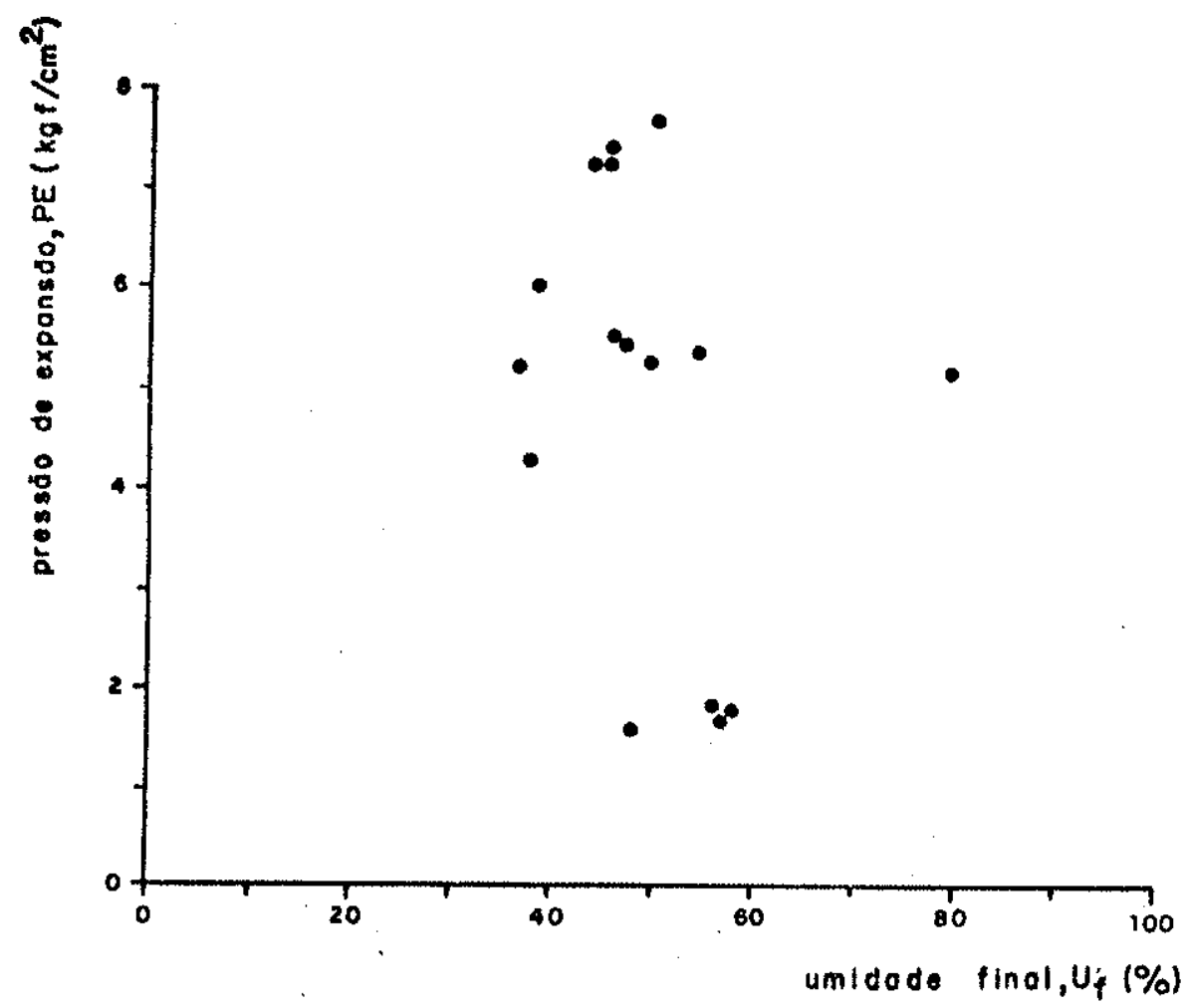

Figura 14 - Distribuição dos valores de pressão de expansão em função dos de umidade final, para massas iguais a $30 \mathrm{~g}$. 


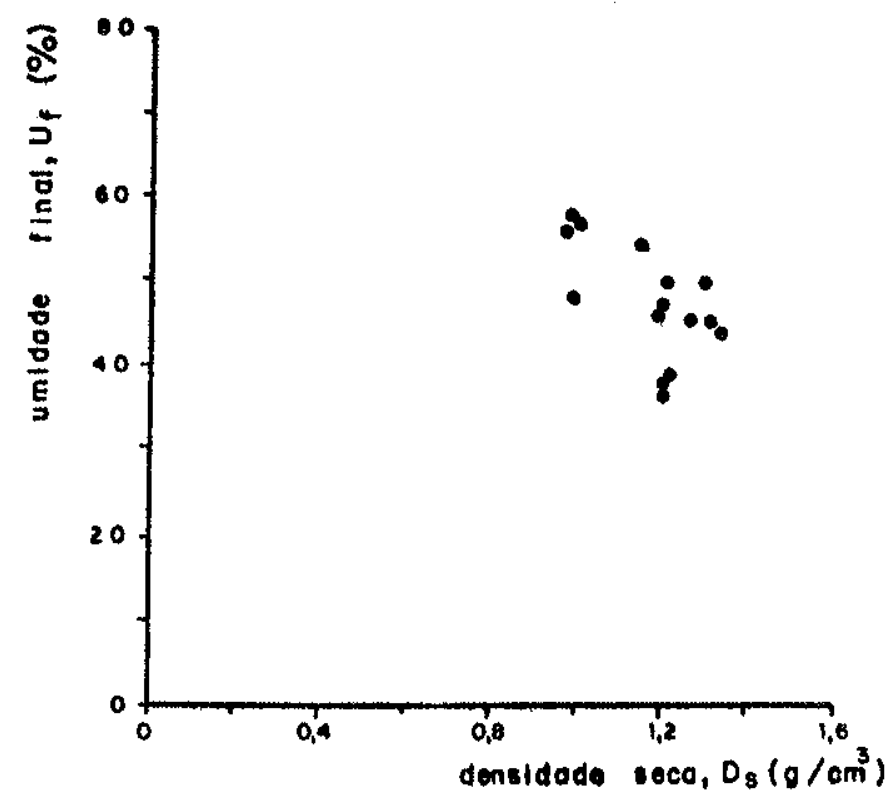

Figura 15 - Distribuição dos valores de umidade final em função dos de densidade seca, para massas iguais a $30 \mathrm{~g}$.

Tabela 9 - Resultados da verificação da influência da umida de inicial na pressão de expansão, para massas iguais a $30 \bar{g}$.

\begin{tabular}{|c|c|c|c|c|}
\hline $\begin{array}{c}\text { CP } \\
(\mathrm{n} Q)\end{array}$ & $\begin{array}{c}u_{i} \\
(x)\end{array}$ & $\begin{array}{c}0_{s_{3}} \\
\left(g / \mathrm{cm}^{3}\right)\end{array}$ & $\begin{array}{c}u_{f} \\
(x)\end{array}$ & $\begin{array}{c}P E \\
\left(\mathrm{~kg} f / \mathrm{cm}^{2}\right)\end{array}$ \\
\hline$V H-1$ & 6,20 & 1,18 & 36,13 & 6,21 \\
$V H-3$ & 8,43 & 1,19 & 37,57 & 5,58 \\
$V H-4$ & 11,04 & 1,18 & 36,49 & 4,48 \\
$V H-5$ & 14,37 & 1,18 & 36,52 & 5,23 \\
$V H-7$ & 17,72 & 1,18 & 35,78 & 4,58 \\
$V H-6$ & 19,37 & 1,18 & 52,65 & 2,70 \\
$V H-8$ & 22,52 & 1,19 & 36,21 & 4,38 \\
$V H-2$ & 28,48 & 1,18 & 45,13 & 3,31 \\
\hline
\end{tabular}




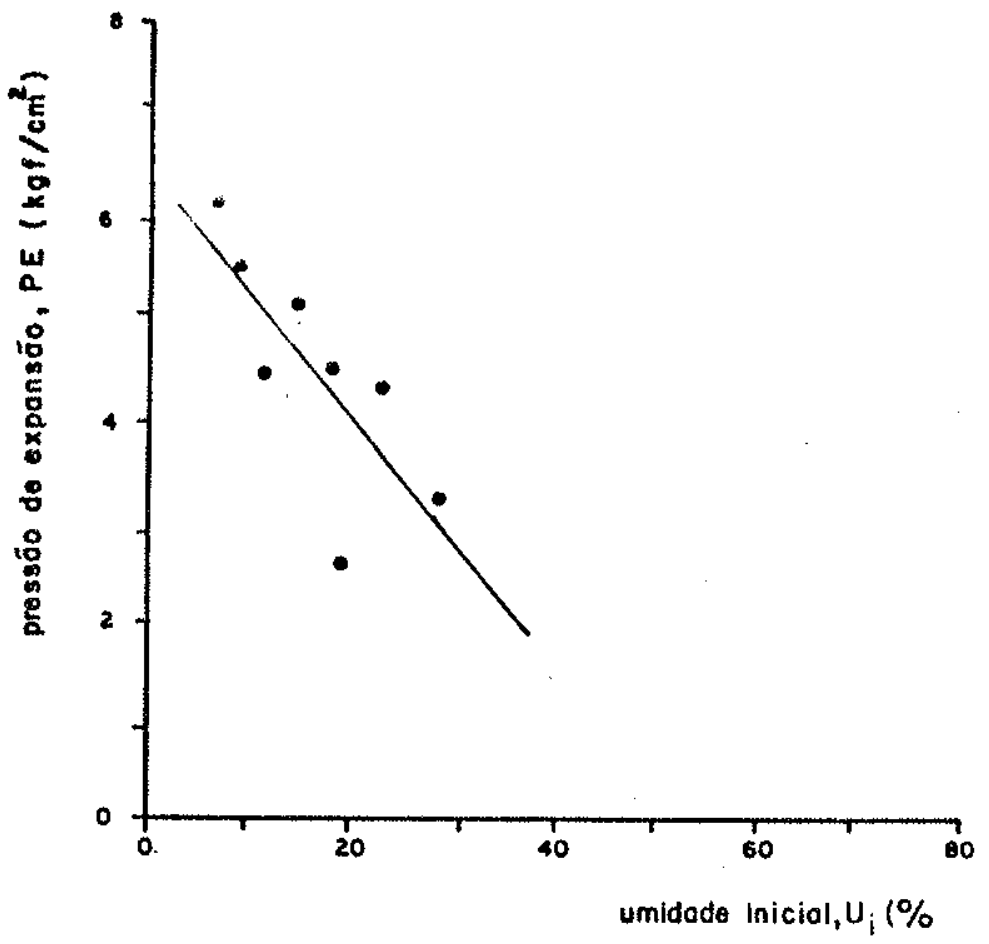

Figura 16 - Distribuição dos valores de pressão de expansão em função dos de umidade inicial para densidades secas entre 1,18 e 1,19' $\mathrm{g} / \mathrm{cm}^{3}$ e massas iguais a $30 \mathrm{~g}$.

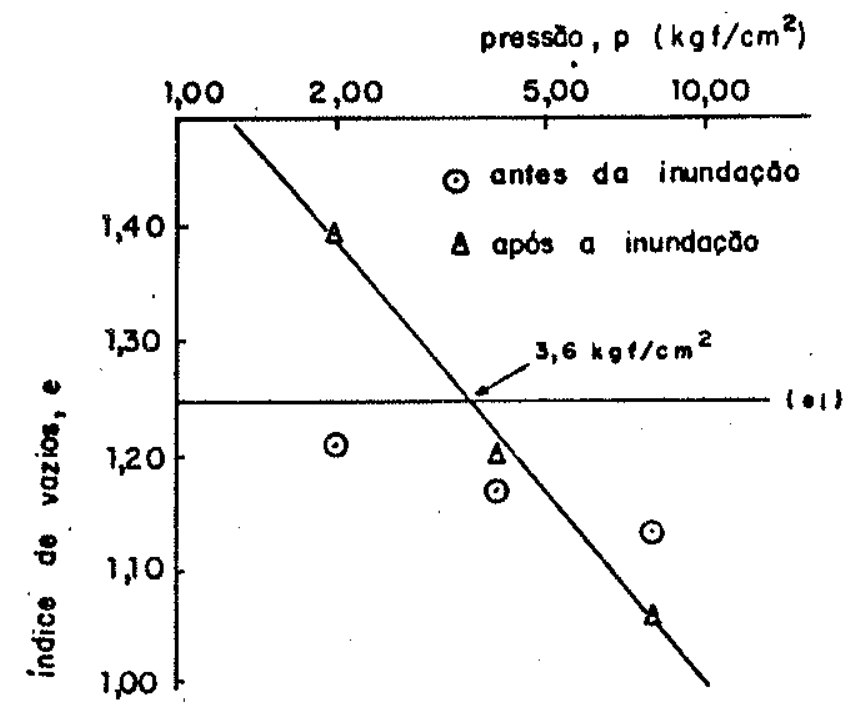

Figura 17 - Distribuição dos resultados do ensaio de pressão de expansão, de acordo com a modalidade no 1 , sobre a amostra de argila Volclay-SPV ( curva $e=f(\log p)$ 
Tabela 10 - Resultados dos ensaios de pressão de expansão sobre arenitos.

\begin{tabular}{|c|c|c|c|c|}
\hline \multirow{2}{*}{$\begin{array}{c}\text { Allustra } \\
\text { (nQ) }\end{array}$} & $U_{i}$ & $\dot{D}_{S}$ & \multicolumn{2}{|c|}{$P E\left(\mathrm{kgf} / \mathrm{cm}^{2}\right)$} \\
\cline { 4 - 5 } & $(\%)$ & $\left(\mathrm{g} / \mathrm{cm}^{3}\right)$ & $(1)$ & $(2)$ \\
\hline 01 & 3,6 & 1,96 & 4,88 & 0,59 \\
02 & 7,0 & 1,89 & 3,13 & 2,60 \\
03 & 6,0 & 1,87 & 5,20 & 1,85 \\
04 & 8,9 & 1,85 & 6,60 & 3,10 \\
\hline
\end{tabular}

Nota: (1) - Este trabalho

(2) - Fleury (1978).

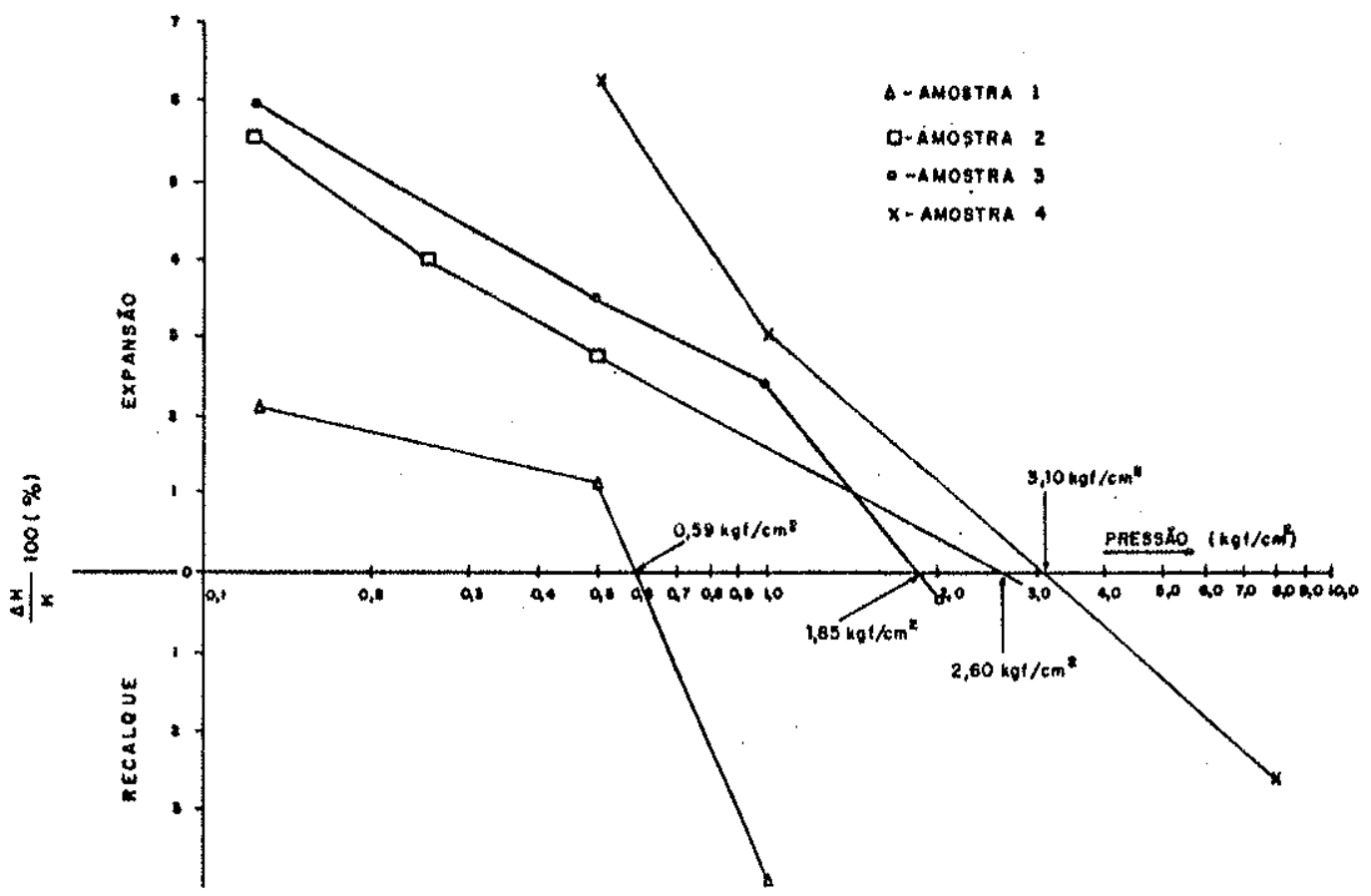

Figura 18 - Distribuição dos resultados do ensaio de pressão de expansão, segundo a modalidade nọ 2, sobre amostras de arenitos (curvas $\Delta H / H \times 100=f(\log p)$. Modificado de Fleury (1978). 


\section{CONCLUSOES}

1) a amostra de argila Volclay-SPV revelou-se ligeiramente mais silicasa e ligelramente menos aluminosa que a utilizada por Zandonadi (1972).

2) a capacidade de troca de cátions da argila Volclay - SPV $(70,3 \mathrm{mEq} / 100 \mathrm{~g}) \bar{e}$ inferior à faixa de valores encontrada na 1 teratura $(80-100 \mathrm{mEq} / 100 \mathrm{~g})$.

3) os cátions trocāveis predominantes da argila Volc laymSPV são sōdio, cālcio e magnēsio, nesta ordem.

4) o argilo-mineral predominante na argila Volclay-SPV $\vec{e}$ uma esmectita; ilita ocorre muito subsidiariamente.

5) as dimensões das particulas predominam na faixa menor que $0,004 \mathrm{~mm}(4 \mu \mathrm{m}): 90,79 \%$.

6) a argila Volclay-SPV apresenta alto valor para o limite de 1 iquidez (570\%); seu indice de plasticidade $\vec{e}$, tambëm, eleva do $(525 \%)$, mas encontra-se na faixa esperada para uma esmectita, de acordo com dados da literatura.

7) o peso especifico real da argila $V_{01 c l a y-S P V} \bar{e} 2,67 \mathrm{~g} / \mathrm{cm}^{3}$ e encontra-se na faixa esperada para uma montmorilonita, de acordo com dados da literatura.

8) a argila Volclay-SPV mostrou-se acentuadamente expansiva, a julgar pelo resultado apresentado no ensaio de expansão livre:26,5ml.

9) houve dispersão de valores de densidades secas no pro cesso de consolidação a uma pressão constante; a maior frequência de densidades situou-se entre 1,18 e $1,20 \mathrm{~g} / \mathrm{cm}^{3}$.

10) a massa influiu na pressão de expansão; ou seja, ã medi da que as massas aumentaram, aumentaram as pressões de expansão; a influéncia começou a decrescer a partir de $15 \mathrm{~g}$.

11) a umidade final não foi correlacionävel com a pressão de expansão, mas foi correlacionävel com a massa na forma de uma potência negativa, ou seja, quanto menor a massa, maior foi a umidade final.

12) a densidade seca foi correlacionāvel com a pressão de 
expansão de uma forma potencial positiva; na faixa estudada, en tretanto, pode ser considerada como mantendo uma correlação 1inear positiva, ou seja, quanto major a densidade seca, maior foi a pressão de expansão. final.

13) a densidade seca não foi correlacionävel com a umidade

14j a umidade inicial foi correlacionāvel com a pressäo de expansão de uma forma linear negativa, ou seja, quanto menor a umidade inicial, maior foi a pressão de expansão.

15) no mëtodo "a volume constante" os valores de pressão de expansão foram maiores que os obtidos pelo método convencional.

16) o mëtodo convencional è mais trabalhoso, mais demorado e menos exato que o "a volume constante".

17) a aparelhagem usada neste estudo, apesar de mais comple $x a$ na sua concepção e construção, permite a realização de ensaios de modo mais simples e mais rāpido, e fornece resultados mais exatos.

18) o mëtodo "a volume constante", com o equipamento utilizado neste estudo, permite a obtenção do valor da pressão de ex pansão diretamente; isto permite, opcionalmente, um maior nümero de ensaios para determinação da pressão de expansão de um ma terial, em menor espaço de tempo.

19) por ser automātico e simples, o equipamento usado neste estudo permite a realização de ensajos a custos mais baixos que os convencionais.

20) a julgar pelos resultados alcançados neste estudo, o me todo de ensaio "a volume constante", com o sistema de monitoração automätica, mostrou melhor desempenho que o mëtodo e o processo convencionais escolhidos para comparação. Uma corrobora ção desta conclusão, contudo, poderä ser atingida com a realiza ção de um maior nūmero de ensaios e com uma variedade maior de amostras, pelo sistema convencional, em investigações futuras. 


\section{AGRADEC IMENTOS}

Desejamos expressar nossos sinceros agradecimentos:

Ao Instituto de Pesquisas Tecnolögicas do Estado de Säo Paulo S.A., que, atravēs da Divisão de Minas e Geologia Aplicada (DMGA), forneceu-nos todo apoio material e humano necessärio à execução deste trabalho.

Ao Professor Doutor Josē Eduardo Siqueira Farjallat, que idealizou o instrumental utilizado e forneceu-nos atenciosa e permanente orientação durante todo o desenvolvimento deste trabatho.

Aos Geölogos Nicolau Palı e Fäbio Taioli e ao Engenheiro Alvaro B. Gabrielli, pelo planejamento e construção do sistema de monitoração automätica dos ensaios e pelo constante interesse demonstrado durante todas as fases deste trabalho.

Ao Geölogo Jorge K. Yamamoto, pelas valiosas sugestöes a presentadas no tratamento estatístico dos dados e pelo apoio, incentivo e interesse manifestados durante toda a parte experimental deste trabalho.

Ao Engenheiro Josē Luis R. Rocha, pela execução dos ensaios pelo processo convencional e pelas valiosas sugestões apresenta das no inicio deste estudo.

A Engenheira Cassia de Assis Fleury, pelo incentivo dado a este estudo e pelo fornecimento de valiosas informações referen tes a sua experiencia com solos expansivos.

Ao Professor Doutor Josē Vicente Valarelli, de quem tive a honra de receber as primeiras orientações no curso de pós-Gra duação do IGUSP, pelo incentivo na condução deste estudo.

Ao Geōlogo Jäiro de Sant'Anna Taddeo, pelo apoio e atenção sempre presentes e pela revisão criteriosa dos manuscritos.

Ao Professor Doutor Riuti Yoshida, que, quando colega do $A$ grupamento de Petrologia da DMGA, muito nos incentivou à pesqui sa no campo da mineralogia das argilas aplicada e pelas suges tões de roteiro para o trabalho que ora se concretiza.

Ao Geōlogo Saul B. Suslick e ao Estatistico José Alberto Quintanilha, pelo auxílio e sugestões no tratamento estatistico dos resultados. 
Aos Geölogos Eleno de Paula Rodrigues, Atsushi Suemitsu, Luiz Geraldo Caruso. Maria Cristina de Morais e Miriam Cruxēn B. de 01 iveira, que, como colegas de trabalho, deram-nos todo o apoio e incentivos necessärios para este estudo.

A Engenheira Eda de Freitas Quadros, pelas valiosas criticas apresentadas na elaboração do texto deste trabalho.

Ao Químico Industrial Amilton G. de Andrade, pela preparação cuidadosa das amostras e pela atenciosa condu\&ão dos traba Ihos laboratoriais.

Ao técnico Joaquim Ireno, que, sempre com muita dedicação, cuidou da construção e manutenção dos equipamentos utilizados nos ensaios.

A Estagiāria-aluna Sandra Noemi Finzi, pelas importantes discussões mantidas sobre aspectos físico-químicos da expansão.

Ao José Roberto Vieira, pela confecção dos gräficos; e ao Arturo Prieto, pela elaboração dos desenhos.

Aos Técnicos Andrē Luiz M. da Silva, Benito 0. Rocha, Elaj ne V. dos Santos, Expedito D. Amorim, Fābio C. de Queiroz, Jilson Cardoso, Josë Antonio M. dos Santos, Luiz Martins, Nilson. de Paula, Paulo Mori e Sonia A.R. Lopes, que, direta ou indiretamente, forneceram as condições laboratoriais necessärias para a execução das diferentes etapas deste trabalho.

A Bibliotecāria Marcia M. Saad, pelo valioso auxilio na elaboração das referēncias bibliogräficas deste trabalho.

As Secretārias Dagmar Sartini, Maria de Lourdes Fonseca e Märcia A.P. Maröstica, pelos serviços de datilografia. 
BIBLIOGRAFIA

AGARWAL, K.P. e SHARMA S.C. - 1974 - A method tor measuring swelling pressure for an expansive soil. In: CONFERENCE ON EXPANSIVE SOILS, 39, Halfa, 1973. Anals...Halfa.v.1, p.155-159. AITCHISON, G.D. e MARTIN, R. - 1974 - A membrane oedometer for complex stress-path studies in expansive clays. In: INTERNATIONAL CONFERENCE ON EXPANSIVE SOILS, 30, Haifa, 1973. Anais....Haifa. V.1, p.161-167.

ALPAN, I. - 1957 - An apparatus for measuring the Swe 11 ing pressure in expansive soils. In: INTERNATIONAL CONFERENCE ON SOIL MECHANICS AND FOUNDATION ENGINEERING, 40, Paris, 1957. Anais...Paris.p.3-5.

AMERICAN SOCIETY FOR TESTING AND MATERIALS - 1970 - Standard specification for wire-cloth sieves for testing purposes. Philadelphia. (ASTM ELL-70).

ASSOCIAÇAO BRASILEIRA DE NORMAS TECNICAS - ABNT - 1977 - Deter minação da massa especîfica dos grãos de solos. Rio de Ja neiro.5.p. (ABNT MB-28).

ASSOCIAÇAO BRASILEIRA DE NORMAS TECNICAS - ABNT - 1977 - Deter minação do limite de liquidez de solos. Rio de Janeiro.6.p. (ABNT MB-30).

ASSOCIAÇAO BRASILEIRA DE NORMAS TECNICAS - ABNT - 1977 - Deter minação do limite de plasticidade e do indice de plasticida de de solos. Rio de Janeiro.4.p. (ABNT MB-31).

BASU, R. e ARULANANDAN, K. - 1974 - A new approach to the identification of swell potential of soils. In: INTERNATIUNAL CONFERENCE ON EXPANSIVE SOILS, 30, Haifa, 1973. Anais... Haifa. V.1, p.1-11.

BJERRUM, L.; BREKKE, T.L.; MOUN, J.; SELMER-OLSEN, R. - 1964 Some Norwegion studies and experiences with swelling materials in rock gouges. 0s 10, Geothecnical Institute.9p. (Geothecnical Institute, publication 57 ).

BRACKLEY, I.J.A. - 1974 - Swell pressure and free swell in a compacted clay. In: INTERNATIONAL CONFERENCE ON EXPANSIVE 
SOILS, 30, Haifa, 1973. Anais...Haifa.v.1, p.169-176. BREKKE, T.L. - 1975 - On the measurement of the relative potential swellability of hidrotermal montmorillonite clay from joints and faults in pre-Cambrian and paleozoic in Norway. International Journal of Rock Mechanics and Mining Sciences, 0xford, 2:156-165. CAPRARIIS, P.; LINDELMANN, R.; COLLINS, C.M. - A method for determining optimum sample size in species diversity studies. Journal of the International Association for Matematical Geology. New York, 8(5):575-581.

CAPUTO, H.P. - 1974 - Indices físicos. In: Mecãnica dos Solos e suas aplicacões. 3.ed. Rio de Janeiro, Livros Técnicos e Cien tificos. v. 1, p.40-55.

CHEN, F.H. - 1974 - The basic physical property of expansive soils. In: INTERNATIONAL CONFERENCE ON EXPANSIVE SOILS, 30, Haifa; 1973. Anais...Haifa.v.1, p.17-25.

CHEN, F.H. - 1975 - Foundations on expansive soils. Developments in Geotechical Engineering. Amsterdam. Elsevier, 12:280.

CHU, T.H.; MOU, C.H. - 1974 - Volume change characteristics of expansive soils determined by controlled suction testd. In: INTERNATIONAL CONFERENCE ON EXPANSIVE SOILS, 3\%, Haifa, 1973. Anais...Haifa.v.1, p.177-185.

DE LAMBALLERIE, G.N. - 1962 - Contribution a l'ëtude des phénomēnes de gonflement accompagnat l'hidration des argiles compactes. Tolouse. 140p. (Tese de Doutorado. Universidade de Tolouse). DIDIER, G. - 1972 - Gonflement Cristallin et macroscopique des montmorillonites-Sa prevision. Lyon.110p. (Tese de Doutorado. Universidade Claud Bernard, Lyon).

DIDIER, G. - 1974 - Swelling pressures of sojls-Experimental device field of utilization. In: INTERNATIONAL CONFERENCE ON EXPANSIVE SOILS, 39, Haifa, 1973. Anais...Haifa. p.187-193.

DUNCAN, N.; DUNNE, M.H.; PETTY, S. - 1968 - Swelling characteristcs of rock. Water Power, Londres, p.185-192.

ESCARIO, V.; SAEZ, J. - 1974 - Measurement of the properties of 
swelling and colapsing soils under controlles suction. In: INTERNATIONAL CONFERENCE ON EXPANSIVE SOILS, 39, Haifa, 1973. Anais...Haifa.v.1, p.195-200.

FARJALLAT, J.E.S. - 1969 - Observações sobre desagregação do ba salto compacto utilizado no enrocamento do aterro da ponte do Rio sucuriu. In: SEMANA PAULISTA DE GEOLOGIA APLICADA, 1a São Paulo, 1969. Anais...São Paulo.v.3, p.VI-1-VI-5.

FARJALLAT, J.E.S. - 1971 - Estudos experimentais sobre degradação de rochas basālticas - Basalto da barragem de CapivariRio Paranapanema. São Paulo. 125p. (Tese de Doutorado. Insti tuto de Geociências e Astronomia da USP).

Fl. EURY, C.A. - 1978 - Estudo do comportamento de argilas expansivas de ocorréncia no Estado de São Paulo. São Paulo. 31 . (Relatörio FAPESP - Processo nọ 76/0394).

FRAZAO, E.B.; FARJALLAT, J.E.S.; PALM, N. - 1978 - Applications of a simple servo-controlled device in the measurement of swelling pressure of rocks and minerals. In: INTERNATIONAL CONGRESS OF ENGINEERING GEOLOGY, 39, Madrid, 1978. Anais...Madrid.v.2, section IV, p.132-136.

FRAZAO, E.B.; MIOTO, J.A.; SANTOS, A.R. - 1976 - 0 fenōmeno da desagregação superficial em rochas argilosas-Sua implicação na estabilidade de taludes viärios. In: CONGRESSO BRASILEIRO DE GEOLOGIA DE ENGENHARIA, 19, Rio de Janeiro, 1976. Anais... São PaU10, ABGE.V.1, P.211-228.

GRAFT-JOHNSON, J.W.S.; BHATIA, H.A.; YEBOAH, S.L. - 1974 - SOme swelling characteristics of the marine shale of Accra. In: INTERNATIONAL CONFERENCE ON EXPANSIVE SOILS, 39, Haifa, 1973. Anais...Haifa.v.1, p.55-63.

GRIM, R.E. - 1962 - Clay mineralogy in relation to the engineering properties of clay materials. In: APPLIED CLAY MINERALOGY. New York, Mc Graw Hill, p.204-277 (International Series in the Earth and Planetary Sciences).

GRIM, R.E. - 1968 - Miscellaneous Properties. In: CLAY MINERALOGY. $2^{a}$ ed. New York, Mac Graw Hi11. p.434-478 (International Series 
in the Earth and Planetary Sciences).

HORTA DA SILVA, J.A. - 1971 - Geologia e comportamento geotēcni co da argila expansiva de Cazenga-Luanda. In: REGIONAL CONFERENCE FOR AFRICA ON SOIL MECHANICS FOUNDATION ENGINEERING, 50, Luanda, 1971. Anais...Luanda. p. 1-30-1-40.

HORTA DA SILVA, J.A. - 1975 - Solos expansivos-comportamento, i dentificação, quantificação da instabilidade volumētrica e projectos de fundações, parte I. Geotecnia, Lisboa, 13:29-63.

INTERNATIONAL SOCIETY FOR ROCK MECHANICS - 1971 - Suggested methods for determining the slaking, swelling, porosity, density and related rock index properties, Lisboa. ISRM Comission on Standardization on laboratory and field tests. $45 \mathrm{p}$.

KARALIS, T.K. - 1971 - Etude expērimental des phēnomenès de dëformation et d'humidification d'une argile gonflante, Tolouse, Universidade Paul Sabatier. $161 \mathrm{p}$. (Tese de Doutoramento). KASSIF, G.; BAKER, R.; OVADIA, Y. - 1974 - Swell pressure relationships at constant suction changes. In: SIMPOSIO INTER NACIONAL SOBRE SOLOS EXPANSIVOS, 3, Haifa, 1974. Anais...p. $201-202$.

KAZDA, J. - 1974 - Study of the swelling pressure of soils. In: SIMPOSIO INTERNACIONAL EM MECANICA DOS SOLOS E ENGENHARIA DE FUNDAÇOES, 4, Paris, 1974. Anais...p.140-142.

KUL'CHITSKIJ, L.I. - 1970 - Application d'un modele osmotique a l'ètude de la compressibilitēet du gonflement des argiles saturēes. Paris, LCP Ch., Service de Documentation, Cooperation Techniques et Scientifique Franco-Sovietique en Mecanique de Sols. 17p. (Tradução 72 T 30).

KULKARNI, S.K.; KATTI, R.K. - 1974 - A micro-particle and microanchor approach to mechanics of swelling soil media. In: SIMPOSIO INTERNACIONAL SOBRE SOLOS EXPANSIVOS, 3, Haifa, 1974. Anais...P. 43-52.

LAMBE, T.W. - 1958 - The structure of compacted clay. Journal of the Soil Mechanics and Foundation Division (1654): 1-33. 
MURAYAMA, S.; YAGI, N. - 1966 - Swelling of mudstone due to sucking of water. In: CONGRESSO INTERNACIONAL DE MECANNICA DAS ROCHAS, 10, Lisboa, 1966. Anais...v.1, p.495-498.

NASCIMENTO, U.; OLIVEIRA, R.; GRAÇA, R. - 1968 - Rock swelling test. In: INTERNATIONAL SYMPOSIUM ON ROCK MECHANICS, Madrid, 1968 .

RAVINA, I. - 1974 - Swelling of clays: Mineralogical composition and microstructure. In: SIMPOSIO INTERNACIONAL SOBRE SOLOS EX PANSIVOS, 30, Haifa, 1974. Anais...p.61-63.

RUIZ, M.D. - 1963 - Mecanismos de desagregação de rochas bas ticas semi-alteradas. São Paulo, Instituto de Pesquisas Tecnolögicas. (Publicação IPT, 696).

SATYANARAYANA, B. - 1974 - Effect of anisotropy on expansion characteristics. In: INTERNATIONAL CONFERENCE ON EXPANSIVE SOILS, 30, Haifa, 1973. Anais...Haifa.v.1, p.217-225.

SEED, H.B.; WOODWARD, R.J.; LUNDGREN, R. - 1962 - Prediction of swelling potential for compacted clays. Journal of the soil Mechanics and Foundation Division. New York, (3169): 53-87.

SKEMPTON, W. - 1953 - The colloidal "activity" of clays. In: INTERNATIONAL CONFERENCE ON SOIL MECHANICS AND FOUNDATION ENGINEERING, 30, Zurich, 1953. Anais...p.57-61.

SUGu10, K. - 1973 - Introdução à sedimentologia. São Paulo, Edgar B 1ucher. $317 \mathrm{p}$.

THENOZ, B.; FARRAH, J.; CAPDECOMME, L. - 1966 - Role des Argiles dans le comportement des roches cristallines mises au contact de 1 'eau. In: INTERNATIONAL CONGRESS ON ROCK MECHANICS, 19, Lisboa, 1966. Anais...Lisboa.v.1, p.717-719.

VIAJAYVERGIA, V.N.; GHAZZALY, 0.I. - 1974 - Prediction od swelling potential for natural clays. In: INTERNATIONAL CONFERENCE ON EXPANSIVE SOILS, 30, Haifa, 1973. Anais... Haifa. v. 1, p. 227-236.

WHITE, A.W. - 1958 - Water sorption properties of homoionic clay minerals. Urbana, Illinois State Geological Survey. 46p. il. (Illinois State Geological Survey Report of Investigation, 208). 
YOSHIDA, R. - 1972 - Contribuição ao conhecimento de características tecnológicas de materiais rochosos. São Paulo. 2v. (Tese de Doutorado. Instituto de Geociências da USP).

ZANDONADI, A.R. - 1972 - Estudo tecnológico de argilas nontroniticas brastleiras. São Paulo. 234p. (Tese de Doutorado. Insti tuto de Quĩmica da USP).

ZANDONADI, A.R.; SANTOS, P.S. - 1972 - Pressão de expansão do "Sistema argila + água" em argila montmoriloníticas provenien tes de tūneis construídos em granitos decompostos. São Pauto. p.738-757. (Relatório FAPESP - processo PTI-70/993).

ZANDONADI, A.R.; SANTOS, P.S. - 1978 - Propriedades reológicas de montmorilonitas ou esmectitas brasileiras. 25: $355-371$.

Cerâmica 